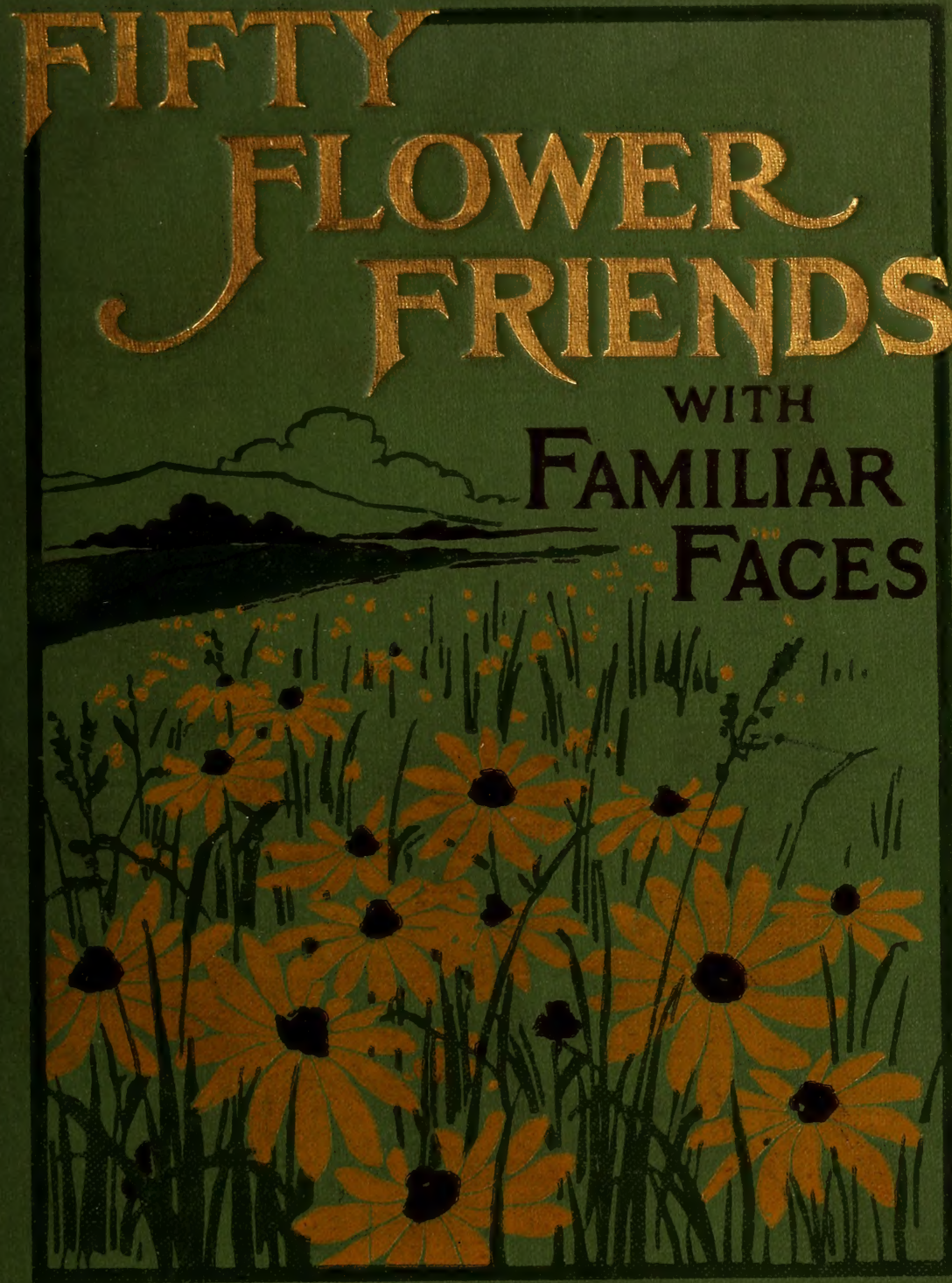

A FIELD BCOK ForBOYS AND GIRLS

EDITH DUNHAM 

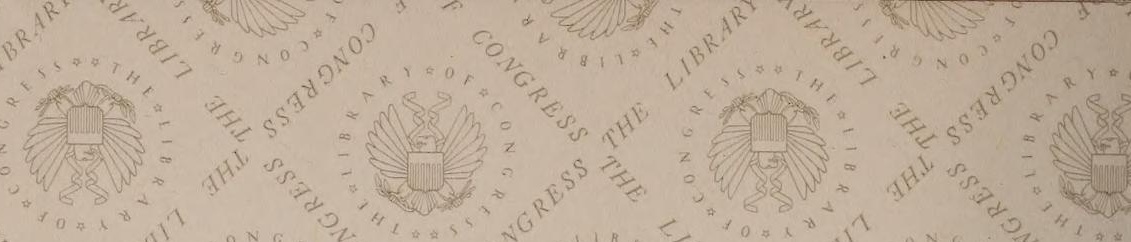
. 


\section{FIFTY FLOWER FRIENDS WITH FAMILIAR FACES}






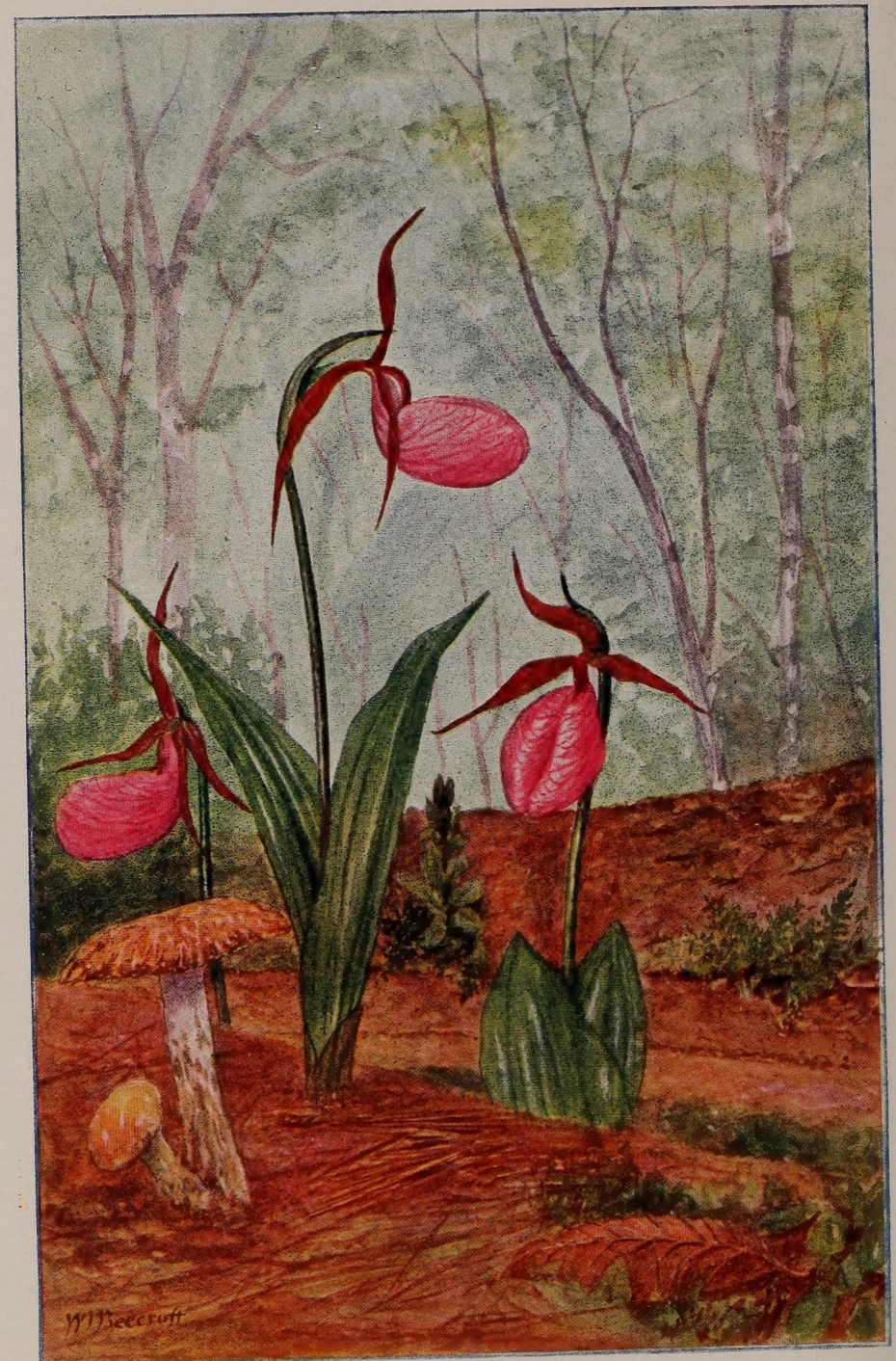

LADY'S SLIPPER 


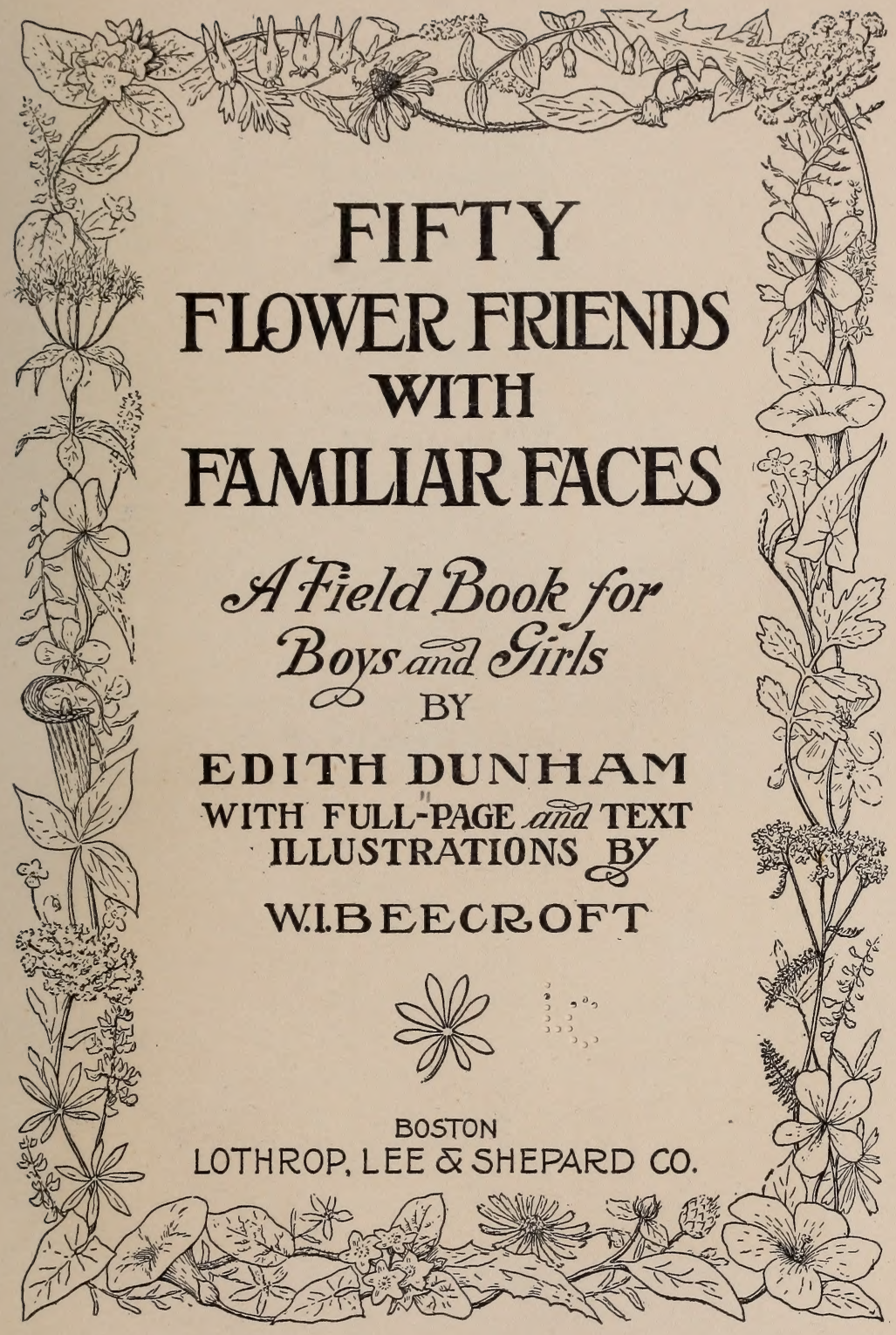




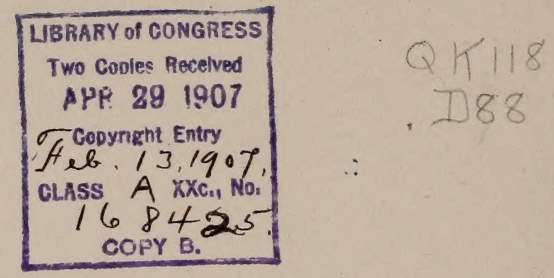

Published, April, 1907.

Copyright, 1907, by Lothrop, Lee \& Shepard Co.

All Rights Reserved.

Fifty Flower Friends.

Norboond 胭ress

J. S. Cushing \& Co. - Berwick \& Smith Co.

Norwood, Mass., U.S.A. 


\section{CONTENTS}

PAGE

INTRODUCTION • • • • • • • • 11

Dandelion (Taraxacum Taraxacum, B.\&B.; Taraxacum

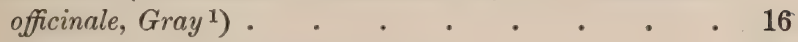

Trailing Arbutus (Epigcea repens) . . . . 22

Bluets (Houstonia carulea) . . . . . . . 28

Columbine (Aquilegia Canadensis) . . . . . $\quad$ • 32

Dutchman's Breeches (Bicuculla Cucullaria, B. \& B.;

Dicentra Cucullaria, Gray) • • • . . 38

Bird-Foot Violet (Viola pedata) . . . . . . 42

Winter Cress (Barbarea stricta, B. \& B.; Barbarea vul-

garis, Gray) . . . . . . . 46

JACK-IN-The-Pulpit (A riscema triphyllum) . . $\quad 50$

BARBerRy (Berberis vulgaris) . . . . . . 56

Pitcher Plant (Sarracenia purpurea) . . . $\quad$. 60

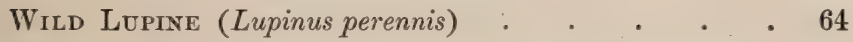

OXeYe or White Daisy (Chrysanthemum Leucanthemum) 68

Mountain Laurel (Kalmia latifolia) • • . . 74

Celandine (Chelidonium majus) • • . . $\quad$. 80

LAdy's Slipper (Cypripedium acaule) . . . . 84

Blue FlaG (Iris versicolor) • • • . • . 88

1 "B. \& B." denotes Britton and Brown as authority; "Gray" denotes Gray's Botany. 
Black-eyed Susan (Rudbeckia hirta) • . . . 94

Solomon's Seal (Polygonatum biflorum) • • . . 98

St. JoHn's Wort (Hypericum perforatum) • . . 102

Wild Orange-Red Lily (Lilium Philadelphicum) • . 106

Dogbane (Apocynum androscemifolium) . . . . 110

WAter-Lily (Castalia odorata, B. \& B.; Nymphoea odorata, Gray) . . . . . . . . 114

Fireweed (Chamcenerion angustifolium, B. \& B.; Epilobium angustifolium, Gray) • . . . 118

Milkwort (Polygala viridescens, B. \& B.; Polygala san-

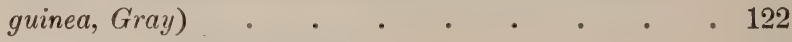

Wild Carrot (Daucus carota) . . . . . 126

Bouncing Bet (Saponaria officinalis) . . . . . 130

Wintergreen (Gaultheria procumbens) . . . . 134

Indian PIPe (Monotropa uniflora) • . . . . 138

MrLkweed (Asclepias Syriaca, B.\& B. ; Asclepias Cornuti,

Gray) . . . . . . . . . . 142

Wild Morning Glory (Convolvulus sepium) • • 148

Mullein (Verbascum Thapsus) . . . . . . 152

Butter-And-Eggs (Linaria Linaria, B. \& B.; Linaria vulgaris, Gray) . . . . . . . . 156

Pickerel-Weed (Pontederia cordata) . . . . . 160

Orange Hawkweed (Hieracium aurantiacum) . . 164

White Sweet Clover (Melilotus alba) . . ‘ . 168

YARRow (Achillea Millefolium) . . . . . . 172

White Alder (Clethra alnifolia) . . . . . 178

Knotweed (Polygonum Pennsylvanicum) • . . . . 182

Wild Mint (Mentha Canadensis) . . . . . 186

Dodder (Cuscuta Gronovii) • . . . . . 190 
Partridge Pea (Cassia Chamacrista) . . . . 194

JEWEL WeED (Impatiens biflora, B.\& B.; Impatiens fulva,

Gray) . . . . . . . . . . . . 198

Hardhack (Spircea tomentosa) . . . . . . 204

TANsY (Tanacetum vulgare) . . . . . . 210

Chicory (Cichorium Intybus) . . . . . . 214

Cardinal Flower (Lobelia cardinalis) . • . • 218

Swamp Rose Mallow (Hibiscus Moscheutos) • • 222

JoE-Pye WEed (Eupatorium purpureum) • • . 226

LAdY's Tresses (Gyrostachys cernua, B. \& B.; Spiranthes

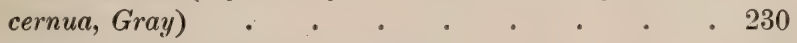

Fringed Gentian (Gentiana crinita) • • . . 236 



\section{FULL-PAGE ILLUSTRATIONS}

LAdy's Slipper (Page 84) . . . . Frontispiece

Columbine . . . . . . . . . . . 34

JACK-IN-The-PULPIT • . • . . . . $52 \sqrt{ }$

Mountain Laurel . . . . . . . $76^{\sqrt{ }}$

BLUE FlaG . . . . . . . . . $90^{\circ}$

BLACK-EYED SUSAN • • . . . . . . $96^{\circ}$

Wild Orange-Red Lily . . . . . . 108

Butter-AND-EgGs . . . . . . . . . 158

Orange Hawkweed . . . . . . . . 166

HARDHACK . . . . . . . . 206

Cardinal Flower . . . . . . . . 220

Fringed Gentian . . . . . . . . 238 



\section{INTRODUCTION}

\section{WHEN, WHERE, AND HOW?}

Wно painted the yellow buttercup

And the daisy's shining heart?

The sun, with his golden pencil

And hand of magic art?

Then, did the little cloudlets

Stoop with their misty white,

And bring a dress for the snowdrop,

And fringe for the daisy bright?

How did the pink anemone,

And the purple, find their hue?

Are they the dainty colors

Of the earliest morning dew?

And the stately scarlet lily -

Where did it catch its glow?

Over there in the gleaming west

When the sun was shining low? 
And all the buds and grasses ;

Look at their tender green:

Did ever you see such dresses

Worn by a fairy queen?

Where did the brushes come from

That daintily touched them so?

Straight, do you think, from Paradise?

Where else could they ever grow?

- Sydney Dayre.

When this book was first planned, it was the intention of the author to write simply a series of sketches which would bring before boys and girls a few flowers more or less well known, and enable them to identify the plants for themselves. In these sketches some facts about each flower were stated, but it was intended to bring out more the personality of these friends in the plant world, and the locality in which each would be found, 
than to give an actual description of the flowers. As the work grew, however, it seemed better to add an accurate description of each plant, thus making the book a practical field book, which it is hoped will be found of use to children at home or in school. If by its use the boys and girls learn to have a deeper love for our wild flowers, and a desire for better knowledge of them, with the wish to preserve them as far as possible in their native haunts, the author's hope will be fulfilled. We all know how much more enjoyable a walk through the country is if our eyes are open to the beauties of nature, to which the wild flowers contribute no small part. Who has not felt a thrill of joy at the sight of hills covered with the exquisite wild violets; or a pond dotted here and there with the 
wonderful white lilies that seem to belong to another world; or who that has seen the cardinal flower in its splendor can forget the graceful majesty of it? How much more we should enjoy the world, then, if we were alive to all its beauties and wonders! What a marvel of perfection each tiniest blossom is, each blade of grass; and yet for the most part we go through the world blindly, — seeing only the big masses of things that must of necessity arrest our attention. It is the children who, with infinite wisdom, have their eyes wide open for beauty, and minds athirst for more knowledge of the things they see. To the children who have taught me to appreciate a little more the beauties of life, I wish to express my humble gratitude.

EDITH DUNHAM.

February, 1907. 

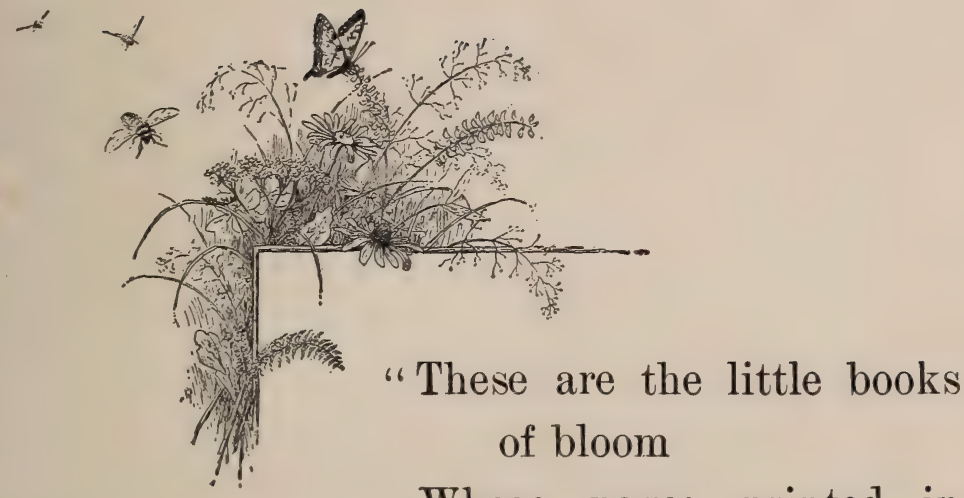
Whose pages printed in perfume,

Hold lyrics in a language known

To bees and butterflies alone." 


\section{DANDELION}

Chicory Family

CoMposite (Gray)
Taraxacum Taraxacum

Taraxacum officinale (Gray)

\section{JANUARY - DECEMBER}

Common in fields, waste and grassy places. The root is thick, deep, and bitter. The scape is erect, two to eighteen inches high. Leaves are oblong to spatulate, toothed, usually downy when young, narrowing into petioles. Flower heads are from one to two inches broad, containing many golden yellow star-shaped flowers. The bracts outside the flower head, called the involucre, are of two shapes: the inner ones long and narrow, the outer ones short and scale-like, bent outward. The akenes are greenish brown, spindle-shaped, narrowing into a thread-like tip two or three times their length, which supports the white pappus, or down. In fruiting this becomes a round mass of feathery down, which is soon scattered by the wind, taking with it the akenes containing seeds. 

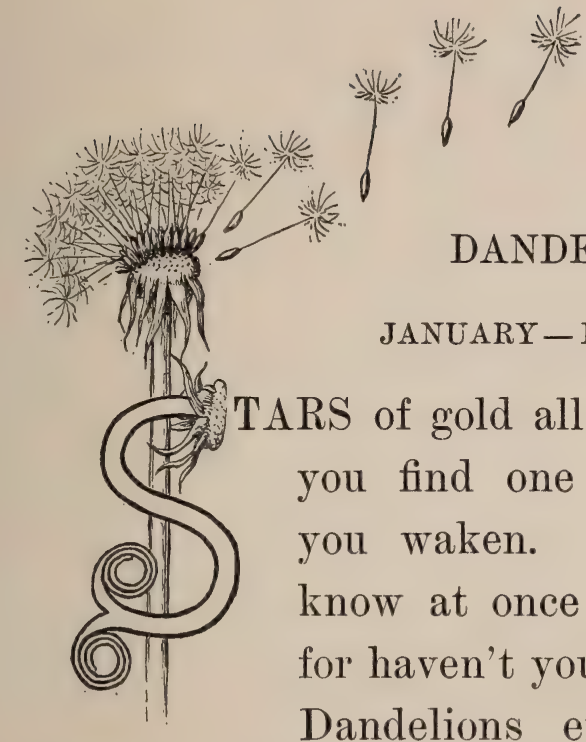

\section{DANDELION}

\section{JANUARY — DECEMBER}

TARS of gold all over the grass, you find one morning when you waken. Of course you know at once what they are, for haven't you always known Dandelions ever since you were a tiny baby? How you love these golden heads! You would like to kiss them, every one, and you feel such joy in your heart, for now you know that spring is here, and spring is the happiest time of all, you think.

Once you found a Dandelion weeks before any one else had spied one anywhere, 
and how proud you were! It grew close to the ground, out from its rosette of ragged-looking leaves, and you would not pick it until you had shown it to Mother and Father, and every one in the house.

When do you love Dandelions better, when they first appear or when they turn to feathery balls of silver, and a puff sends the silver th r e a d s floating in the air? Attached to these
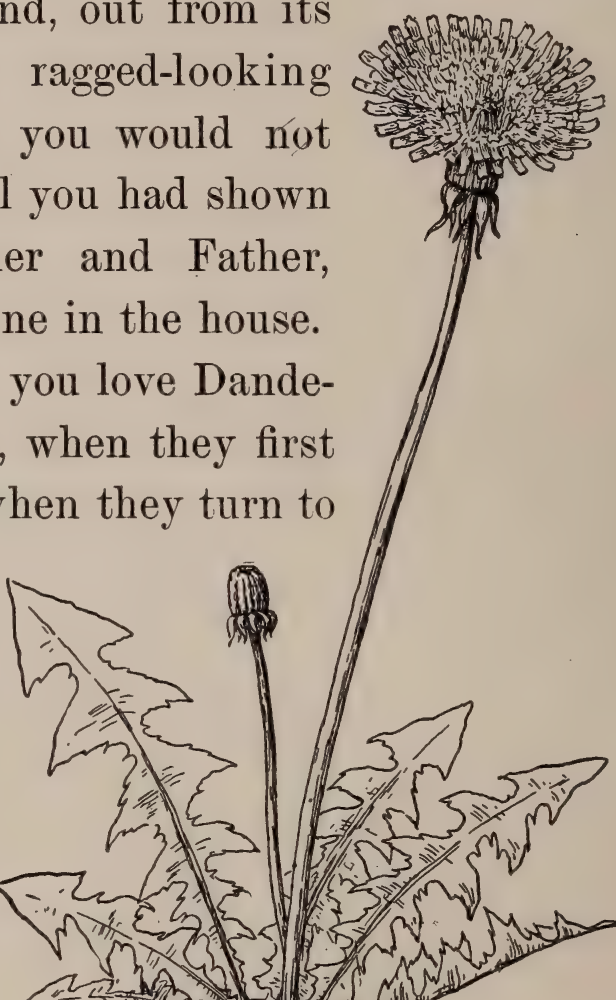
threads are tiny brown akenes containing seeds; so when you blow the Dandelion heads, you are sowing seeds for another year. Did you know that? The stems are bitter and have a milky juice, but you like to put them in your mouth and make curls of the long stems. What royal crowns can be made of these yellow blossoms! Truly crowns of gold, fit to grace the head of a queen.

Dandelions have many cousins, and relations far and near, for they belong to a branch of the great Composite Family. They bloom almost all the year round, but we love the early spring ones best, don't we? 


\section{TO THE DANDELION}

Dear common flower, that groweth beside the way,

Fringing the dusty road with harmless gold,

First pledge of blithesome May,

Which children pluck, and, full of pride, uphold,

High-hearted buccaneers, o'erjoyed that they

An Eldorado in the grass have found, Which not the rich earth's ample round May match in wealth, thou art more dear to me

Than all the prouder summer blooms may be. 
Gold such as thine ne'er drew the Spanish prow

Through the primeval hush of Indian seas,

Nor wrinkled the lean brow

Of age, to rob the lover's heart of ease;

'Tis the spring's largess, which she scatters now

To rich and poor alike, with lavish hand, Though most hearts never understand To take it at God's value, but pass by The offered wealth with unrewarded eye.

- James Russell Lowell. 


\section{TRAILING ARBUTUS}

Heath Family

Epigoea repens

\section{MARCH - MAY}

Grows close to the ground in sandy or rocky woods, often under pine trees. Long shoots spread or trail over the ground. The stems are reddish, rough, and hairy. Leaves are somewhat heart-shaped, evergreen, with veins forming a network. Flowers regular, pink, or sometimes white, fragrant. The corolla is five-lobed, salver-shaped, the calyx of five sepals, thin and scale-like. There are ten stamens with twocelled anthers opening lengthwise; one pistil with a five-lobed stigma. The seeds are small. 


\section{TRAILING ARBUTUS}

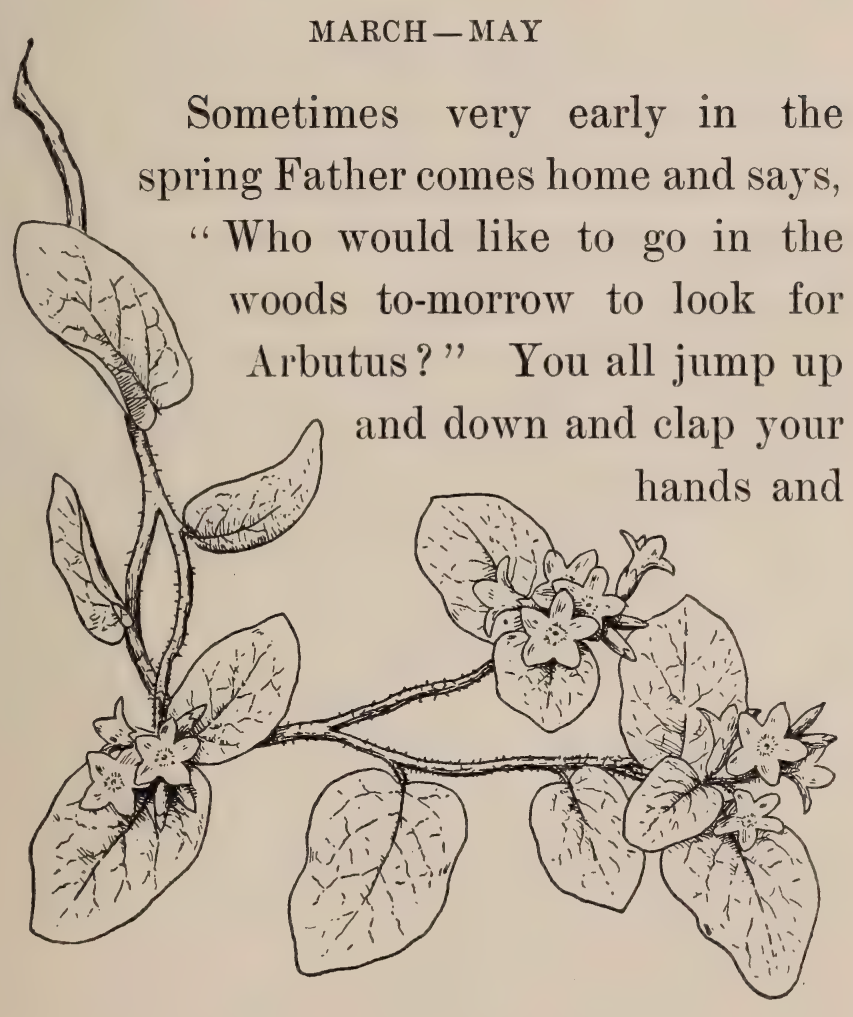


can hardly wait for morning to come; and you wonder if it will rain, or if the sun will be good enough to shine, and you are all impatience. You get into your little bed and shut your eyes, - oh, so tightly! - and then open them every minute or two to see if morning has come. All at once you find it really is morning; and then, after breakfast, what a joy it is to start out in the delicious air!

$\mathrm{Oh}$, the dear woods, all fresh and fragrant with the smell of pine needles and the damp, sweet earth! How you wander about, poking with a little stick under last year's leaves, which make such a warm little bed for Arbutus! Sometimes you discover whole masses of the darling little flowers, sweet with the very breath of spring; and you stop and just 
love the baby flowers before you bury your little nose in their fragrance.

Father has told you many times to leave Arbutus where it grows, making the woods a treasure-house, and not tear it away from its home, as many careless and thoughtless people do. You know if you take all the flowers this year there may never be as many again, and then how every one would miss them!

You love to look carefully at one of the tiny flowers, to see how it is put together. The five little petals look like wax, sometimes such a delicate, beautiful pink, when the flowers grow where the sun can reach them; and sometimes almost white, when the leaves have covered the baby flowers too closely. The stems have a little furry look, and seem to be covered with tiny reddish hairs. The leaves stay 
on the little plants all winter, so they are called "evergreens." Father tells you that Arbutus belongs to a big family, called the Heath Family; and you are so glad to know that flowers have families, and you wonder what their cousins are like. Perhaps you will find some of the cousins some day, and you will look to see if they are at all like Arbutus. 


\section{MAYFLOWER}

What singing of the storm, 0 forest flower, What stir of rhythmic pines,

From drooping boughs what dripping of the shower,

\section{Fashioned your lovely lines?}

What melody of tides along the shore,

Sobbing from shelf to shelf,

What song the brooding mother-bird sings

$$
\text { o'er }
$$

In silence to herself?

What flush of timid sunrise, filtered through

The dusk with roseate glint,

What moonbeams in the mould and dark

$$
\text { and dew }
$$

Painted your perfect tint?

- Harriet Prescott Spofford. 


\section{BLUETS}

Madder FAMily

Houstonia cœrulea

\section{APRIL - JULY}

Found on moist banks or grassy places. The stems are from three to five inches high, smooth and slender. The leaves are very small, opposite. Flowers pale blue or white, with yellow "eye." The calyx is four-lobed. The corolla is funnel- or salver-shaped, four-lobed, with the tube longer than the lobes. There are four stamens, and one pistil with one style and two stigmas. These are not the same in all flowers; some have long stamens and short pistil, while others have short stamens and a long pistil. Seeds are in a two-celled pod, and are saucershaped or thimble-shaped. 


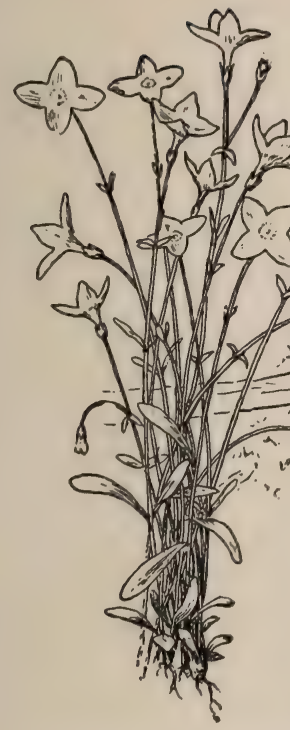

\section{BLUETS : INNOCENTS}

APRIL - JULY

meadow sprinkled all over with the dear little Bluets! They are like fairy flowers, and you love their pretty blue faces with the tiny yellow centre. How many of them there are, scattered all over the fields like a carpet for Titania to dance upon! Sometimes they are almost white, 
and then the fields look as though the snow fairies had been at work. You watch the butterflies flitting about from one tiny blossom to another, and you almost expect to see the queen of the fairies herself floating along on gossamer wings.

These little blossoms are so dainty, each with its four tiny petals, and the funnel-shaped tube, in which is concealed one drop of honey, eagerly sought by butterflies. Although the flowers are so small, they have many names; but the one "Innocents" seems to fit them best. These fairy plants have several cousins, some big ones, too, like Button-bush and Cape Jessamine, as well as the tiny partridge berry, loved by the birds. All these plants belong to the Madder Family. 


\section{BLUETS : INNOCENTS}

Have you seen the tiny babies, The little Bluets frail;

All nestling close together, Their faces small and pale?

But they're brave and uncomplaining

'Neath stormy April skies,

As they lisp, "The spring is coming!"

With joy in their bright eyes.

"Innocents," the children call them -

These floral babies small,

Of Mother Nature olden,

Whose broad lap holds them all;

To her arms she calls her darlings

And whispers to them, "Dears,

To mortals sad and weary

You bring back childhood's years."

- Ray Laurance. 


\section{COLUMBINE}

Crowfoot Family

Aquilegia Canadensis

\section{APRIL - JULY}

Found in rocky places. The stems are branching. The leaves much divided, with lobed leaflets. The flowers are large, nodding, bright red with yellow inside. Calyx of five bright red sepals, the corolla in the form of long hollow spurs that hang down between the sepals. The stamens are long and projecting, and there are five pistils with slender styles. The seeds are in long, narrow pods, many seeds in each pod. 


\section{COLUMBINE}

\section{APRIL - JULY}

Nodding down at one from the top of high rocks, or peeping out from little crevices where we might think it impossible for

a flower to grow, are our dear spring friends, the Columbines. Don't you love their nodding heads, tossing with every little breeze and seeming to smile at you with all the freshness and joyousness

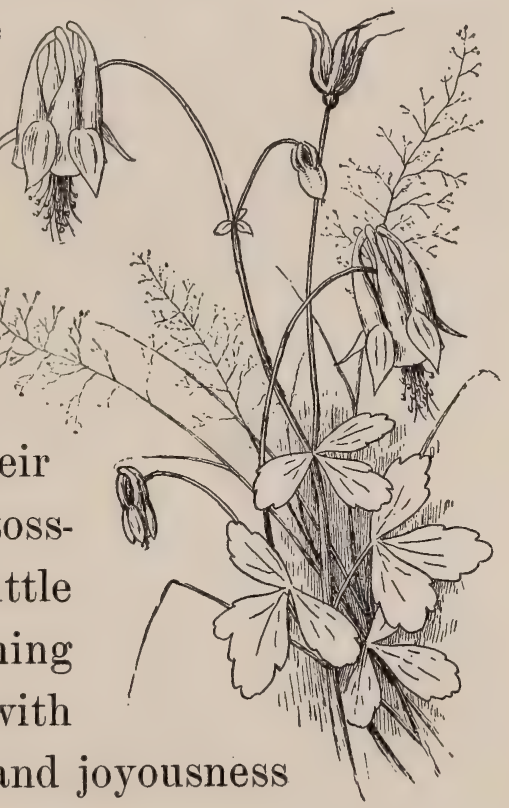


of spring? It is worth the climb to get beside them in their rocky nest, and one feels the whole friendliness of Mother Nature when looking at these gay little flowers. Bright with their red and yellow, they look so happy that we have no desire to tear them from their home, where they dance in the breeze and almost seem ready to fly away for very joy. Mother tells you to leave these little friendly sprites to their happiness, and you' regretfully clamber down, with many backward glances, wishing that some of the dear flowers grew right in your own little garden, where you could watch them every day. Then you are eager to hear about them, and question Mother closely as to their cousins. They belong to the same family as the Buttercups, though they do not look much 


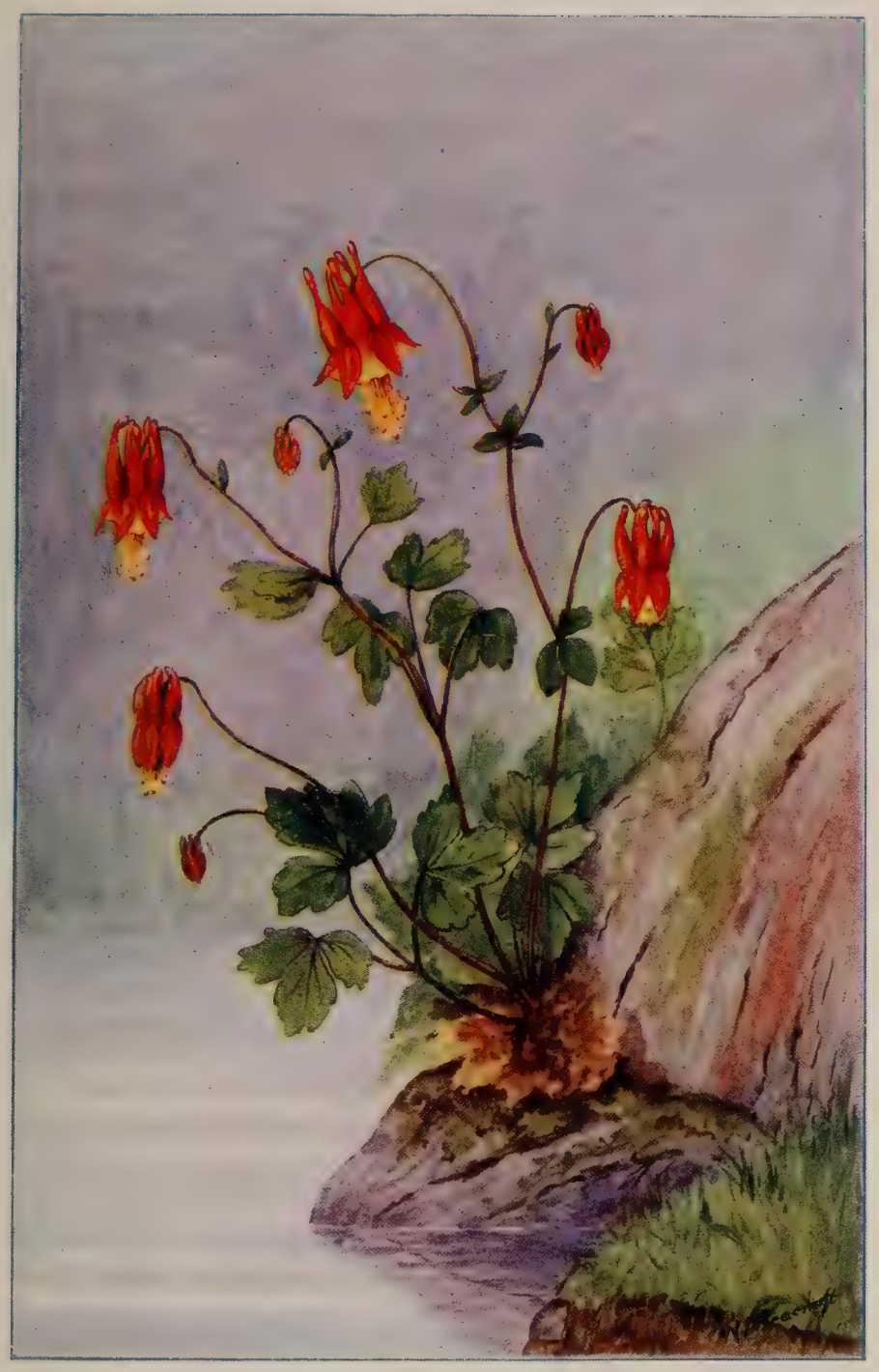

COLUMBINE 

alike, do they? The Crowfoot Family is quite large, and you will find more cousins some other day. The Columbines have another name, a long, hard one that means eagle. Do you see the long spurs at the top of each flower? It is said some one long ago thought these spurs looked like eagle's talons, so he gave the flowers the name Aquilegia. 


\section{THE COLUMBINE}

Gay in her red gown, trim and fine,

Dances the merry Columbine.

Never she thinks if her petals shall fall ;

Cold rains beating she does not dread;

Sunshine is round her and spring birds call,

Blue are the skies above her head.

So in her red gown, trim and fine, Merrily dances the Columbine.

- Arlo Bates. 


\section{A FLOWER ACQUAINTANCE}

I met a little lady,

A stranger here, mayhap;

She wore a gown of green,

She wore a scarlet cap.

Graceful was her figure,

Her manners very fine;

A fairy airy creature,

Her name was Columbine.

Her pasture was her parlor,

Very sweet the views;

The wind from every corner

Brought the latest news.

- Mary F. Butts. 


\section{DUTCHMAN'S BREECHES}

Poppy Family

Fumitory Family (Gray)
Bicuculla Cucullaria

Dicentra Cucullaria (Gray)

\section{APRIL - MAY}

Found in woods. Delicate, smooth plants, five to ten inches high, rising from a bulbous base. Leaves all from the base, pale beneath, slender petioled, compound in threes, divisions with stalks, and finely cut into many long and narrow, or oblanceolate, parts. Flowers in racemes, nodding, white or very pale pink with yellow tips, spurs widely spreading. Calyx of two sepals, scale-like. Corolla heart-shaped at base, petals four in two pairs, close together, outside pair oblong, concave with spurs at base, spreading at top; the inner pair narrow, winged on the back. There are six stamens in two sets, and a pistil with slender style and two-lobed stigma. The seeds are crested. 


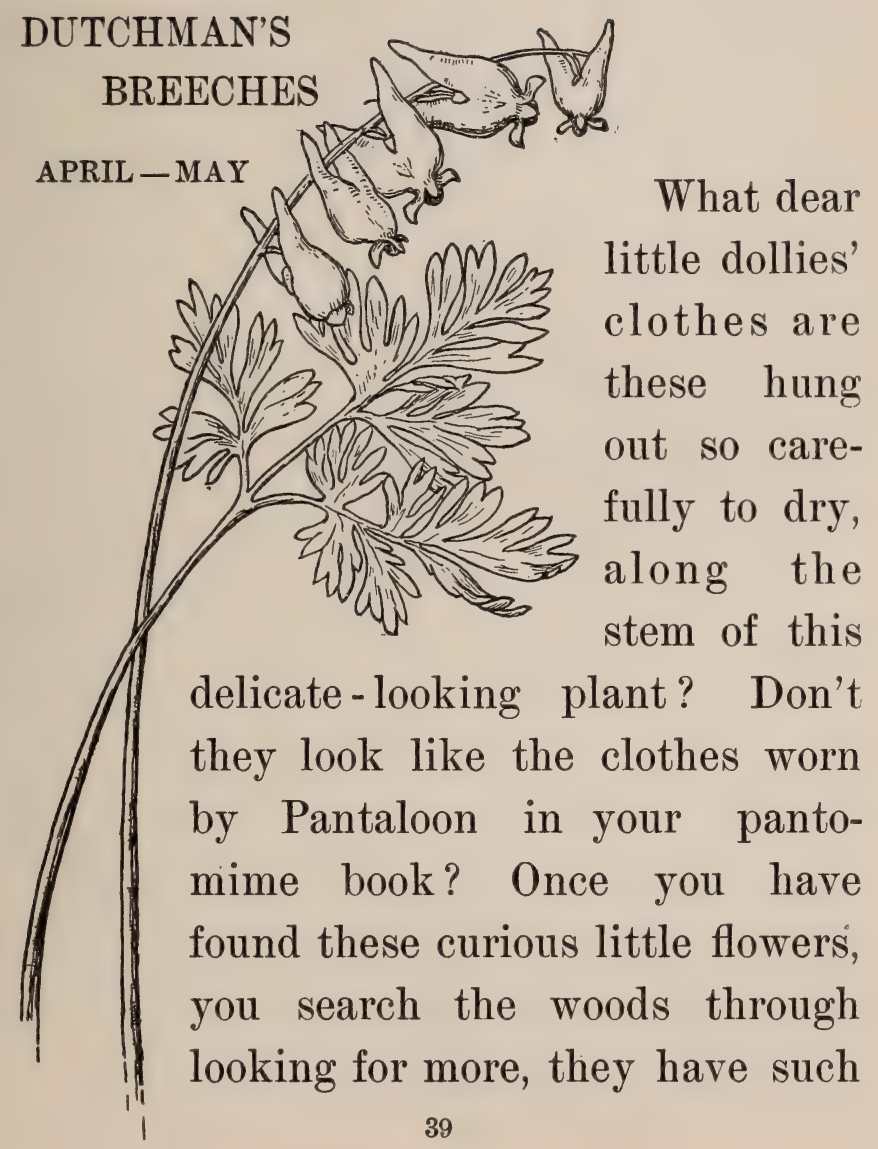


a fascination for you. You remember that in Grandmother's garden there are some flowers somewhat like these, only they are bright red, almost the color of blood, and their name is Bleeding Heart.

You like the dear little flowers in the woods better though, and pretend that you have just washed all these clothes for your Dutch dolly Nikolas, and hung them up to dry. You know that this arrangement of flowers is called a "raceme," and you will find many other flower friends growing in the same way, though none of them quite like these in their quaint daintiness.

Once, near the top of a mountain, you found a cousin of Dutchman's Breeches. You were sure, for the leaves were much the same, and the flowers looked a little as though they might be the other flowers 
cut in half. They were pink, tipped with a pale yellow, while the Dutchman's Breeches are white, also with a touch of yellow. The flower cousin's name was Pale Corydalis, and you thought it very beautiful, and you liked to play with the long pods, which contained many seeds. 


\section{BIRD-FOOT VIOLET}

Violet Family

Viola pedata

\section{APRIL - JUNE}

These grow in sandy or light soil, from short and thick or tuber-like rootstock. The leaves are alternate, cut into narrow divisions so that they have a resemblance to birds' claws. Flowers quite large, violet-blue or sometimes darker. Calyx has five sepals, which remain after the seeds have ripened. The corolla is of five petals, unequal in size, the lower one with a sac or spur at the base. There are also inconspicuous flowers among the leaves, called cleistogamous flowers, in which seeds ripen. There are five stamens, short, with very broad, flat filaments; anthers on inner side, enclosing the one pistil. Pod one-celled, containing several rather large seeds. 


\section{BIRD-FOOT VIOLET}

\section{APRIL - JUNE}

\section{The violet-covered}

hills! One morning in spring you gain the top of the first little hill and look across, where, as far as your eye can see, the ground is carpeted with the pale blue Bird-foot Violet. Best loved of all
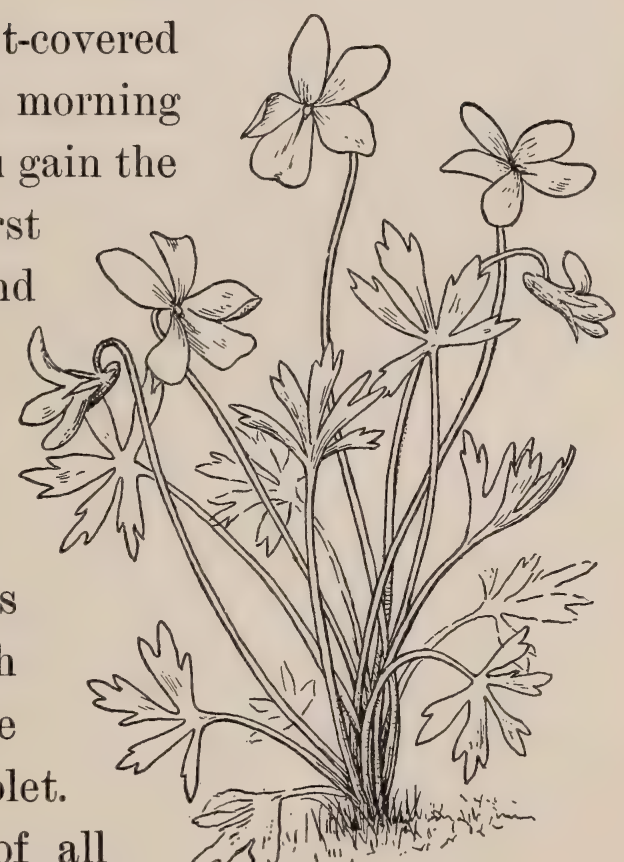
the family, how anxiously you have awaited their coming! Day after day you have walked over to the little hills, and sometimes discovered one or two small clumps of these darling flowers; but now the hill is fairly blue, and your joy knows no bounds. Their fragrance is of the breeze that sweeps gently over their heads. Indeed, the soft air, the songs of the birds, and the smell of the moist earth of springtime are all forever associated with the perfume of these dear flowers. You are displeased with people who can find no fragrance in them. To you they are sweeter far than even the tiny White Violets that you often find in the swamp close by. The Bird-foot Violet breathes of spring and joy, besides being a delight to the eye.

You wonder why its leaves are so dif- 
ferent from the other Violets that you know, and are pleased to find a resemblance to a bird's foot or claw. One day you found a pink Violet, and how delighted you were! How you searched for another like it, but to this day you have not found one pink one, though you have found many different shades of violet and blue, some very pale and others deep, deep blue like the sea. You love their bright faces, with the yellow centres and the dark veinings on the lower petals.

I'hese charming friends are usually found growing on high, sandy places, like the hills where you first became acquainted with them. 


\section{WINTER CRESS}

\section{MUSTARD FAMILY Barbarea stricta \\ Barbarea vulgaris (Gray) \\ APRIL - JUNE}

Is old gardens, fields, and waste places. Branching herbs, with angled stems. Leaves pinnatifid, or divided, alternate. Flowers bright yellow, in racemes. Calyx of four sepals, which fall off before the fruit ripens. Corolla of four petals in form of cross, nearly equal, generally clawed. Stamens six, two shorter than the other four. Pistil with a short style and stiyina two-lobed, or nearly rounded like the head of a pin. Pod, or silique, long and narrow, four angled. One row of seeds in each cell, flat and oblong. 


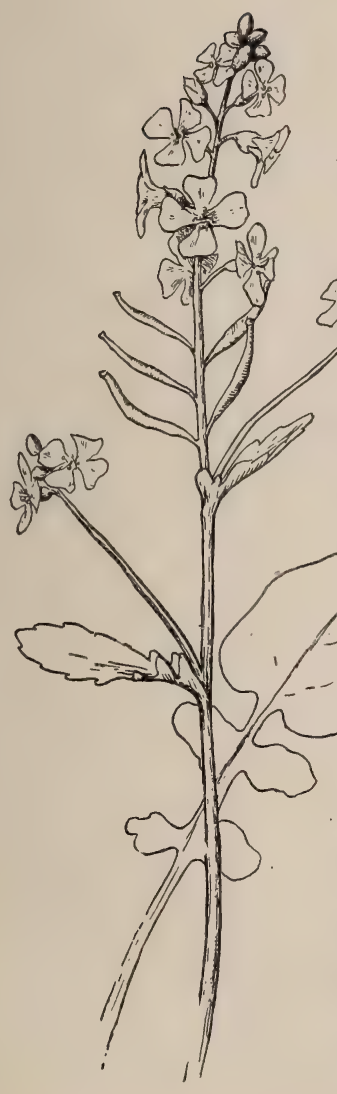

\section{WINTER CRESS}

APRIL - JUNE

Very often you see Winter

Cress in fields and

along the road, and you like its bright yellow flowers. Sometimes it is called Yellow Rocket, - you know that flowers often have several names. You notice that the leaves are of different shapes - some more cut and notched than others. This yellow flower has numbers of relatives, for 
it is a member of the Mustard Family. You know what mustard is like, don't you, because once you took some in your mouth by mistake, thinking it might be custard, and how it burned your tongue! All the members of this family have a sharp, biting juice, though it is more stinging in some than in others. Water Cress, too, belongs to the Mustard Family. You are very fond of looking for that in the little clear brook at the edge of the meadow, aren't you?

It is quite easy to know the flowers that belong to this family, for they are much alike, varying in size and color, but nearly all with four petals spread out in the shape of a cross. It is interesting to see that the seed pods are almost always on the plant before all the flowers disappear. You are surprised, aren't you, 
to find that so many plants have long pods, like peas and beans? The seed pods of mustard are of many different shapes and sizes. In old-fashioned gardens is one of the mustards with round, flat pods which become very satiny and like silver, so that they are extremely pretty. This plant is called Honesty, or Satin-flower. 


\section{JACK-IN-THE-PULPIT}

Arum Family

Ariscma triphyllum

\section{APRIL - JUNE}

Found in rich woods. The stem rises from a corm shaped like a turnip. The leaves are divided into three leaflets, with lower end of the stalk sheathing the stem, which ends in a long spadix. The spadix is a kind of fleshy spike with flowers only at the base, where it is enveloped by the lower part of the greenish, purplish spathe. Flowers are small and inconspicuous. The spathe is sometimes green and white, sometimes purple and green, and arches at the top like the sounding-board of an old-fashioned pulpit. Fruit, bright scarlet berries, closely packed on the spadix. 


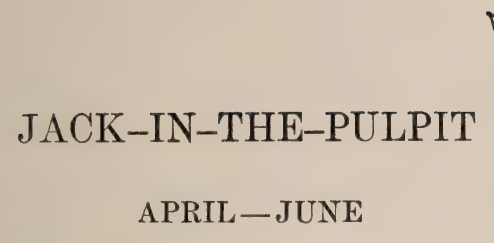

Dear little preacher of the cool, rich woods, what is the text of his sermon? He is one of your best loved friends, and how many times you have wished that the fairies would give you the power to listen to this tiny preacher. You have no doubt of his really speaking in some unknown tongue, for doesn't he stand up day after day straight and tall in his little pulpit, and are not the plants all about

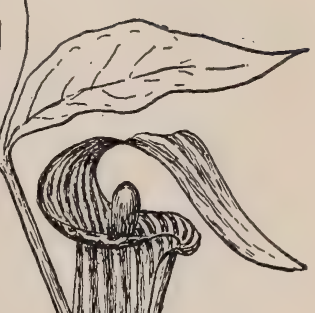
(1) 
behaving well and listening intently? To be sure there are sometimes some very naughty-looking Toadstools near by, and the queer white Indian Pipe, but are they not all hanging their heads in shame?

Sometimes Jack has a gay little pulpit striped with purple and green, sometimes it is green and white or green only, with the two leaves floating above like banners. Each leaf is divided into three leaflets, and Jack's banners are raised high in the air to proclaim that he is on duty in his little pulpit. We know that Jack is a friendly little preacher and has nothing but good to say of his neighbors, and his sermons must be full of the beauty and joy of spring.

Jack-in-the-Pulpit has several cousins that are familiar to you. One of these is 


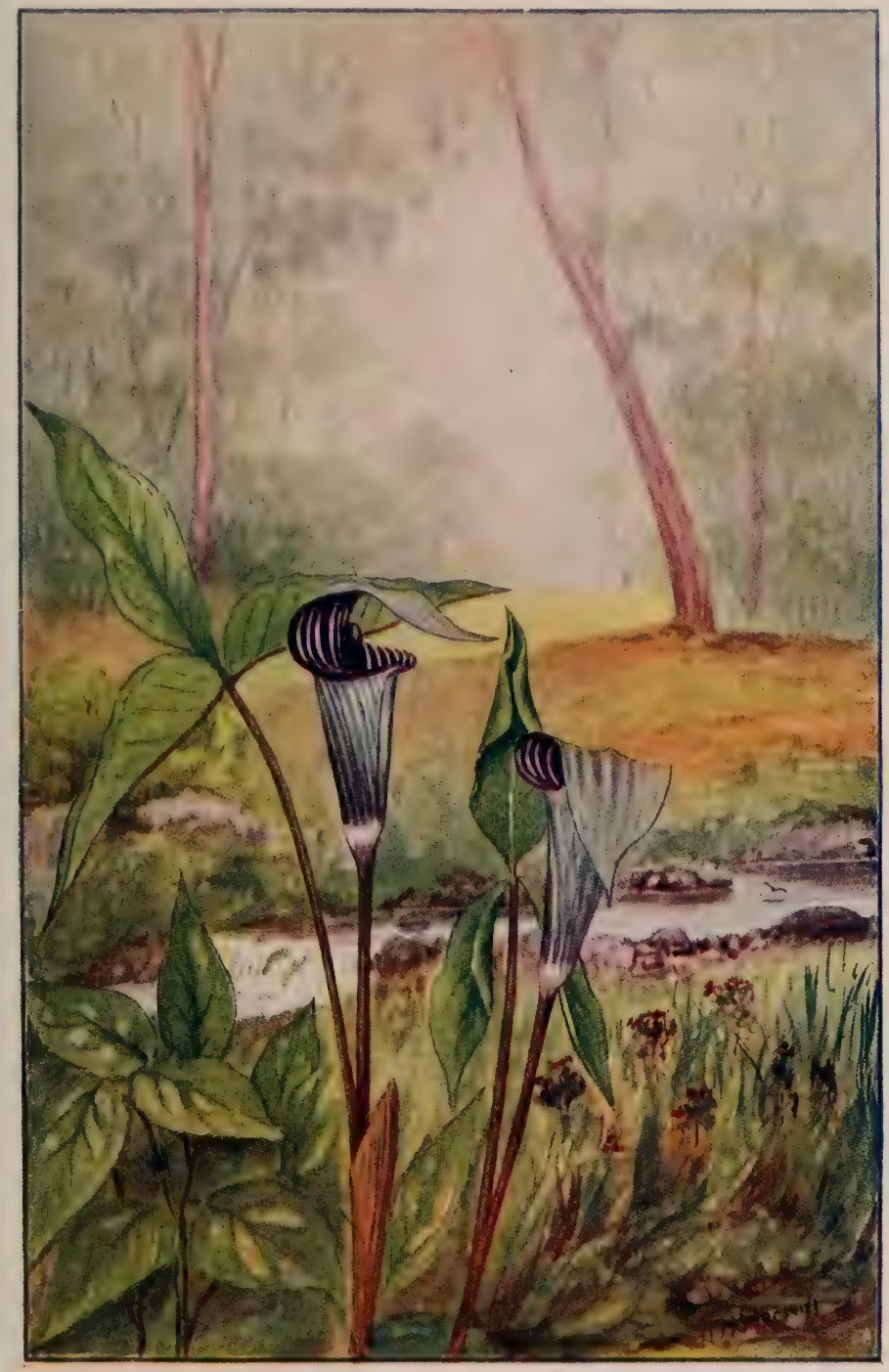

JACK-IN-THE-PULPIT 

the Calla Lily, which you see very often in gardens. Sweet Flag and the common Skunk Cabbage are also members of the Arum Family. 


\section{JACK-IN-THE-PULPIT}

Jack-in-the-Pulpit preaches to-day

Under the green trees just over the way.

Squirrel and song-sparrow, high on their perch,

Hear the sweet lily-bells ringing to church.

Come, hear' what his Reverence rises to say,

In his painted pulpit, this calm Sabbath day.

Fair is the canopy over him seen,

Pencilled by nature's hand, black, brown, and green.

Green is his surplice, green are his bands; In his queer little pulpit the little priest stands. 


$$
\text { JACK-IN-THE-PULPIT }
$$

In black and gold velvet, so gorgeous to see,

Comes with his bass voice the chorister bee.

Green fingers playing unseen on wind lyres -

Low-singing bird voices - these are his choirs.

The violets are deacons, I know, by the sign

That the cups which they carry are purple with wine.

— Edited by J. G. Whitтier. 


\section{BARBERRY}

\section{Barberry Family Berberis vulgaris}

\section{$\mathrm{MAY}$ - JUNE}

These shrubs run wild in thickets and along roadsides. The wood and inner bark is yellow. The leaves have sharp, spiny teeth, and are clustered in the axils of spines which answer to leaves of the shoots of previous year. The flowers are in long, drooping racemes, and are yellow. Corolla, of six petals. The calyx has six sepals, with bracts or outer sepals behind the true ones. There are six stamens, one before each petal, with anthers opening like trap-doors hinged at the top. There is one pistil. The fruit consists of long, red, sour berries which hang in drooping racemes. 


\section{BARBERRY}

MAY - JUNE

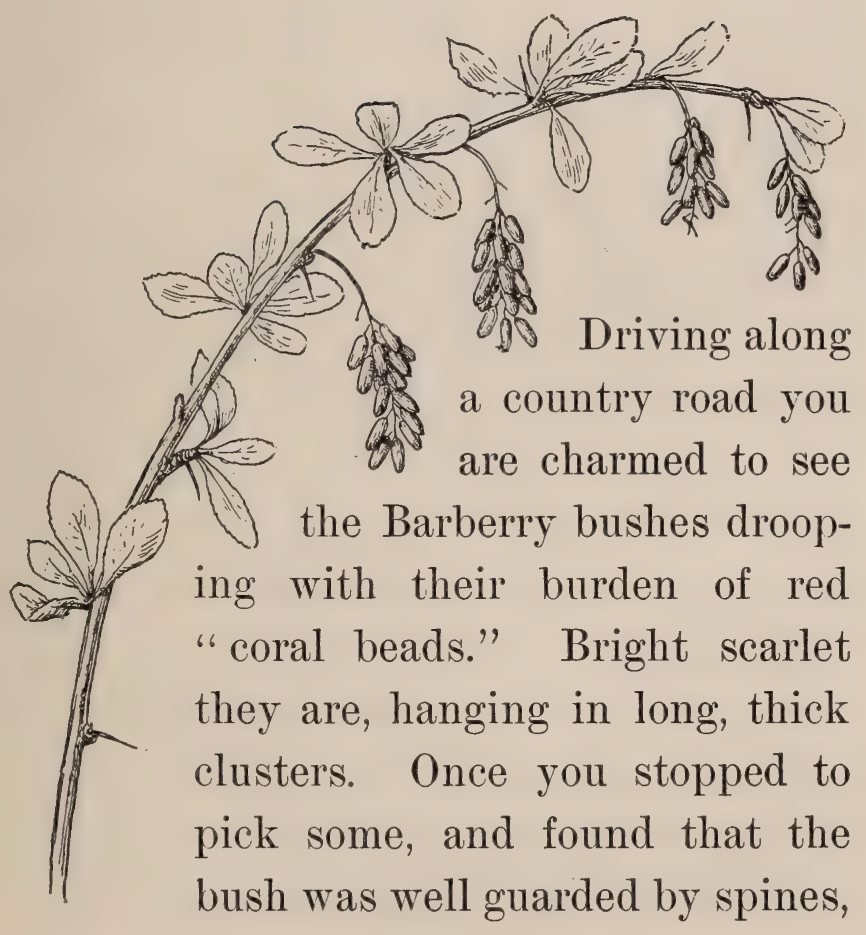


large and small, on leaves and stem, so that you had to be careful where you put your fingers.

You like the taste of the berries, though they are very acid and somewhat "puckery." Sometimes nurse gives you a delicious cool drink made from Barberries, and you think that when you grow up you will drink Barberry water always instead of milk.

You wonder why the yellow blossoms that were on the Barberry bushes in the spring should have changed to red berries. The change pleases you, for you like the berries better, though the yellow flowers are pretty, clustered in long "racemes." You remember that the flowers of Dutchman's Breeches grow this way, as also your garden favorite, Lily-of-the-Valley, and we shall find 
many other flower friends with the same arrangement.

You would like the Barberry flowers better if their odor was not so disagreeable, and if there were not so many bees and insects flying about the bushes in the spring. We think Barberry bushes are ornamental at any season of the year, and make an attractive hedge about fields and meadows. Perhaps the farmers would not agree with us in this, as they feel that the Barberry is injurious to some of their crops, particularly wheat. 


\title{
$\int$
}

\section{PITCHER PLANT}

\author{
Pitcher Plant Family
}

Sarracenia purpurea

$$
\text { MAY - JUNE }
$$

These interesting plants are found in bogs. The roots last from year to year. Leaves are from the root, in form of pitchers, winged down the inner side and open at the top; where there is a kind of arching hood. The scape is tall, bearing one large, nodding, purple flower. Calyx is of five sepals, colored, with three little bracts at base. Corolla of five petals, fiddle-shaped, curved over the large, flat, or somewhat rounded petal-like top of the style. There are many stamens. Pistil has a large yellow disk-like or umbrella-shaped style with five angles, and a small hooked stigma at each angle. Pod is rough-warty, with many seeds. 


\section{PITCHER PLANT}

\section{$\mathrm{MAY}-J U N E$}

A plant with truly little pitchers growing on it. What more delightful than this? You love to see the plant after a rain-storm, when the pitchers are half full of water,

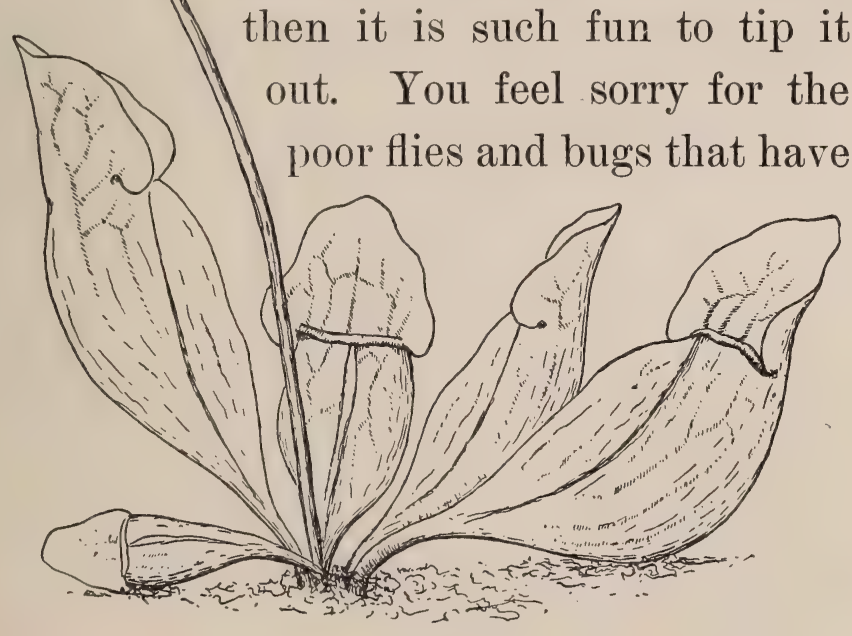


fallen in, and wish you had been there to rescue them. One day you were most surprised to find that the Pitcher plant had blossoms, as well as these wonderful little pitchers. What strange foreignlooking blossoms they were, too; not only on account of the color, which was most gorgeous, but they were also of a peculiar shape. Sometimes the calyx was purple and the corolla pink, turned in a curious way over a large "disk-like" yellow style. You revelled in the color of the blossoms, but liked the purpleveined pitchers better. At first you thought the flies had fallen in the water, but you learned that the pitchers were made to catch unwary insects, and were sticky inside and covered with little hairs that made it impossible for an insect to crawl out after he once fell into this 
trap. In this way food is furnished for the plant. You thought all plants drew their nourishment from the ground, didn't you? There are a few, like the Pitcher plant, which are provided with traps to catch insects, and they are called carnivorous plants. Venus's Fly-trap and Round-leaved Sundew are this kind of plant. Have you ever seen either of them? 


\section{WILD LUPINE}

Pulse or Pea family

Lupinus perennis

MAY - JUNE

IN sandy soil, and on high, gravelly banks. The stems are erect, hairy, and from one to one and a half feet high. The leaves are of from seven to eleven leaflets, all from the top of the leaf-stalk. Flowers purplish blue, in long, thick racemes, papilionaceous, which means butterflylike. The corolla is of five petals, the large upper one called the standard, the two side ones called wings, and the two lower ones the keel. The standard has rounded sides, rolled backward, the wings enclose the keel. The calyx is two lipped. Stamens, ten with five anthers differing from the other five. Pod, or legume, like that of a pea, several seeded, opening on both sides. 
WILD LUPINE

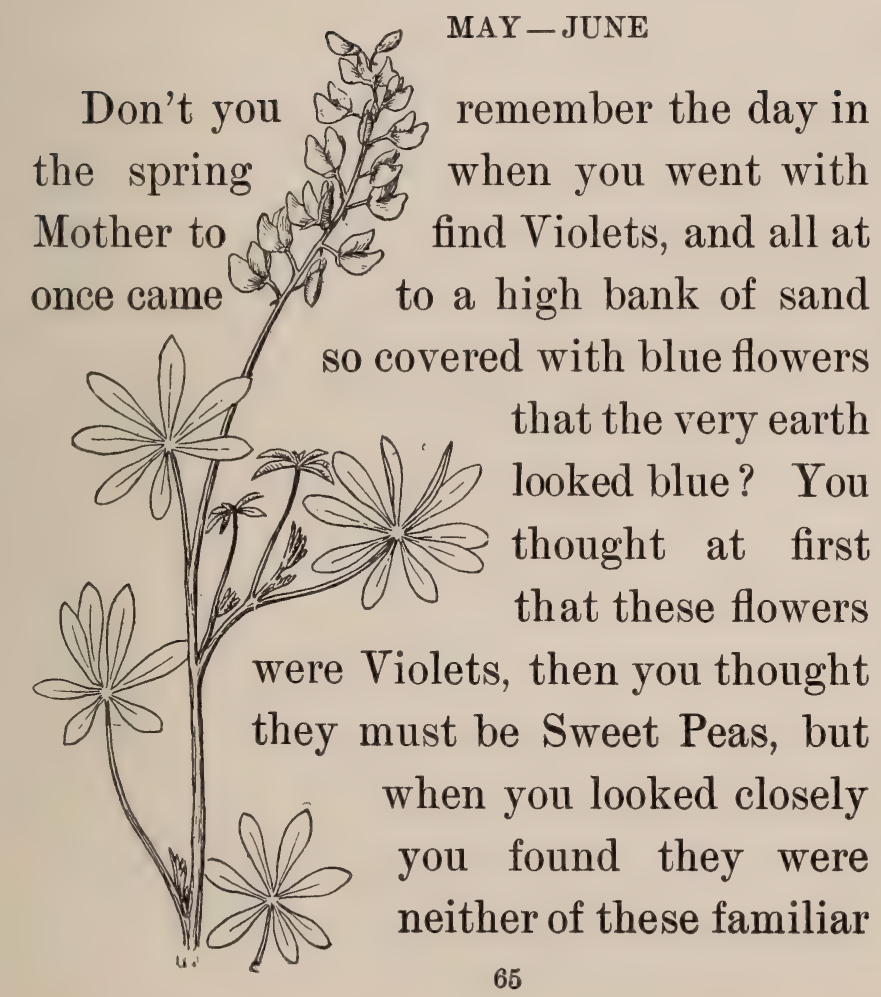


friends, and you asked Mother what the pretty blossoms were. She told you that their name was Lupine, and that they were related to Sweet Peas.

How delighted you were with the fanlike leaves, each with many leaflets. You counted and found that some had seven leaflets, others eight, and some even had eleven. You were more pleased with the blossoms; they were such a beautiful blue, and did look a little like Sweet Peas, but more like Wistaria, because they grew with many flowers along one stem.

You looked at one of the flowers to see how it was put together, because it seemed to have wings and looked a little like a butterfly. Just then a bee came buzzing by and alighted upon one of the flowers near you. He stepped on the wings, when the two lower petals opened, 
and you discovered that in there was the storehouse where the honey was kept. You watched the bee go from flower to flower, and were so much interested that you forgot all about going for Violets.

You asked Mother to tell you more about the Lupine, and she told you some interesting things. One was that the plant goes to sleep at night, and sometimes in the daytime, when the little leaflets fold like an umbrella. She told you, too, that several of the cousins of Wild Lupine have a funny way of shutting their leaves if anything touches them. One of these relatives is called "Sensitive Plant." Locust Trees, Acacia, Clover, Beans, Peanuts, and many other plants well known, also belong to the Pulse or Pea Family. 


\section{OXEYE OR WHITE DAISY}

Thistle Family

Composite Family (Gray)

Chrysanthemum Leucanthemum

MAY - NOVEMBER

Pastures, meadows, and waste places. Stem smooth, simple, or little branched, one to three feet high. Leaves at base coarsely toothed, narrowed into long, slender petioles; stem leaves mostly without petioles, partly clasping the stem, narrower, toothed; upper leaves very small and nearly entire. Flower heads one to two inches broad, on long, naked stalks. Ray flowers white, spreading, from twenty to thirty in each head, slightly toothed. Bracts of involucre oblonglanceolate, smooth, thin, dry margins. Disk flowers perfect, corollas with long and round, or two-winged tubes, and four to five cleft borders. Ray flowers with pistils. Akenes of disk flowers angled, or long and round, five to ten ribbed; those of ray flowers usually three angled. 


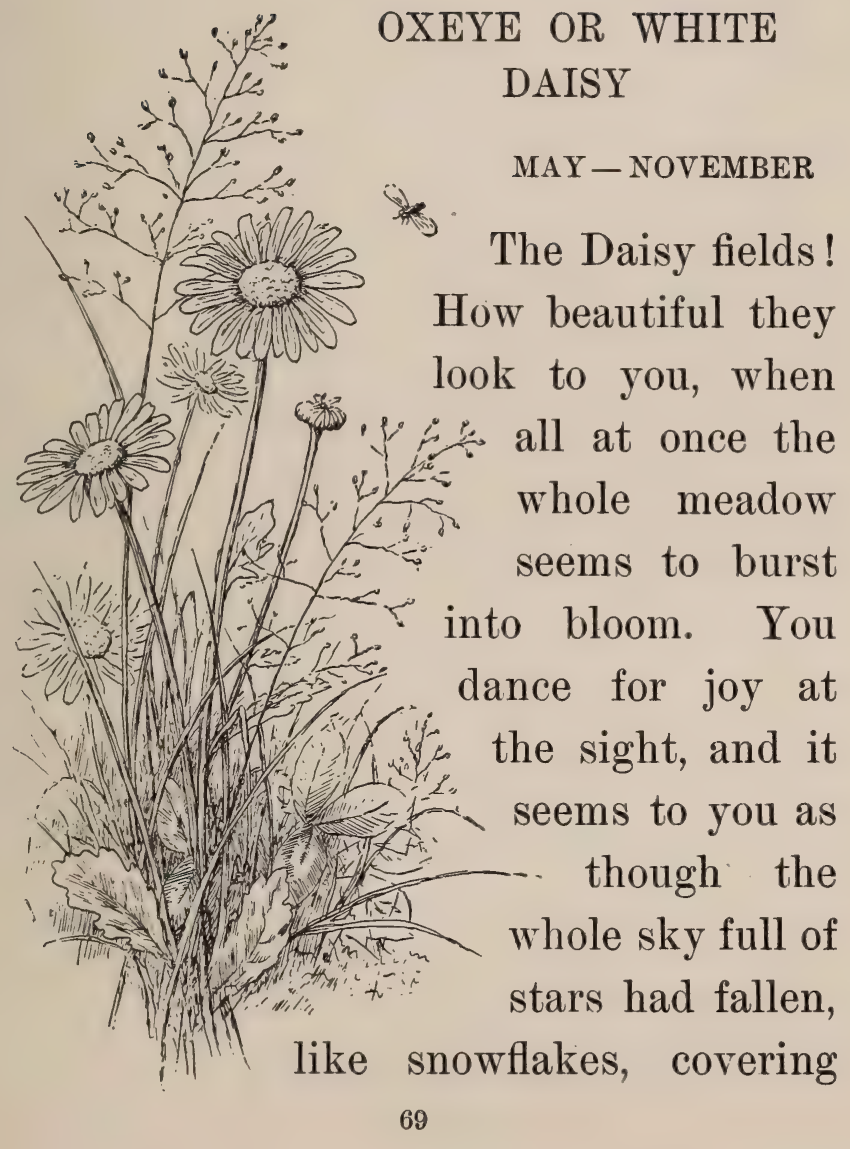


everything. You love the Daisies, and delight in gathering great bunches of them to fill the largest jars Mother will let you have.

How white the ray flowers are and how yellow the centres! Each white petal-like ray is a flower you know, and the yellow centre is made up of countless numbers of tiny flowers. Sometimes you pull the white flowers out one by one, counting the old game "Loves me, loves me not," then you take all the yellow flowers on the back of your hand and toss them into the air. You feel so sorry afterward to think that you have pulled this beautiful flower head all to pieces, but you see so many all around that you forget to be careful, and are reckless with happiness. Farmers find the Daisy very annoying, for it gets in the fields, and 
every year there are so many more that everything he plants would be crowded out if he did not keep constant watch. You don't see how anything so beautiful can be troublesome, do you?

You have noticed that when you carry Daisies home, no matter how wilted they look, if you put them in water they come up again bright and fresh, and almost seem to smile at you, thanking you for the refreshing drink. You will always love Daisies I am sure, for they are among your earliest friends. They belong to the Composite Family, and have such a long name that you will find it very hard to say - Chrysanthemum Lêcanthemum. Wouldn't you rather call them Daisies? 


\section{BOSSY AND THE DAISY}

Right up in Bossy's eyes, Looked the Daisy, boldly,

But, alas! to his surprise, Bossy ate him, coldly.

Listen! Daisies in the fields, Hide away from Bossy!

Daisies make the milk she yields, And her coat grow glossy!

So, each day, she tries to find Daisies nodding sweetly, And, although it's most unkind, Bites their heads off neatly!

- Margaret Deland. 


\section{DAISY GRANDMOTHERS}

We were sitting down in the grasses,

Deep in it, it was taller than we;

The daisies were there, close beside us,

In a circle they stood on a mound,

And auntie took out her sharp scissors

And she snipped them around and around,

Until each had a white cap border,

And she left them two petals for strings;

And then next she found a lead pencil

In her bag with the rest of her things;

And with that, on each yellow centre,

Auntie drew such a queer little face-

But look - you can see the grandmammas,

Here they are in the same grassy place!

-Anonymous. 


\section{MOUNTAIN IAAUREL}

Heath Family

Kalmia latifolia

MAY - JUNE

These shrubs are found in damp grounds and along mountains. The leaves are evergreen, shining, long, and pointed. The flowers are in large and showy clusters, and are pink and white. The corolla is slightly five-lobed, broadly open, with ten little depressions or hollows in which the anthers rest until disturbed by insects, when the elastic filaments fly up, releasing the anthers and sending out showers of fine pollen dust. The calyx is very small. There are ten stamens, with long slender filaments and short anthers opening by holes at the top. The one pistil has a long and slender style. The seed pod is globular. 


\title{
MOUNTAIN LAUREL
}

\author{
MAY -JUNE
}

Your happiness is quite complete when one day in May or June you see before you what seems like a whole garden of Laurel. You have climbed up

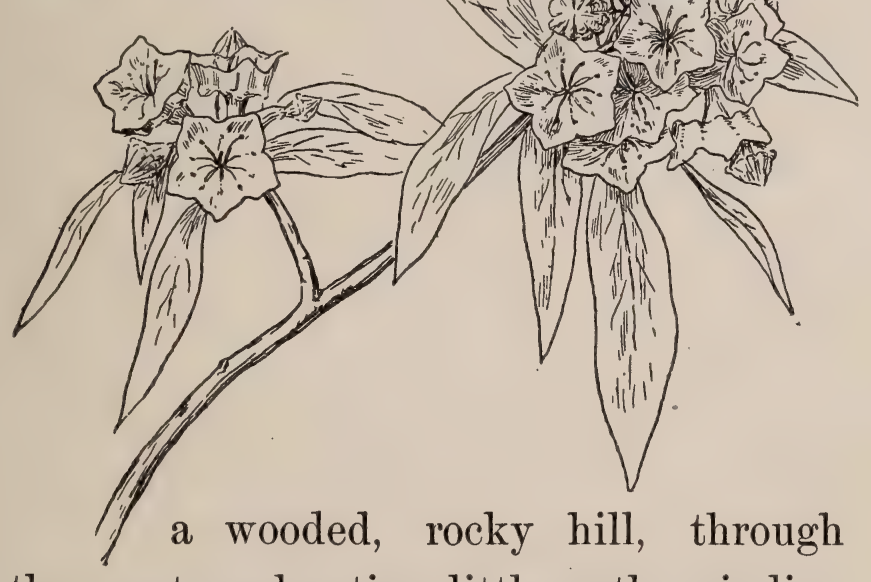

the most enchanting little path, winding 
up and up through fairy-land, it seems to you. You have stopped all along the way, for some new wonder or old friend among the flowers greets you at every step; but now you have reached the top. Oh, the wonder of the Laurel! You stop, and one by one the flowers you have gathered drop from your hand, for Laurel claims all your attention. Even the shrubs are attractive, with their many evergreen leaves; but when the Laurel is in full bloom, and the great clusters of white and pink flowers, shaded from the most delicate blush to a beautiful deep pink, greet your eye, both your eyes and heart revel in the glory.

Every blossom seems to you like a dainty china cup, exquisite enough for Titania to drink from. You are interested to see how each stamen fits into a little 


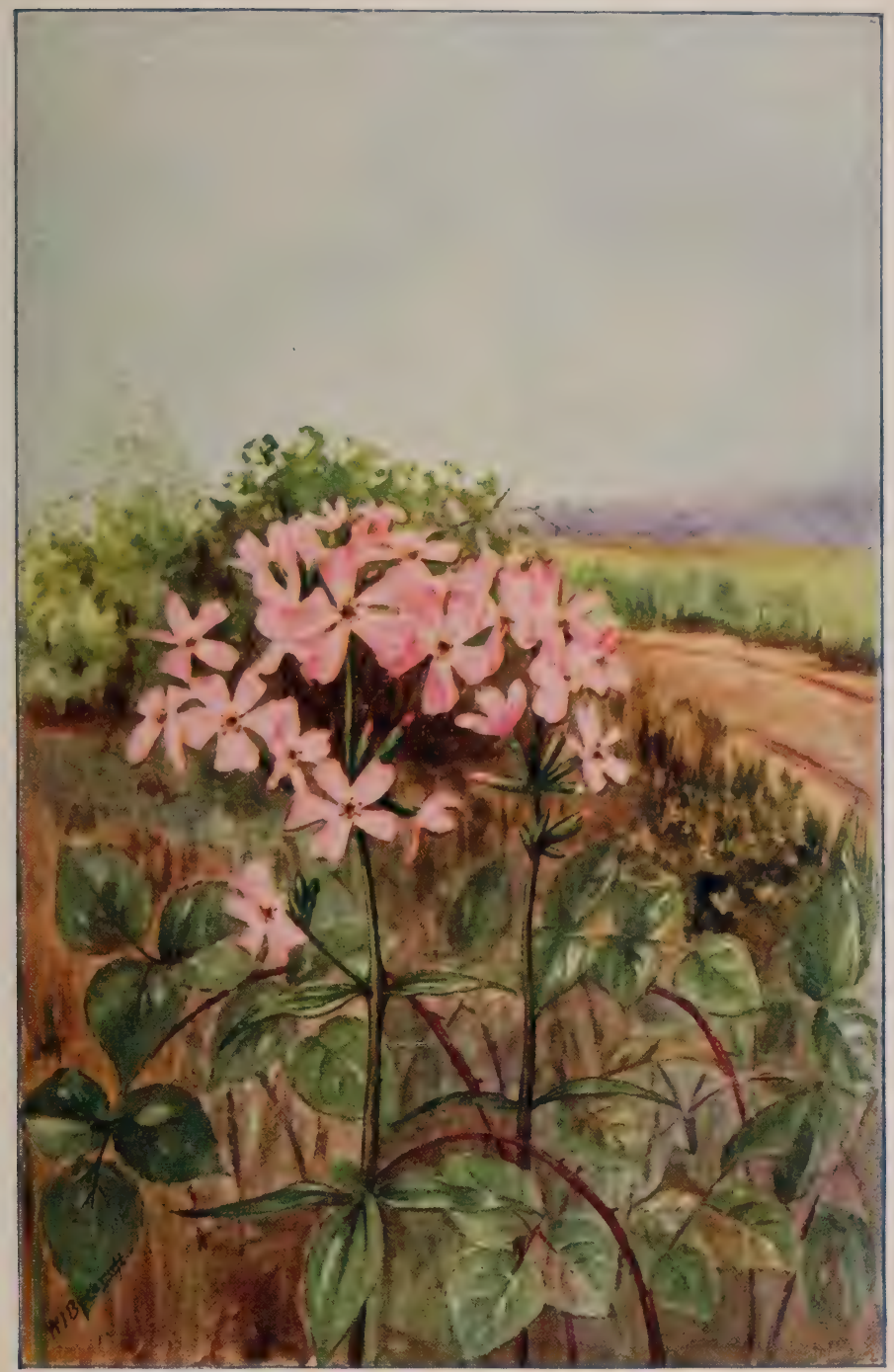

BOUNCING BET 

hollow in the corolla, and you notice that the gentlest touch makes one or more fly up, sending out a fine dust of pollen. You love the little buds, and are glad there are so many in the clusters. They remind you very much, the tiniest ones, of the little candies that were sprinkled over your last birthday cake. If only your birthday came in May or June you would gather a big bouquet of Laurel for the table every year; but, alas, it comes very late in the year when all your dear outdoor flower friends are taking their winter nap. It pleases you to know that Laurel is a cousin of Arbutus, for both flowers are so dear to you that you feel they ought to be related. Wintergreen also is a cousin, as that too belongs to the Heath Family. 


\section{MOUNTAIN LAUREL}

When, pale and pure against the sombre green

Of spreading hemlocks and close-crowding pines,

In northern woods thy moonlight beauty shines, -

Thou seem'st, 0 stately Kalmia, like a queen,

Alien and sad, exiled but not discrowned ;

A wanderer from distant tropic lands,

But regal still, and bearing in thy hands

Caskets of pearl and rose, securely bound.

Fair fugitive, I would not be too bold,

Nor seek to probe thy hidden history;

I pluck thy blossoms, not thy mystery; 


\section{MOUNTAIN LÁUREL}

Yet, I were rich indeed, with wealth untold,

If in some trusting hour thou wouldst unfold

The secrets that those cunning caskets hold.

- Emily Shaw Forman. 


\section{CELANDINE}

Poppy Family

Chelidonium majus

\section{MAY - AUGUST}

Found in waste lands and in gardens. The stem is branching, one to four feet high, with thick orange or yellow juice. Leaves divided or compound, lobed. Flowers yellow, growing in umbels. Corolla of four petals, which are crumpled in the flower bud. Calyx of two sepals, falling when the blossom opens. Stamens numerous. One pistil with a two-lobed stigma. Fruit, a long and narrow pod, containing many seeds. 


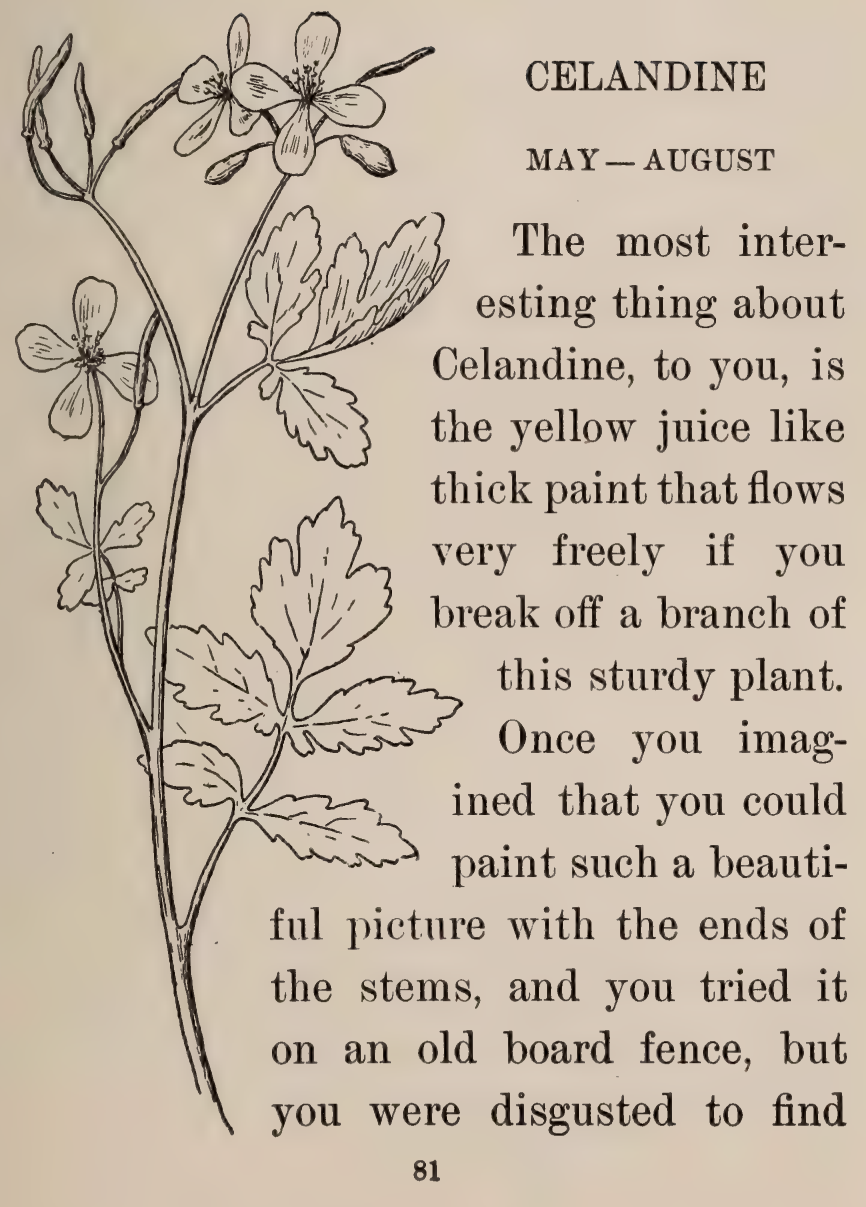


that the yellow color would not stay in spite of all your efforts. Privately, you rather despise the Celandine; it is one of the few flowers that really seems only a weed to you, and though the flowers are of rather a pretty yellow, they do not please you. The leaves are more interesting, you think. They look as though some elf had nibbled the edges all around just for mischief. Both leaves and stem are hairy. You are surprised to hear that Celandine is a cousin of the Poppies in your garden, and you look at the yellow flowers with more respect when you know of this relationship, for the Poppies are your joy and pride, and a cousin of theirs is worthy of some attention. "Poor Celandine," you think in your heart, "perhaps it couldn't help being unattractive; the Poppies may have taken all the good looks of the family." 
You wonder if Celandine would grow prettier if it had a nice little garden all by itself. It always seems to be crowded in with so many other weeds, Burdock, Plantain, and uninteresting plants, that you think it may need more room. Your own little garden is already full, and you just can't give up your Pansies or Poppies; so you take your little spade and trowel and clear a space around the Celandine in the vacant lot where you often find it growing. It is a difficult task, for it seems to be hopelessly tangled with all sorts of weeds and tiresome plants. You are proud of your Celandine garden and Mother knows just how you feel about it, but tells you that Celandine is one of the plants that will grow anywhere and anyhow, and does not object to being crowded. 


\section{LADY'S SLIPPER}

OrChis F AMiLY

Cypripedium acaule

MAY - JUNE

Found in the shade of evergreen trees, in moist or sandy ground. The rootstock is short and knotty, producing long, coarse, fibrous roots. The stem or scape is eight to twelve inches high, bearing one large flower. There are two leaves at the base of the scape, oblong, downy, and many nerved. Perianth is of two petals besides the lip, which is a large, inflated sac, purplish pink, split down the front but nearly closed; three sepals, spreading, greenish in color. There are two stamens fastened to the style, each stamen with two, two-celled anthers. The pistil has a broad stigma. Pollen is sticky on the surface, as if with a delicate coat of varnish. 


\section{LADY'S SLIPPER}

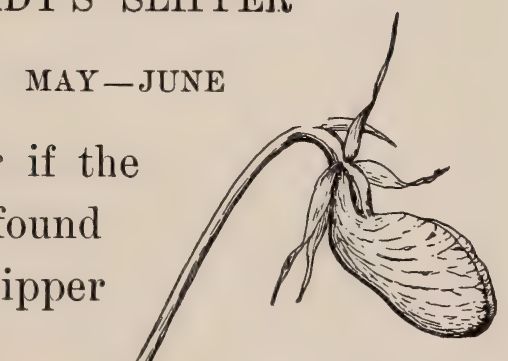

You wonder if the prince who found Cinderella's slipper
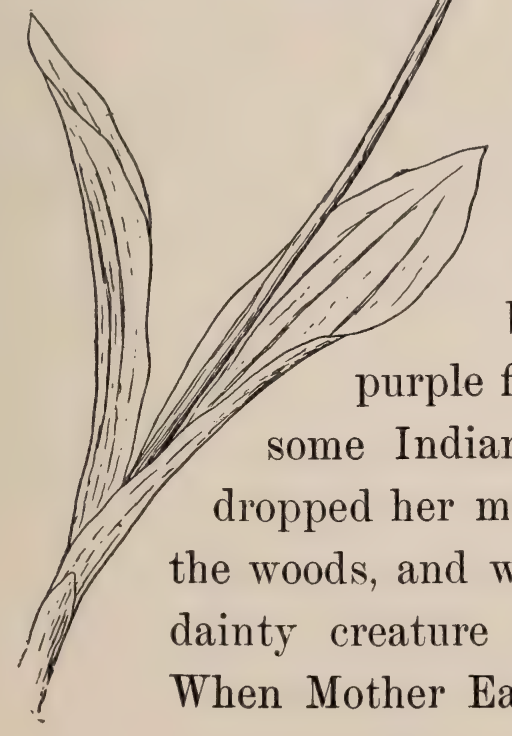
was half as happy as you, when you spy one of these beautiful pinkpurple flowers. Surely some Indian princess has dropped her moccasin here in the woods, and what a delicate, dainty creature she must be! When Mother Earth found this 
graceful shoe, you think she must have raised it high in the air to aid the princess in her search, - for of course she will return to claim it.

Suddenly you find a host of the exquisite blossoms in the pine woods, and then you know that they are fairy slippers. You have never thought of Indian fairies before, but what delightful possibilities it suggests. Perhaps you will find some tiny wigwams close at hand; here under this spreading pine tree is a charming spot for a camp fire.

Well, even if you are told that the Lady's Slipper is a member of the Orchis Family, the flowers of which take many fantastic shapes, you are sure in your heart that the Indian fairies have been busily at work making moccasins for all the tribe. 
What a beautiful color this flower is, veined so delicately with a deeper shade of purple! Isn't it always a joy to find one, and don't you every spring go eagerly to the spot where once you found so many? Unfortunately, these lovely blossoms are so coveted that they are getting very rare in some of the places where once they bloomed in profusion.

\section{LADY'S SLIPPER: MOCCASIN FLOWER}

Graceful and tall the slender drooping stem,

With two broad leaves below,

Shapely the flower so lightly poised between, And warm its rosy glow. 


\section{BLUE FLAG}

IRIS FAMILY

Iris versicolor

\section{$\mathrm{MAY}-J U L Y$}

In swamps and damp places. Grows from a creeping rootstock. The stem is stout, from one to three feet high, angled on one side. The leaves are sword-shaped, sheathing the stem at base. Flowers are large, showy, violet-blue variegated with white, yellow, and purple, from a spathe of two or more leaves or bracts. The perianth is of six divisions, the three large outer ones curving outward, the smaller ones inside erect or curving inward. There are three stamens with anthers facing outward, under the petallike lobes of the style. Pistil, one with the three divisions of the style like petals. Pod, three-angled and oblong. 


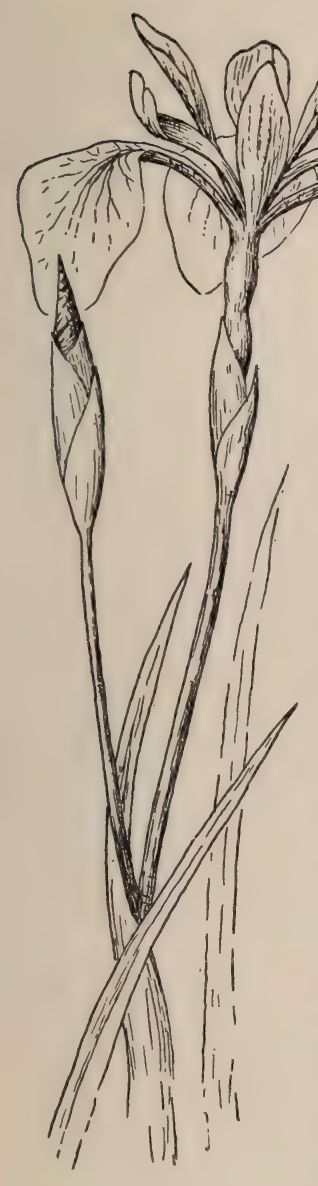

\section{BLUE FLAG \\ $M A Y-J U L Y$}

Somehow it always

seems to you as though the most beautiful Iris, or Blue Flag, grows just out of reach, yet how perfect is each flower in your hand! Truly, this seems like a royal flower, rich with its purple and yellow. "King of the Marshes" we might call it, as it stands up proudly and with a regal air close by the water's edge, and sometimes even in the little pools with 
which the marsh is dotted. In trying to gather some of these splendid flowers to carry home to Mother, you often get your feet very wet, as the ground all about is most uncertain and has a tricky way of suddenly disappearing beneath one's feet, leaving a black little pool or very wet spot in its place.

You love the little sharp-pointed buds, encased in a sheath of green; and the leaves are interesting too, looking like huge, huge blades of grass. But the flowers are your joy! A handful of these treasures makes the discomfort of wet feet a trifle not to be thought of. It seems to you as though a rainbow had given all its colors to these gorgeous flowers, and you are delighted when Mother tells you that Iris means rainbow. Next time after a shower, when the rainbow is in the sky, 


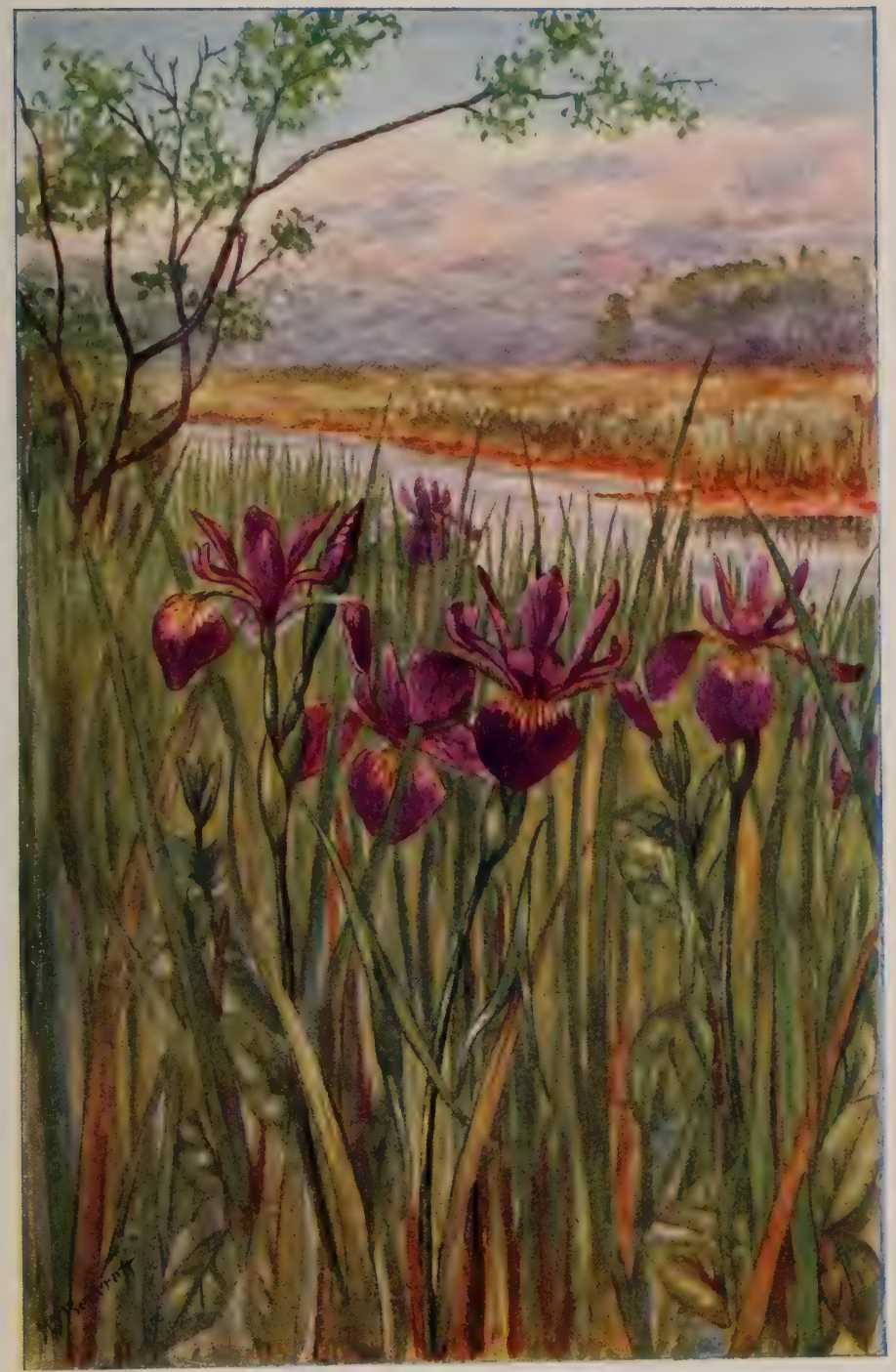

BLUE FLAG 

you mean to run down to the marsh and see if any more Blue Flag has blossomed. You are sure that the colors will be much brighter than any that you have ever found before.

See how the flower parts are divided into threes; the perianth, or outer part of the flower, has three large divisions and three smaller ones, then there are three stamens, and a pistil divided at the top into three petal-like parts. There are several flower families besides Iris that have the parts divided into threes, then there are flowers that are in fours, and many in fives. Isn't this interesting? Now you will look more closely at all the flowers you find to see how they are divided, won't you? 


\section{THE FLOWER-DE-LUCE}

Beautiful lily, dwelling by still rivers

Or solitary mere,

Or where the sluggish meadow brook delivers

Its waters to the weir!

Thou laughest at the mill, the whir and worry

Of spindle and loom,

And the great wheel that toils amid the hurry

And rushing of the flume.

Born in the purple, and uplifts thy drooping banner,

And round thee throng and run

The rushes, the green yeomen of thy manor,

The outlaws of the sun. 
The burnished dragon-fly is thine attendant,

And tilts against the field, And down the listed sunbeams rides resplendent,

With steel-blue mail and shield.

Thou art the Iris, fair among the fairest, Who, armed with Goldenrod And winged with the celestial azure, bearest

The message of some God.

- H. W. LONGFELLOW. 


\section{BLACK-EYED SUSAN}

Thistle Family

Rudbeckia hirta

Composite Family (Gray)

\section{MAY - SEPTEMBER}

Is fields. Stems simple or sparingly branched, from one to three feet high. Leaves slightly toothed, lanceolate to oblong, lower ones with petioles, upper ones without, narrower, acute. Flower heads two to four inches broad, with from ten to twenty orange-colored ray flowers. Bracts of the involucre hairy, spreading or bent backward, much shorter than the rays. Disk purple-brown, disk flowers perfect, with five lobed corollas. Anthers entire, or with two points at base. Style branching, with hairy appendages. Ray flowers without stamens or pistils, entire or toothed. Receptacle conic or convex with chaffy scales enveloping disk flowers. Akenes four-angled. 


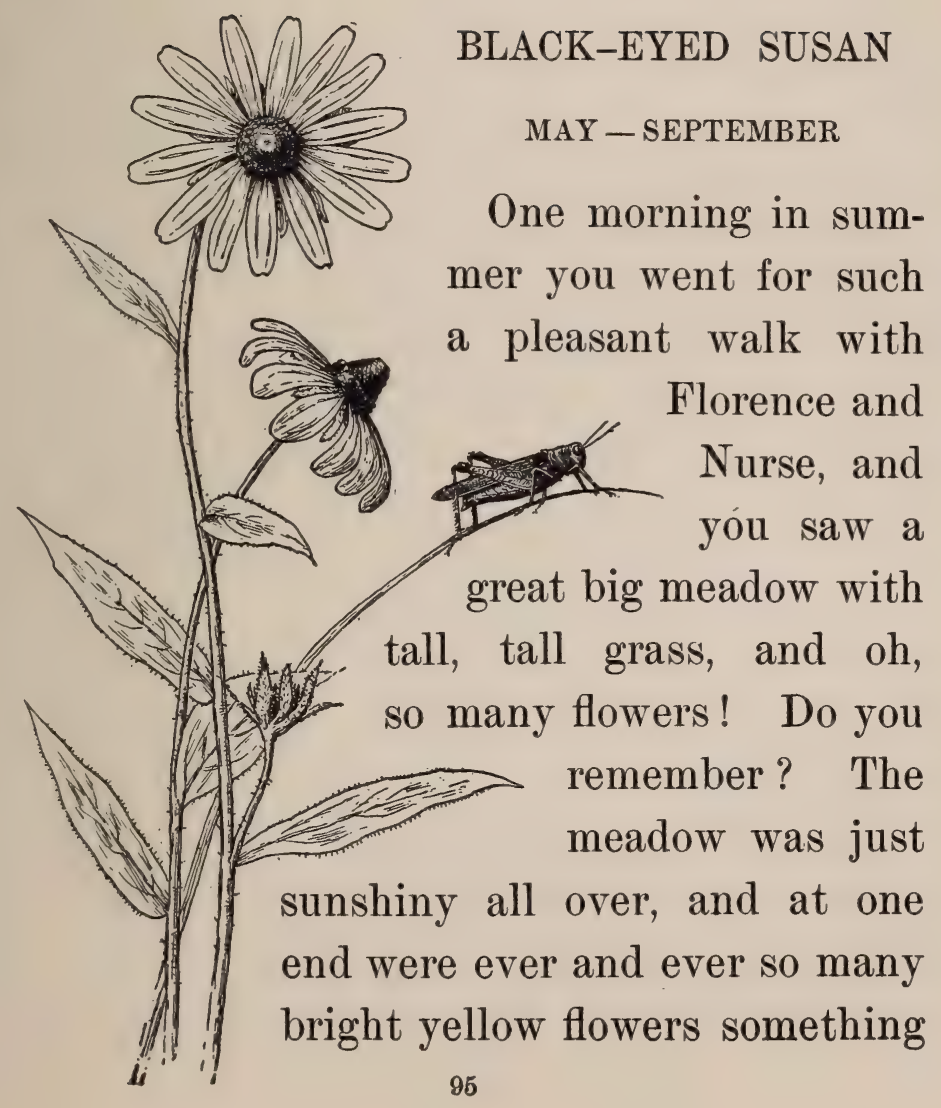


like Daisies, and something like Sunflowers.

You ran and Florence ran, and Nurse let you pick as many as you liked. She told you they were called Black-eyed Susans. How you laughed at the funny name, and you took some of the bright flowers home to show Mother.

Do you remember how she took one and pulled it apart to show you how the big flower head was made up of little flowers? The outside yellow petals were flowers, each of them, and the big brown centre, too, was a mass of little flowers all closely packed together. Mother told you that flowers arranged like this belonged to a big family called Composite or Thistle. 


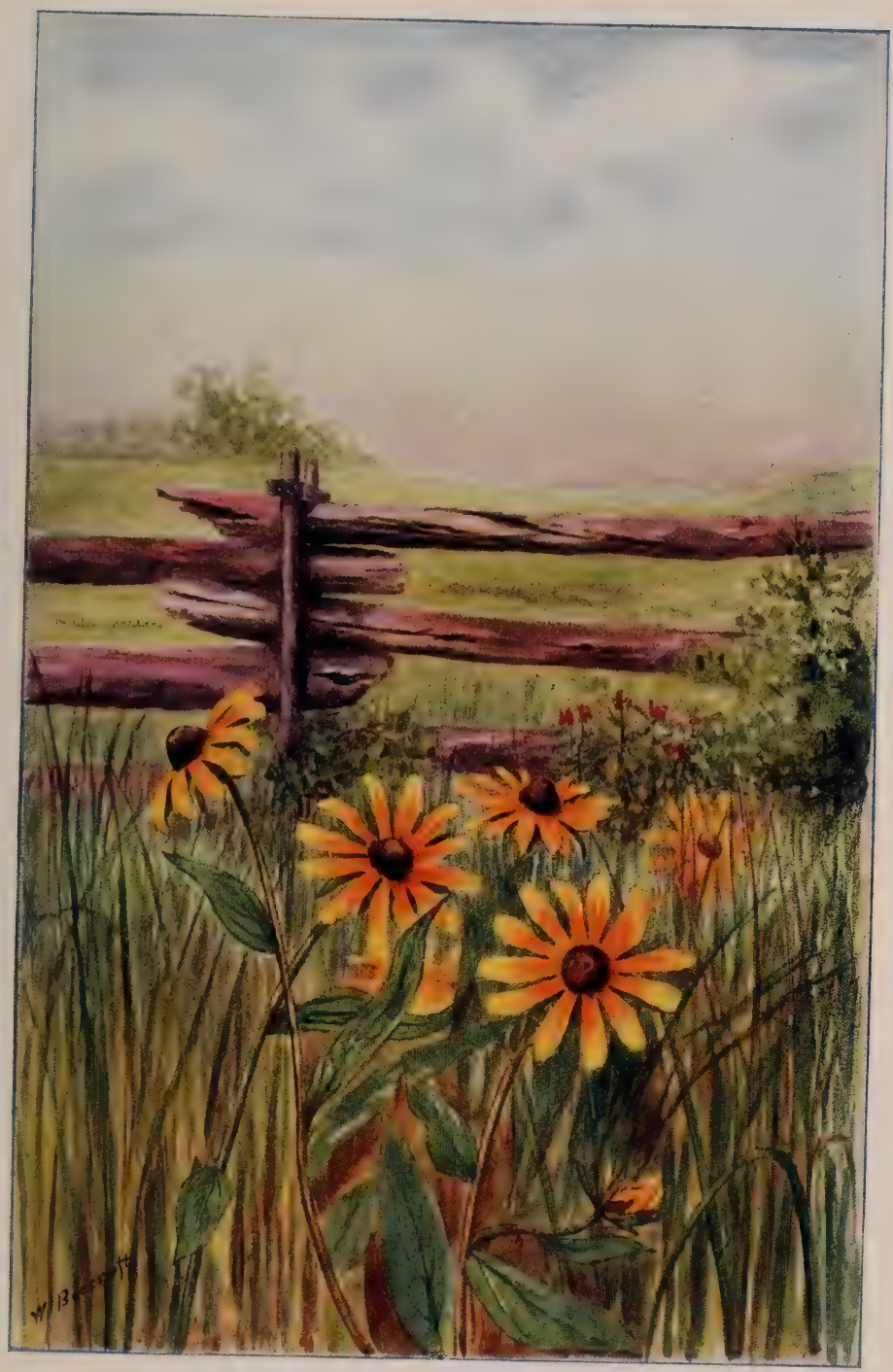

BLACK-EYED SUSAN 



\section{BLACK-EYED SUSAN : CONE FLOWER}

Merry, laughing Black-eyed Susans grow along the dusty way,

Homely, wholesome, happy-hearted little country maids are they.

Frailer sisters shrink and wither, 'neath the hot midsummer sun,

But these sturdy ones will revel till the long, bright days are done.

Though they lack the Rose's sweetness and the Lily's tender grace,

We are thankful for the brightness of each honest, glowing face;

For in dry and barren places, where no daintier blooms would stay,

Merry, laughing Black-eyed Susans cheer us on our weary way.

- Minnie Curtis Wait. 


\section{SOLOMON'S SEAL}

LILY FAMILY

Polygonatum biflorum

\section{$\mathrm{MAY}-J U L Y$}

Wooped banks. Grows from a rootstock on which are scars suggesting the impression of a seal on wax. These scars were left by the separation of stems of previous years from the rootstock. Stem is slender and curving, one to three feet high. Leaves, parallel-veined, without stalks. Flowers in axils of the leaves, nodping, pale yellow, cream white, or greenish. Perianth, six-lobed at end, bell-shaped. Stamens, six with two-celled anthers. The one pistil has a slender style. Fruit, a dark blue round berry, containing a few seeds. 


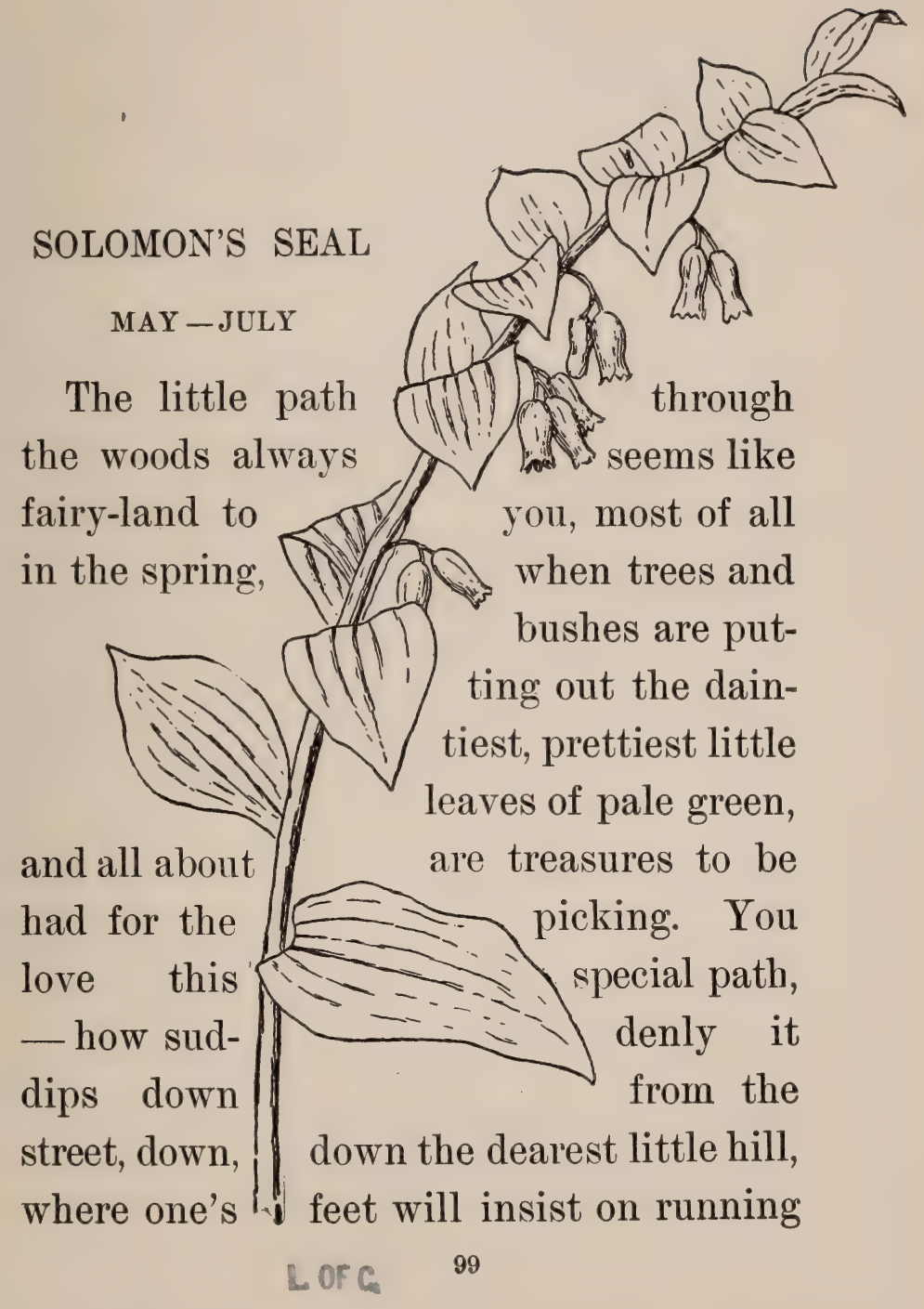


as fast as possible, — and then all at once you are in fairy-land. It is always a joy to come here; but one day you remember above all others, for the flowers seemed to spring up all around and your hands were full before you reached the little marshy spot that one crosses before coming to the hollow tree. This was the day you first found Solomon's Seal growing in the woods, though you had often seen it in Grandmother's garden, _ and truly had not cared much for it. Here in your enchanted path it seemed like a chime of fairy bells, and you almost thought you could hear the music.

The small bell-shaped flowers were of a yellow or cream color, and hung down beneath the leaves in clusters of twos. How gracefully the stem bent with their weight! You brushed your fingers gently 
across the bells to see if they really would make music, - but it must have been fairy music, for you could not distinguish a sound. Oh, if you were only like Puck, with sharp pointed ears, and could come to this treasure-house late at night, what music you would hear !

You wonder why this plant is called Solomon's Seal, and are told of a resemblance on the rootstock to the impression of a seal on wax. Then you want to know why it is Solomon's Seal, and when no one can tell you just why, you are more sure than ever that grown-ups are very stupid - a suspicion that has lurked in your mind for a long time. You never give names to things without a good reason, perfectly explainable; but you think grown-ups must just give names because things have to be called something. 


\section{ST. JOHN'S WORT}

\section{JUNE - SEPTEMBER}

A troublesome weed in fields. Spreads by runners from the base. The stems are upright, branching. Leaves are opposite, without petioles, small, with pellucid or translucent dots. Flowers quite large, yellow, growing in leafy cymes. The calyx has five lance-shaped and pointed sepals. The corolla is of five yellow petals dotted with black, twice the length of the sepals. There are many stamens. The pistil has three spreading styles. Pod is three-celled, with many seeds. 


\section{ST. JOHN'S WORT}

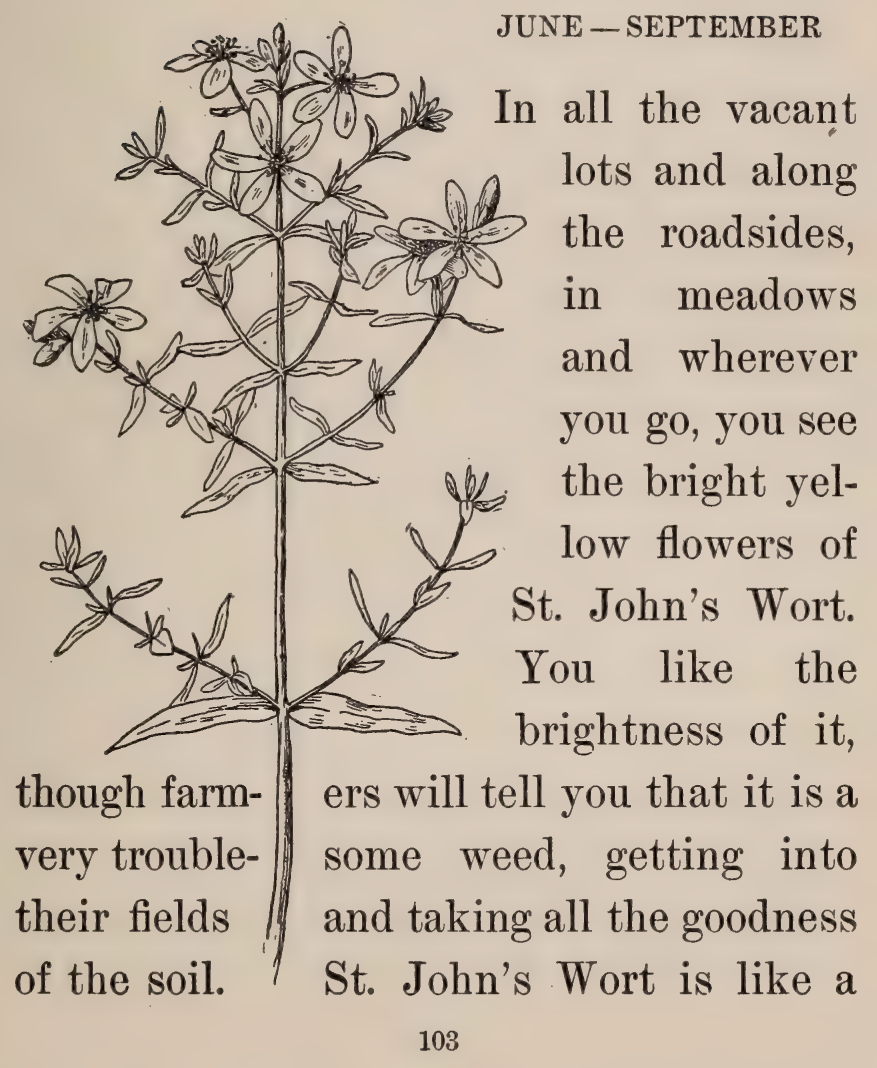


tramp from over the seas, and a most persistent one, as he wants full possession wherever he takes root, and crowds out plants that are perhaps more desirable. How proudly and almost insolently he stands, sending out branches in every direction and lifting up his clusters of yellow flowers as though they were the most beautiful things imaginable.

There are many stories told about this otherwise uninteresting plant. Once it was thought to keep away evil spirits, and it was also used as medicine. It does not appeal to your imagination much, and you would scornfully refuse to include it among the flowers in your hand, but you like to see the yellow flowers along the road as you drive by. You wonder how it spreads all over a field in such a short time, spilling over, as it seems, into the 
road itself. You are told that under the ground are runners spreading out busily to start new shrubby plants, and as each one sends out several runners you can see that it would not take long for a field to be covered with St. John's Wort. Wouldn't you like to take a look under the ground and see all the roots of trees and plants, the runners and hidden flowers, and the homes of animals and insects that live below the surface of the ground? Some of these underground homes are most wonderful. No doubt you have seen pictures of ants at work making their marvellously constructed dwellings, and have read about them. We should be much astonished at the size of tree roots, I am sure, if we could see below the ground as well as above. 


\section{WILD ORANGE-RED LILY: WOOD LILY}

LiLY FamiLY

Lilium Philadelphicum

\section{JUNE-JULY}

Found in woods. The lilies grow from a bulb. The stem is one or two feet high, leafy. Leaves are lance-shaped, in whorls of five to eight. The flowers are red or orange-red spotted with purple, open bell-shaped, large, erect, at end of stem. The perianth is of six divisions, widely separated and on slender claws, honey-bearing groove beginning at base. There are six stamens with long, narrow anthers, attached at one point so that they swing to and fro. Pistil has a long style and three stigmas, or lobes to the style. Pod is oblong, packed with two rows of flattened soft-coated seeds in each cell. 


\section{WILD ORANGE-RED LILY}

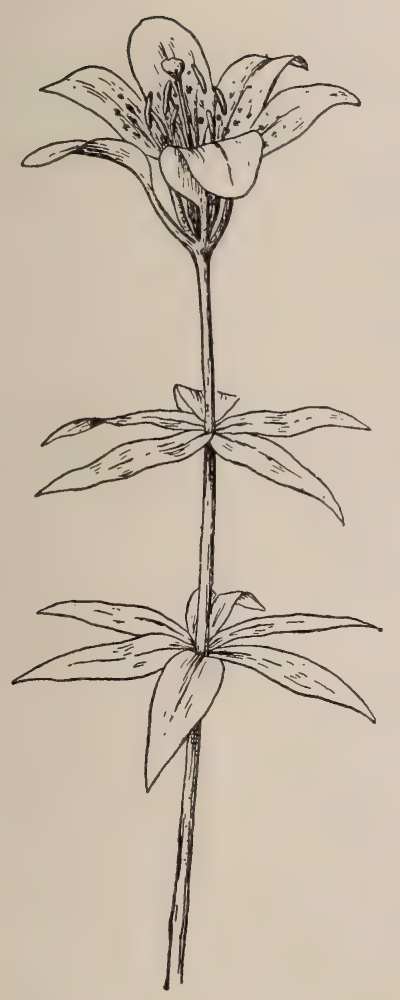

JUNE-JULY

Up and up the steep mountain path you had climbed, and your feet just ached, and you were so tired and thirsty, it seemed as though you could drink a whole river dry. You really thought the mountaintop must be miles and miles up in the sky, almost up to the moon. Mother had hesitated about let- 
ting you take the long walk, but finally was persuaded after you had told her how big and strong you were, and showed her how easily your feet could climb. Now you almost wished you had stayed at home with Nurse, - when all at once, through the dearest little opening in the woods, you saw a group of the most beautiful Red Lilies, like a gleam of fire against the dark green of the trees. How your heart leaped for joy; - your feet forgot to be tired and you ran as fast as you could to get nearer to these treasures. Joy of joys, near at hand was the most enchanting little spring bubbling up _ it looked as though the water came right out of the rock, and how deliciously cold it was! Wasn't that the best drink of water you ever had, and didn't you thank the Lilies for showing it to you? 


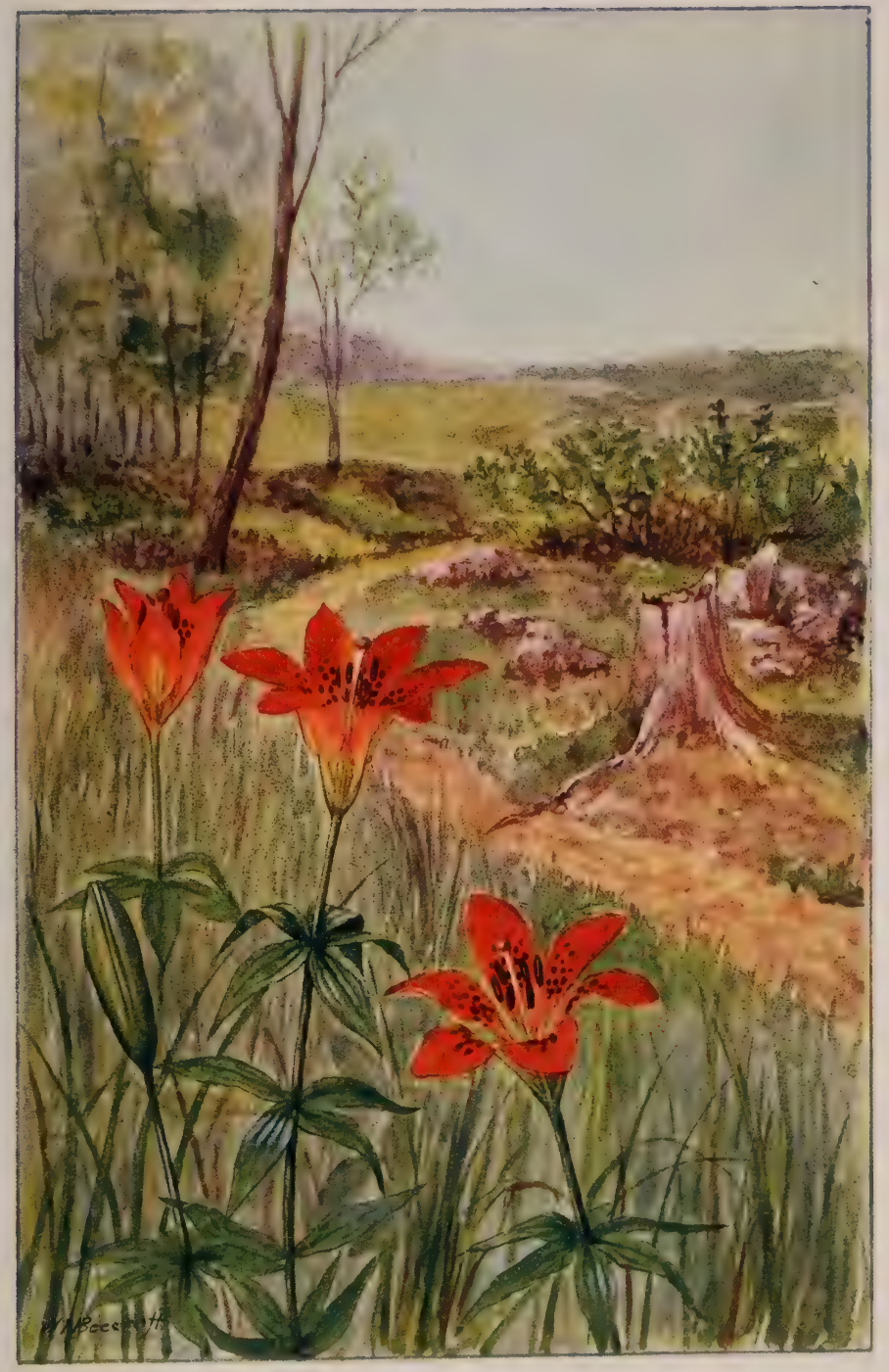

WILD ORANGE-RED LILY 

How carefully you picked two or three of the Lilies to take home. You loved the bright orange-red color, it made you think of a flame, and you thought it very beautiful to be dotted with dark purple spots, - this combination of color delighted your eye. Since that day you have often found Wood Lilies, and they always give you a feeling of joy.

You notice that the perianth, or outer part of the flower, has a curious way of narrowing down toward the lower part. You are sure that the Lilies in your garden are not like this, — but they are unlike in color, too. The whorled leaves of Wood Lily are interesting to you. You imagine that they are playing "Ring-around-a-rosy" around the stem, and you spin the stem in your hands to make them go faster. 


\section{DOGBANE}

\section{Dogbane Family Apocynum androsamifolium \\ JUNE - JULY}

Grows along thickets. Branches forked and widely spreading, with very tough fibrous bark, juice milky, sticky. Leaves opposite, somewhat egg-shaped, with short petioles or leaf-stalks. Flowers small, pink, veined with a deeper pink, fragrant, growing in loose clusters at the ends of branches. Corolla bell-shaped with five spreading lobes. Calyx, five-lobed, small. There are five stamens attached to the base of the corolla. Pistil without a style, stigma large, egg-shaped. The seeds have a long tuft of silky down at one end. They are in long and slender pods, each of which contains many seeds. 


\section{DOGBANE}

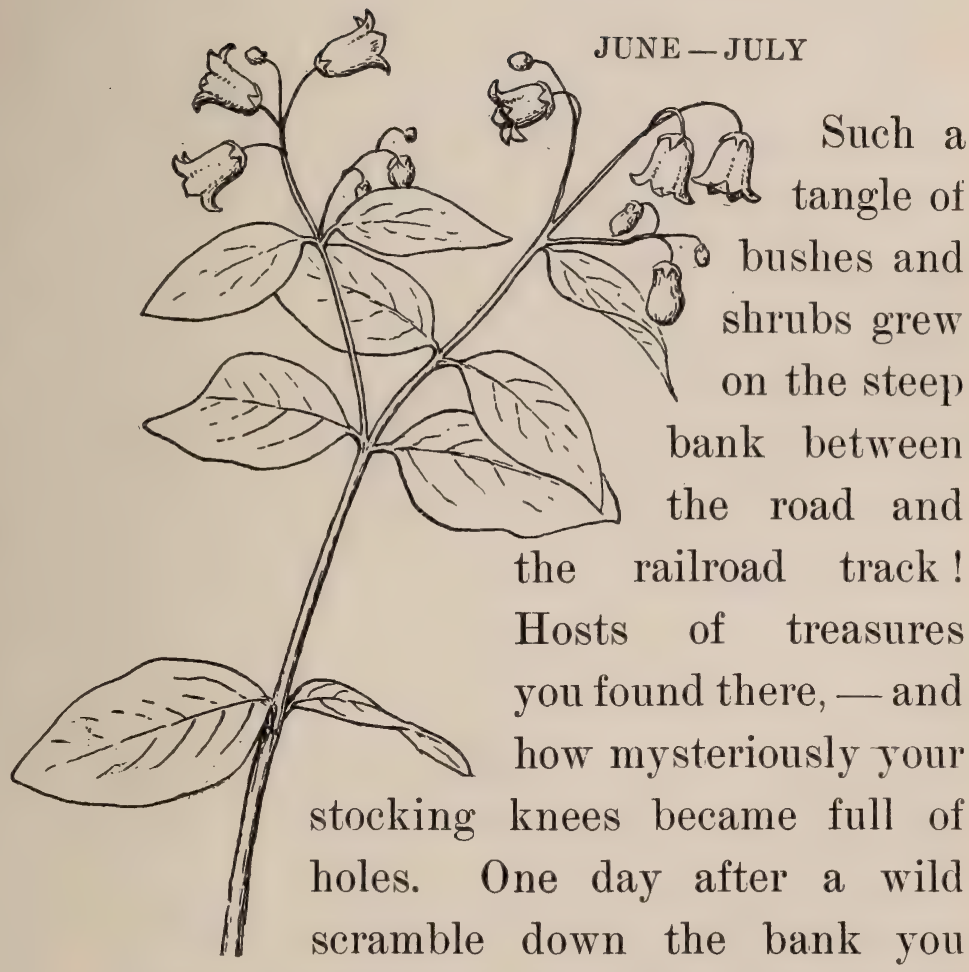

discovered some lovely little pink flowers 
growing in loose clusters on a high plant which was still not quite a bush. Each flower was like a pretty little bell the color of a rose, veined so delicately with a deeper pink. To your delight they were fragrant as well as pretty - treasures indeed. You carefully picked a long branch to take to Mother, and found that your hands were sticky with the milk-like juice from the stems. Nevertheless, you bore your precious find safely through the tangle of bushes, and were all eagerness to know its name. Surely such a delight as this should have a beautiful name like "Aurora Borealis," which to your fancy had the most enchanting sound - it was so hard to say. How surprised, and, it must be confessed, disgusted you were to hear that your treasure went under the name of Dogbane. 
It was disappointing, but when you were told that once the plant was considered poisonous to dogs, you saw the reason for the name, and resolved to keep your little dog, Gipsy, away from these flowers. How anxiously you watched him all day after finding the pretty blossoms of Dogbane, for he might have gone too close to the plant. You told your fears to Mother, who soon reassured you, and told you not to be afraid, for Gipsy would know better than to eat these flowers. Then you rejoiced once more in the fragrant pink bells. 


\section{WATER-LILY}

WATER-LiLY FAMILY

Castalia odorata

Nymphaea odorata

JUNE - SEPTEMBER

IN ponds and slow streams. The rootstock is thick, simple, or with few branches. The leaves are floating, circular in shape, or nearly so, cleft on one side, green and shining above, purple or red beneath. Petioles and peduncles are slender, with four main air channels. The flowers are white or tinged with pink, broad. The calyx is of four sepals, green outside and white within. The corolla is of many petals, gradually passing into stamens. The stamens are numerous, the outside ones with large petal-like filaments and short anthers, the inside ones with long and narrow filaments and longer anthers. The pistil is compound. The fruit ripens under water. 


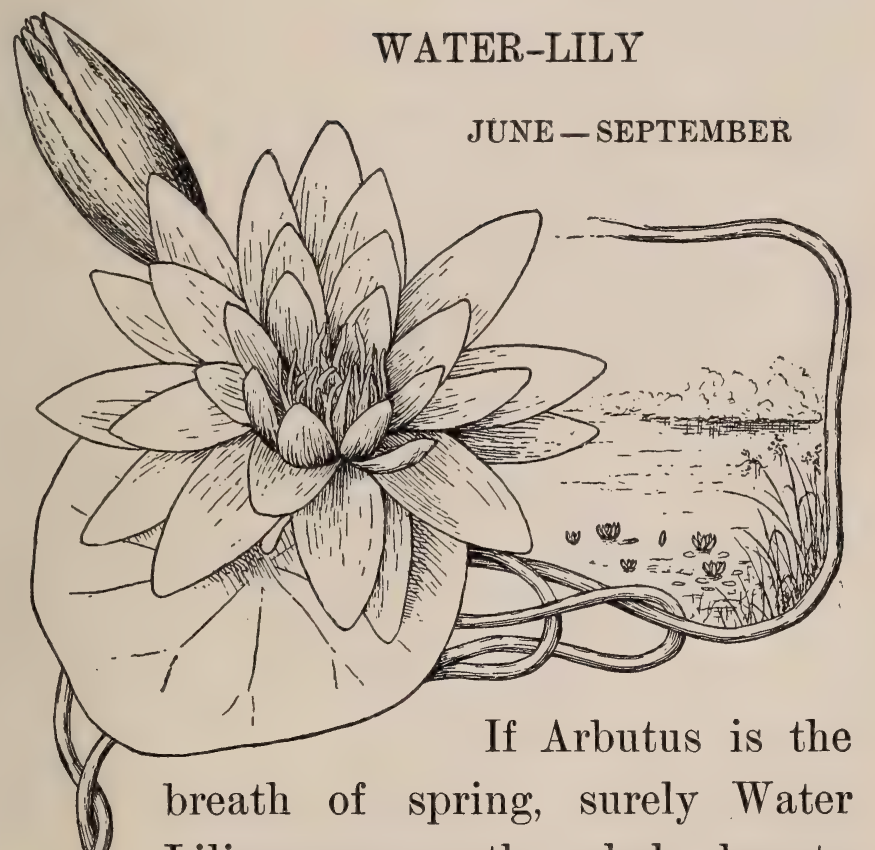

Lilies express the whole beauty of summer. Can you ever forget the pond dotted here and there with the big white beauties? Pure as the 
whitest snow, with fragrance that seems the most delightful thing in the world, they fill you with happiness. You stretch out your little arms and would gather them all. No matter how much selfrestraint one exercises in regard to other flowers, it is almost impossible to leave a pond where the Lilies grow, without capturing every one of the lovely things. "Water Nymphs" they are sometimes called, - isn't it a good name for them? How gracefully they seem to float on the surface of the water, surrounded by many flat round leaves, or pads, which look as though they were made of wax. Did you ever notice that these pads are red or purple underneath instead of green?

What long, long stems they have, like hollow rubber tubes. When you pick the Lilies you have to put your hand way down 
in the water, and then the stems are not easy to break. How proud you are to take a handful of these lovely blossoms to Mother! You discover that they go to sleep in the afternoon, but the next morning they are awake again and wide open to catch all the sunlight, and you linger orer them lovingly, drinking in their pure beauty and delicious fragrance.

\section{A WATER-LILY}

The queen of the fairies, I do believe, Crossed over the brook on midsummer eve,

For here in the rushes she left afloat Her little, wee, ivory, gold-lined boat. 


\section{FIREWEED}

Evening Primrose Family

Chamcenerion angustifolium

(GRAY) Epilobium angustifolium

\section{JUNE-SEPTEMBER}

Found in dry soil, often very abundant after forest fires. Erect, rather stout, sometimes branched. The leaves are alternate, with very short petioles, lance-shaped, sharp pointed at tip, narrower at base. The flowers are pink-purple, growing in long racemes at top of the stems. The four calyx parts drop off before the fruit ripens. Corolla is of four petals, spreading, broadest across the middle, or above. There are eight stamens, with anthers oblong, and filaments larger at the base than at the top. The united styles of the pistil are slender; the stigma is four-lobed; the seeds are smooth, numerous, and have a long coma or tuft of hairs at one end. 


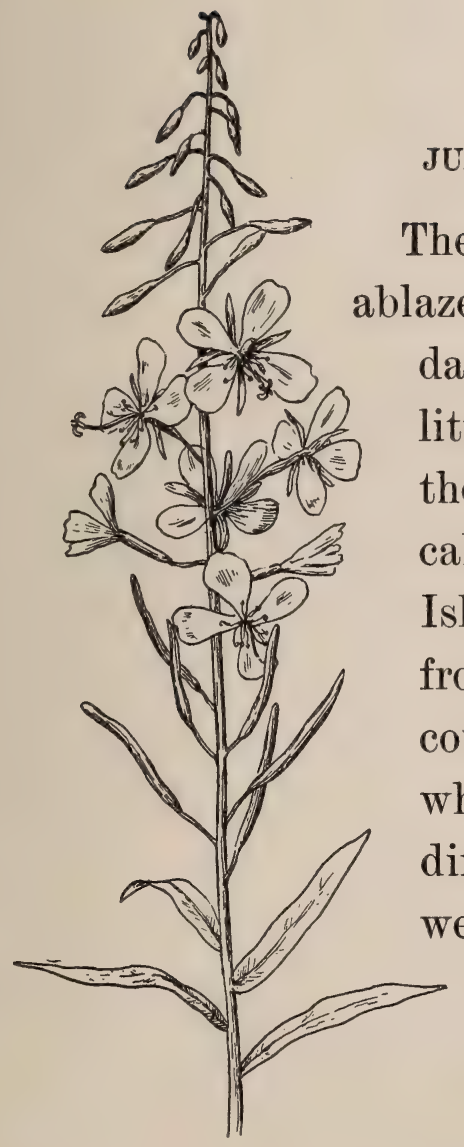

\section{FIREWEED}

JUNE - SEPTEMBER

The meadows were day that you took the little sail-boat across the bay to what you called the "Enchanted Isle." As you looked from the boat you could not imagine what these tall nodding masses of flowers were, and you were most eager to land so that you might find out. 
The little island where these meadows were was such a delightful place, one always felt like Robinson Crusoe or Christopher Columbus on exploring expeditions - and how many curious things and wonderful treasures were to be found there! The land sloped gently back from the dearest little pebbly beach, on which, by the way, you found strange jewels of richest, rarest colors, more precious to you than diamonds or rubies. The meadows beyond soon lost themselves in an enchanted forest, the home, you were sure, of numbers of giants, elves, and strange beings, marvellous to dream about, but dreadful to think of meeting.

These woods had recently been partly burned, and now in the path of the flames, and indeed all through the meadows, were masses of Fireweed. Strange 
that you had never discovered this plant before; but then, one made new discoveries at every visit to the island. You did not care for the flowers to take home, as they did not look nearly as pretty when you stood close beside them, but you were interested to see how many flowers grew in the long raceme, those in full bloom at the bottom and buds of all sizes above. It seemed to you like a flame, beginning at the lower part and sweeping upward, dying out below as it reached the top. The color of the flowers did not please you; you would much have preferred a bright scarlet or orange to this peculiar purplish pink. You like the name of Fireweed better than the one that this plant is often called, - Willow Herb, though you are struck by the resemblance of the leaves to those of the willow tree. 


\section{MILKWORT}

Milkwort Family (Gray)

Polygala viridescens

Polygala sanguinea

\section{JUNE - SEPTEMBER}

Found in fields and meadows. Stem somewhat angled, erect, six to fifteen inches high, smooth, leafy, branching above. There are no leaves at base; the stem leaves are oblong or linear oblong, with a very small point. The flower-heads are round, becoming oval, rounded at end. The flower-stalks are short, flowers rosepurple. The sepals are very unequal, the two side ones, called wings, large and like petals; the other three small, two on the lower and one on the upper side of the blossom. The corolla is of three petals united into a tube which is split on the back. There are eight or six stamens. The seed is hairy. 


\section{MILKWORT}

\section{JUNE - SEPTEMBER}

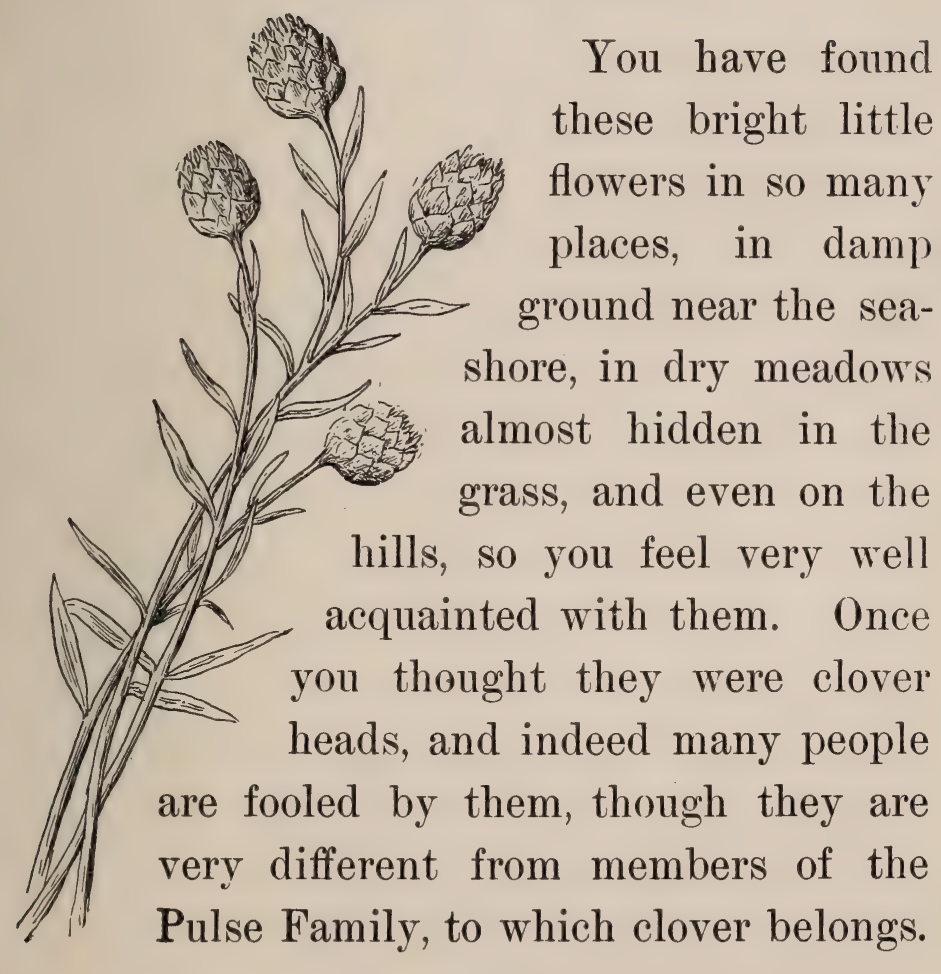


The flowers of Milkwort are extremely difficult to understand, the construction is so peculiar, but look carefully at them; some day you will perhaps want to know them better.

There is one meadow where you always find Milkwort in great profusion all summer, beginning with the time of the Daisies and lasting until the cool days, when Gentian opens its fringed lashes and peeps up at the sky. You love the little blossoms of the Milkwort, though they seldom form a part of the bouquets you gather for Mother. They seem so much prettier to you in the grass, adding a touch of delicate color here and there. Sometimes they are quite a bright pink, but you have found them also in varying shades of pinkish purple, and even almost white. You sometimes find smaller blos- 
soms which you are sure must belong to the same family, though they look like the baby brothers and sisters of Milkwort.

A cousin which you often find along sandy roadsides is very well known to you by sight, though you wish it had another name besides Polygala Polygama, which is very long for such little flowers, and very hard to say. The flowers of this dainty plant are of a pretty, delicate, purplish pink, growing in a raceme at the top of the stem. Besides these flowers are some below the ground, that we cannot see, of course, and that are not attractive to look at, but very useful to the plant. These hidden flowers are called Cleistogomous; that is a long name for very small flowers, isn't it? 


\section{WILD CARROT}

Carrot Family

Daucus carota

Parsley Family (Graỳ)

\section{JUNE - SEPTEMBER}

Found in fields and waste places. Root fleshy, deep, conic. Lower leaves many times divided into long and narrow parts, upper leaves smaller, less divided. Involucre of several leaflike bracts, involucels of many entire or toothed bracts. Flowers in compound umbels, two to four inches broad, rays numerous, crowded, inner ones shorter than the outside ones, very slender flower-stalks. Flowers white, central one of each umbel often purple or red. Petals obovate, with tips bent inwards. Five stamens, and two styles to the pistil. Umbels very concave, like birds' nests, in fruit. Fruit covered with bristly prickles. 


\section{WILD CARROT}

JUNE - SEPTEMBER

"Birds' nests" you called them, and were very much astonished and even indignant when one day some one told you that these flower friends were a great nuisance in the fields. You thought that every one ought to love the lace-like flower clusters just as you did. The halfclosed ones are your

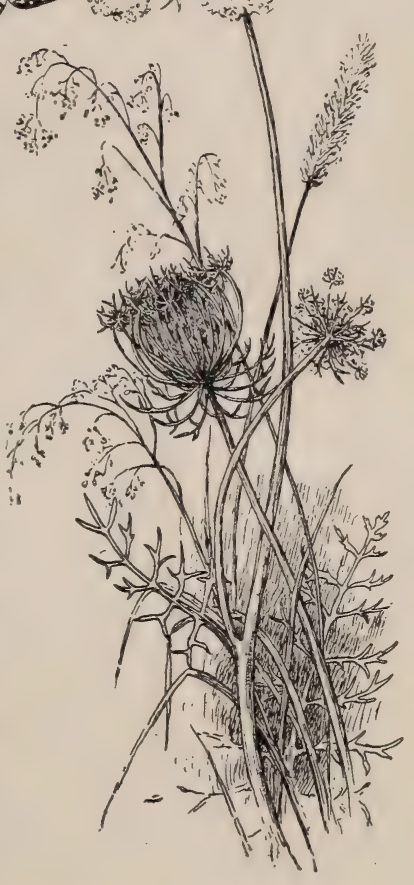


special delight, for they do look like birds' nests. Long hours you have spent playing with them, filling shrubs and bushes with the dainty little nests, hoping that some bird would come and make one of them his home. Did you ever look closely at the flower clusters? How many tiny flowers it takes to make one big "Umbel," as this flower arrangement is called. Indeed the whole is formed from little "Umbellets" consisting of many flowers. In the centre is a tiny dark red flower oftentimes. What dainty lace parasols these would make for the queen of the fairies!

The leaves are finely cut, too, and made up of many leaflets. Wild Carrot is the name we most often hear for these flowers, though they are sometimes called Queen Anne's Lace, and sometimes Birds' Nests. 


\section{WILD CARROT}

In the fields and blooming meadows

Among the grasses green,

And the dainty pink-faced clover,

Fair ladies can be seen,

Decked out in snowy laces,

Heirlooms of nature old,

"They've long been in the family,"

Flower gossips have been told.

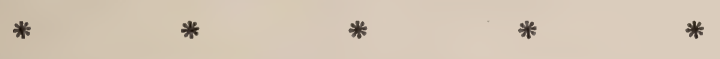

Gauzy gowned in fairy network

And caps of finest lace,

Dames colonial of the roadside

In the summer find a place,

In nature's glad procession,

That pay all homage due

To their wise and bounteous mother,

They're proud and loyal too!

- Ray Laurance. 


\section{BOUNCING BET}

Pink Family

Saponaria officinalis

ALL SUMMER

Found along roadsides, waste lands, and in gardens. It is rather a stout herb, smooth, from one to two feet high. The leaves are three to five ribbed, the lower ones oval, or egg-shaped, the upper ones lanceolate, or lance-shaped. The flowers are clustered, regular though usually double, pale rose, or white. The calyx is cylinder shaped or oblong, not angled, five toothed. The corolla is of five or more petals, notched at the end. There are ten stamens, and one pistil with two styles. The pod is four-valved. 


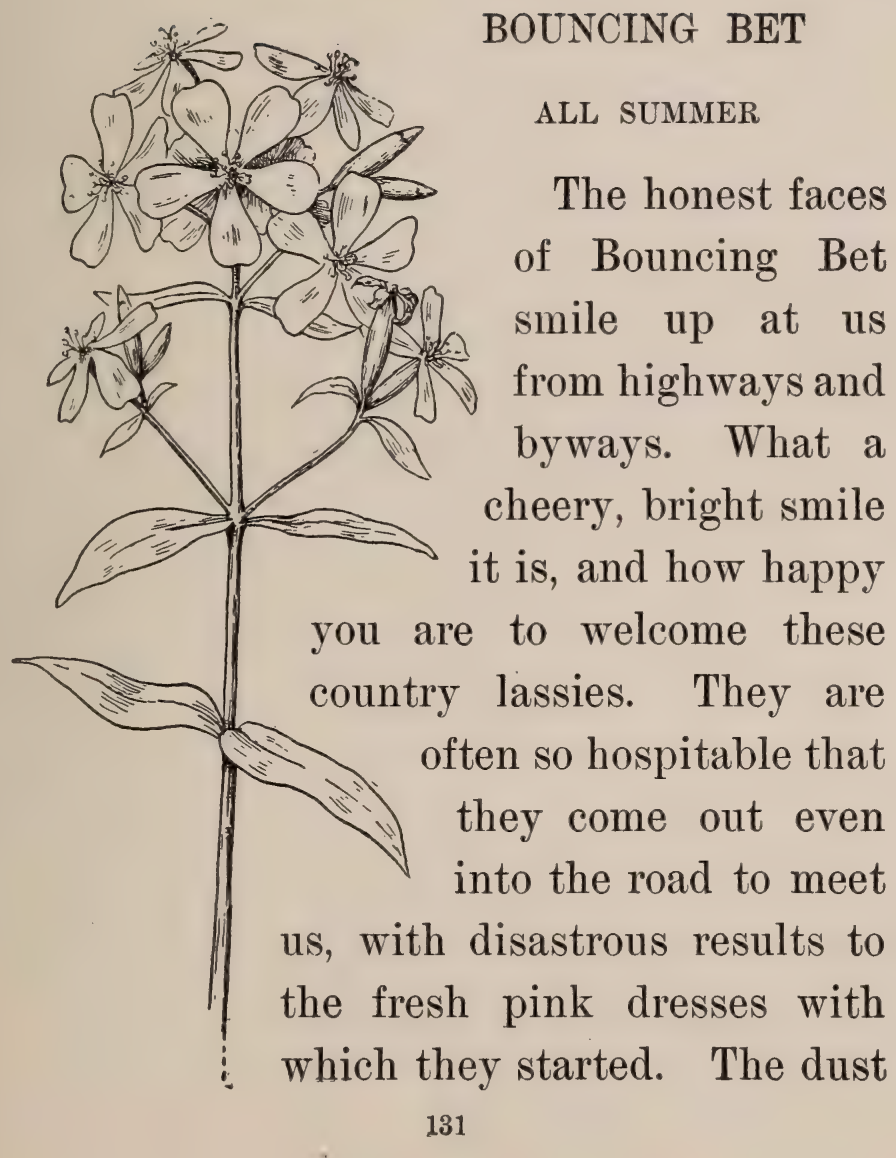


clings to them so that we can imagine their bright cheeks besmirched, and dresses soiled and torn as though they had been making mud pies, and having hilarious games of hide-and-seek among the brambles. All along the roadside you find them, near old houses and farm buildings, and wherever they can find foothold.

Once you found one plant growing all by itself near the road. The flower was very large and important looking, with many petals and very fragrant, almost like a Carnation Pink. You wondered why it had travelled so far from its companions; did it get tired of the games and noisy plays of its sisters and cousins, or did it try to go off by itself, where it could grow bigger, and pretend to be something very different from the common Bouncing 
Bet? Whatever had caused it to leave its cheery companions, there it was standing in solitary grandeur, apparently forgetting its hosts of relatives that were indeed out of sight.

Bouncing Bet has a peculiar juice that lathers like soap, and has been said to take the place of soap sometimes. Strange that with soap right at hand these sturdy maids should allow themselves to get so dusty and soiled, isn't it? But you see they are so hospitable and social that they spend their days close by the road, to smile at all the passers-by. What wonder that the dust from many wagon wheels soon covers them; but it does not make them lose their cheeriness, so you may always be sure of a welcome from these friends. 


\section{WINTERGREEN}

Heath Family

Gaultheria procumbens

\section{JUNE - SEPTEMBER}

IN evergreen and low woods. Long and slender underground runners send up stems three to five inches high. Leaves are alternate, broad, evergreen, spicy, aromatic, and grow at top of stem. Flowers are white, nodding, usually two from the axils of the leaves. The calyx is small, five-lobed. Corolla, oblong or urn-shaped, with five small lobes at the end. There are ten stamens with anthers opening at the top. One pistil. In fruiting, the calyx becomes thick and fleshy, so that it looks like a berry, but has a dry pod inside, containing many seeds. 


\title{
WINTERGREEN
}

\author{
JUNE - SEPTEMBER
}

All around you in the pine woods the ground seemed carpeted with these shiny green leaves. You stopped to pick a few, and found some bright red

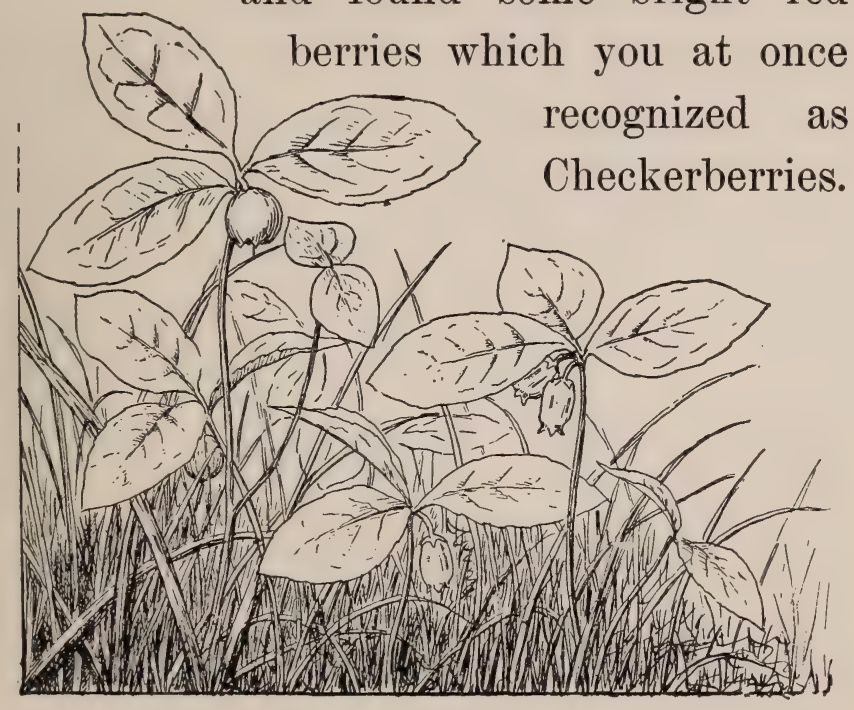


What delight it was to find them growing! They tasted so much better to you there in the woods than ever before. For the first time you noticed that each berry had a five-pointed star on top of it. "What made it?" you asked Mother, and were told that it was formed by the points of the calyx, or outer part of the flower, which had thickened and turned into this pretty red berry. Close at hand were some of the white blossoms, and you looked hard at them, wondering how long it would be before they, too, became red beiries.

Another day you were walking along a little hill where the ground was quite sandy and rocky, and again you saw the little Wintergreen plants. By this time you felt that they were old friends, and were sure that you would recognize the 
leaves, flowers, or berries wherever you saw them.

The little reddish green leaves have such a delicious flavor; but you discover that the big green ones are quite tough and hard, and sometimes bite your tongue, they are so strong and spicy. It is from these leaves that the oil of Wintergreen is extracted. You know the flavor of Wintergreen very well, don't you, as it is often used in candy? It is sometimes used as a medicine, too. One of the cousins of Wintergreen is a very dear friend of yours, the Arbutus. Wintergreen is an evergreen, too, and belongs to the Heath Family. 


\section{INDIAN PIPE}

Indian Pipe Family

Monotropa uniflora

\section{JUNE - AUGUST}

Found in rich woods. Parasitic, feeding on roots of other plants. No green foliage, stem white, like wax, with bracts in place of leaves. Flowers waxy-white, nodding, one at the top of each stem. Calyx of two or more bract-like scales, which fall off before the seeds ripen. Corolla of five white petals, wedge-shaped, looking like the bracts of the stem. There are ten stamens with anthers opening across the top, and one pistil, with a thick style, and stigma like a disk, somewhat depressed. The pod is four-or five-celled, with tiny seeds looking like fine sawdust. 
INDIAN PIPE

\section{JUNE-AUGUST}

Once when you were walking through the woods you came suddenly upon a group of these pale, ghostlike plants. You hardly believed they were growing, but in your eagerness to see, broke some of them off. To your horror the delicate white things began to turn black before you could get back to ask Mother
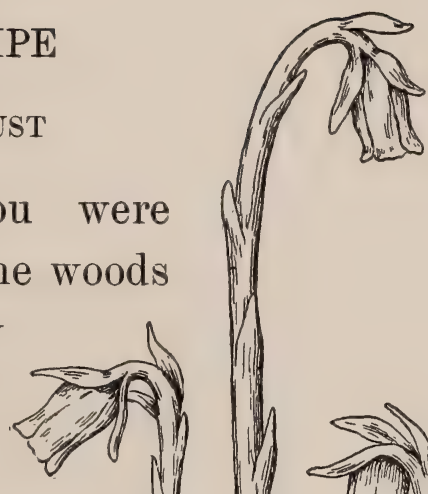
and they felt so cold and dead in your hand that you did not like them. Once you picked up a little toad and he was cold, too, but it was a nice, live coldness, not like these curious plants. They had a queer coldness about them that made shivers run down your back, and you had no desire to pick any more. You wonder what makes them so white and cold; if once they were pink or blue and nodded in the bright sunlight; if they were naughty and were sent into the dark woods for punishment, where the sun could not reach them; did their pretty color leave them, and did they then grow white and stiff, like pipes made of ivory?

You remember that Arbutus, when it grows under the leaves away from the sunlight, is whiter than that which grows 
in the open, and you mean sometime to try planting the Indian Pipe in your little garden to see if it will come up blue or pink, and not be so cold.

You think that a summer spent on the beach might do these pale flowers good, too, when you remember how brown you looked at the end of last summer. You try to imagine how the Indian Pipe would look if it were as sunburned as you were when you came home from the beach. Wouldn't it be funny to find a whole row of little brown pipes growing in the sand? 


\section{MILKWEED}

Mrlkweed Family (Gray)

Asclepias Syriaca

Asclepias Cornuti

JUNE - AUGUST

Fields and waste places. Stem stout, usually simple, three to five feet high, downy. Leaves are oblong, ovate, or oval, spreading, with stout petioles. Flowers in umbels, greenish purple. Calyx with very short tube or none, its lobes separate or overlapping in the bud. Corolla fivelobed or five-cleft. There is a five-lobed or parted crown between the corolla and stamens. Each hood of the corona or crown has an incurved horn inside. Five stamens with filaments joined to the corolla near the base. Pistil with very thick stigma. Pod or follicle contains many flat seeds, each with a coma or long tuft of down attached to one end. 


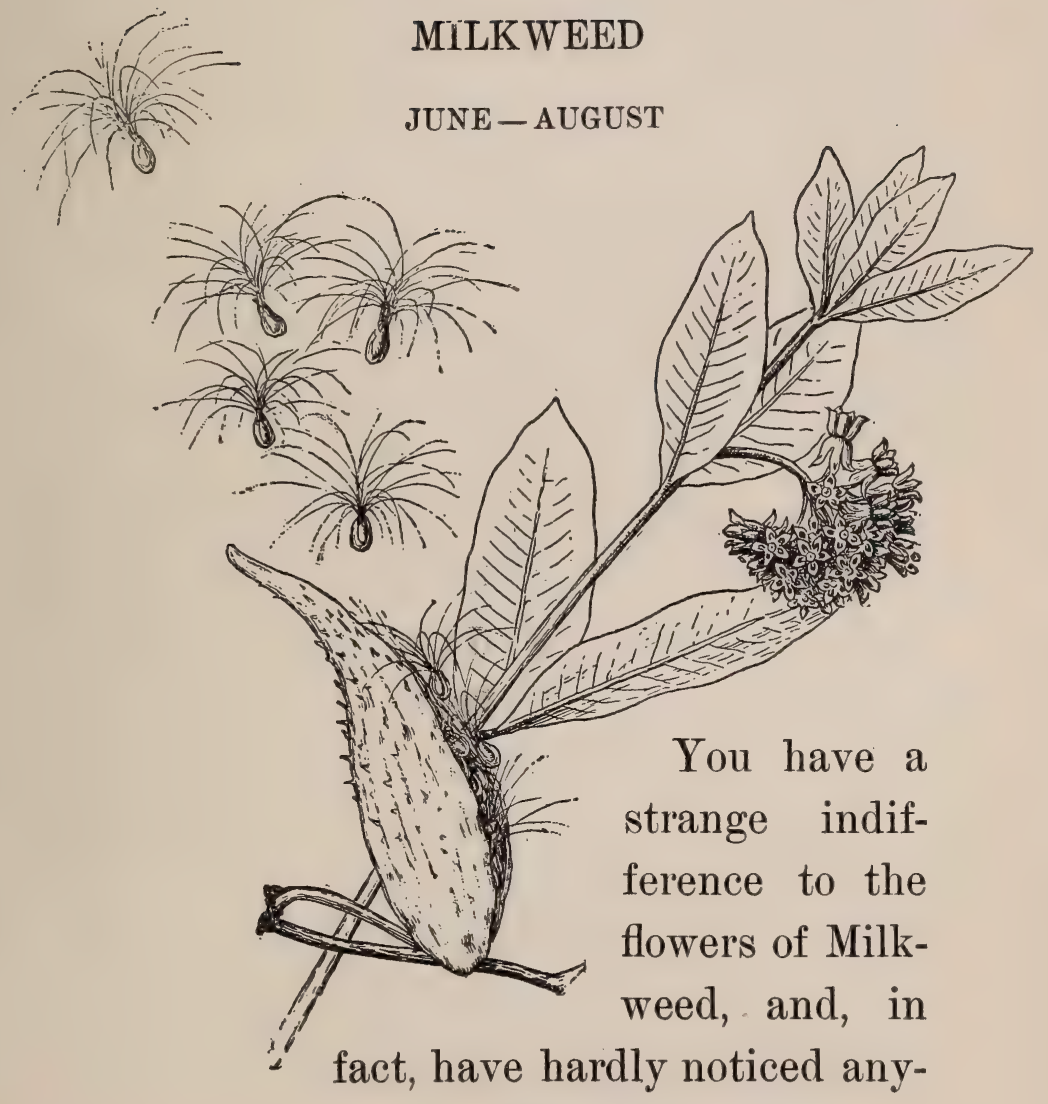


thing about them except that they grow in large clusters, so heavy that they always seem drooping. Haven't you seen how fond the bees appear to be of these flower masses? They are really very interesting if you look closely, though botanists tell us that the flowers of Milkweed are hard to understand unless one has studied a long, long time. The stamens are arranged in such a way that when bees and insects go to the flowers for honey, they carry off the pollen in what seem like tiny, tiny saddle-bags, formed of two masses of pollen joined by the finest of threads. Can't you imagine the bees going shopping for more honey, and leaving these funny little bags of pollen in payment at the next flower "market"? This is exactly what they do, and I am sure you will watch 
eagerly the next time you see bees buzzing about the Milkweed.

The pods of Milkweed are your dear friends already, aren't they? How often you have gathered them, getting your hands sticky with the milky juice, but rejoicing in the lovely silky fluff found inside, In your own mind you were sure long ago that here the fairies found gossamer of which to make new wings, or to repair their old ones when they were slightly torn among the brambles through which the fairies must sometimes have to go. 


\section{MILKWEED}

Little weavers of the summer,

With sunbeam shuttle bright,

And loom unseen by mortals,

You are busy day and night,

Weaving fairy threads as filmy

And soft as cloud swans, seen

In broad blue sky-land rivers,

Above earth's fields of green.

Your treasures you are hiding

In emerald velvet pouch,

You like no curious mortals

To gaze on them, I vouch ;

But your woven fairy fabric

And magic spell concealed

In every tiny fibre,

To nature's touch will yield. 
The clasp of pouch unfastened, Each tiny strand takes flight; For they're surely downy feathers Of cloud swans soft and white, That, caught on sunbeams' shuttle, Tho' you deftly wove with care,

Dame Nature has betrayed you, See, they're scattered on the air!

And no doubt the sky-swan feathers, With magic power endowed, Are wafted by the wind fays

Back to the realms of cloud;

That fairy-land enchanting, With rivers blue and deep, $\mathrm{Oh}$, little roadside weavers Who cannot secrets keep! 


\title{
WILD MORNING GLORY
}

\author{
Hedge Bindweed
}

Morning Glory Family

Convolvulus sepium

\section{JUNE-AUGUST}

Fields and thickets, usually in moist soil. Come from slender rootstocks. Stems trailing or twining, three to ten feet long. Leaves with slender petioles, halberd-shaped, acute or taperpointed at top. Flowers, one on each flowerstalk, white with pink stripes, or white. Calyx with five nearly equal sepals, enclosed by two large bracts. Corolla, funnel-formed, the border five-lobed, five-angled, or entire. The stamens are inserted on the tube of corolla. The pistil has a long, slender style and two stigmas. The pod is four-seeded. 


\section{WILD MORNING GLORY}

Hedge Bindweed

JUNE-AUGUST

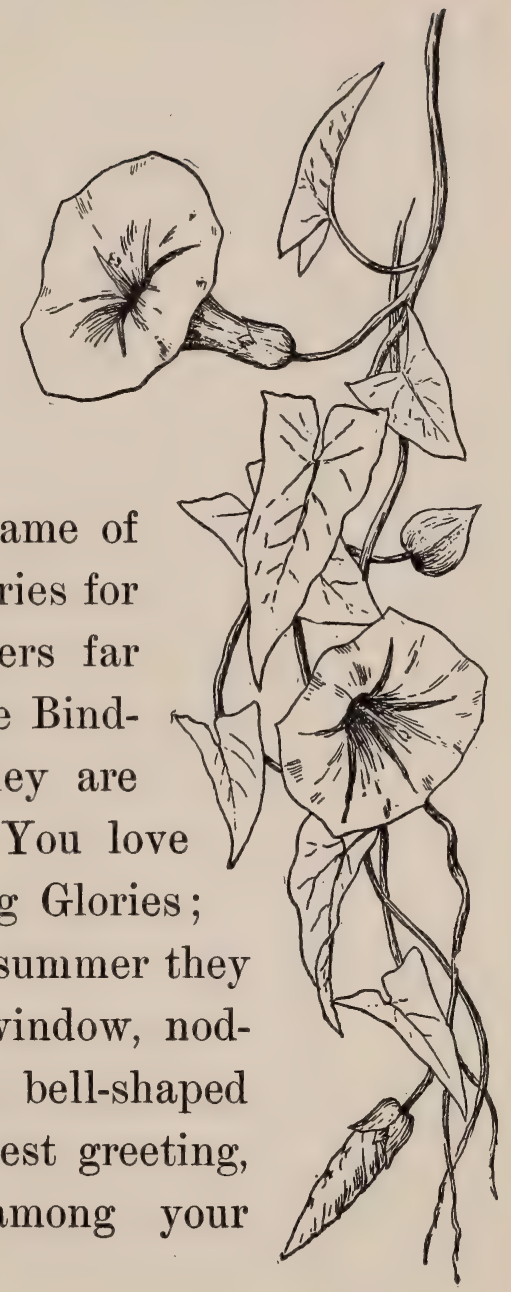

You like the name of Wild Morning Glories for these dainty flowers far better than Hedge Bindweed, the one they are so often called. You love your own Morning Glories; every morning in summer they peep in at your window, nodding their pretty bell-shaped flowers in friendliest greeting, and they are among your earliest friends. 
Their dear cousins, the Wild Morning Glories, you often find growing in waste places, and you love their delicate pink and white blossoms. You notice that the leaves are not just like your Morning Glories at home, which are almost heartshaped, while these are more pointed, like an arrow. You wonder why this is so, and can think of no better reason than that these are wild flowers and perhaps have to have arrows just as Indians and other wild men do, while your own Morning Glories at home are so full of love and happiness that their leaves take the shape of hearts. You like to think that this is the reason, and you have many fancies about Morning Glories that you cannot put into words. How fresh and bright they are every morning, - and how queerly they shrivel up after blooming. 
They almost seem like buds again, but you know they will not bloom, for you have tried to open them, and found that the bell-shaped corolla dropped off instead of blossoming out.

A stone wall covered with Wild Morning Glories is always a delight to you, and you wish you could carry home great handfuls of it to Mother; but the blossoms wilt quickly, and you do not try to pick them now. The stems are very twining and twist round and round so that often they seem braided, but these plants seem much better behaved than their cousin named Dodder, and do not cling to bushes so closely as to take their sap.

Down by the sea you often find great masses of another cousin called European Bindweed, which looks much like the Wild Morning Glories you know so well. 


\section{MULLEIN}

Figwort FamiLy

Verbascum Thapsus

JUNE - SEPTEMBER

VERY common in fields. The stem is thick and woolly, tall. The leaves are oblong, light green, soft and velvety. Flowers grow in a long, dense raceme or spike at top of the stem, and are yellow. The calyx is five-parted, the corolla of five wide, rounded, nearly equal divisions. There are ten stamens, five bearing anthers, all the filaments, or three of them, woolly. One pistil with style expanding and flat at apex. The pod is globular, and contains many seeds. 


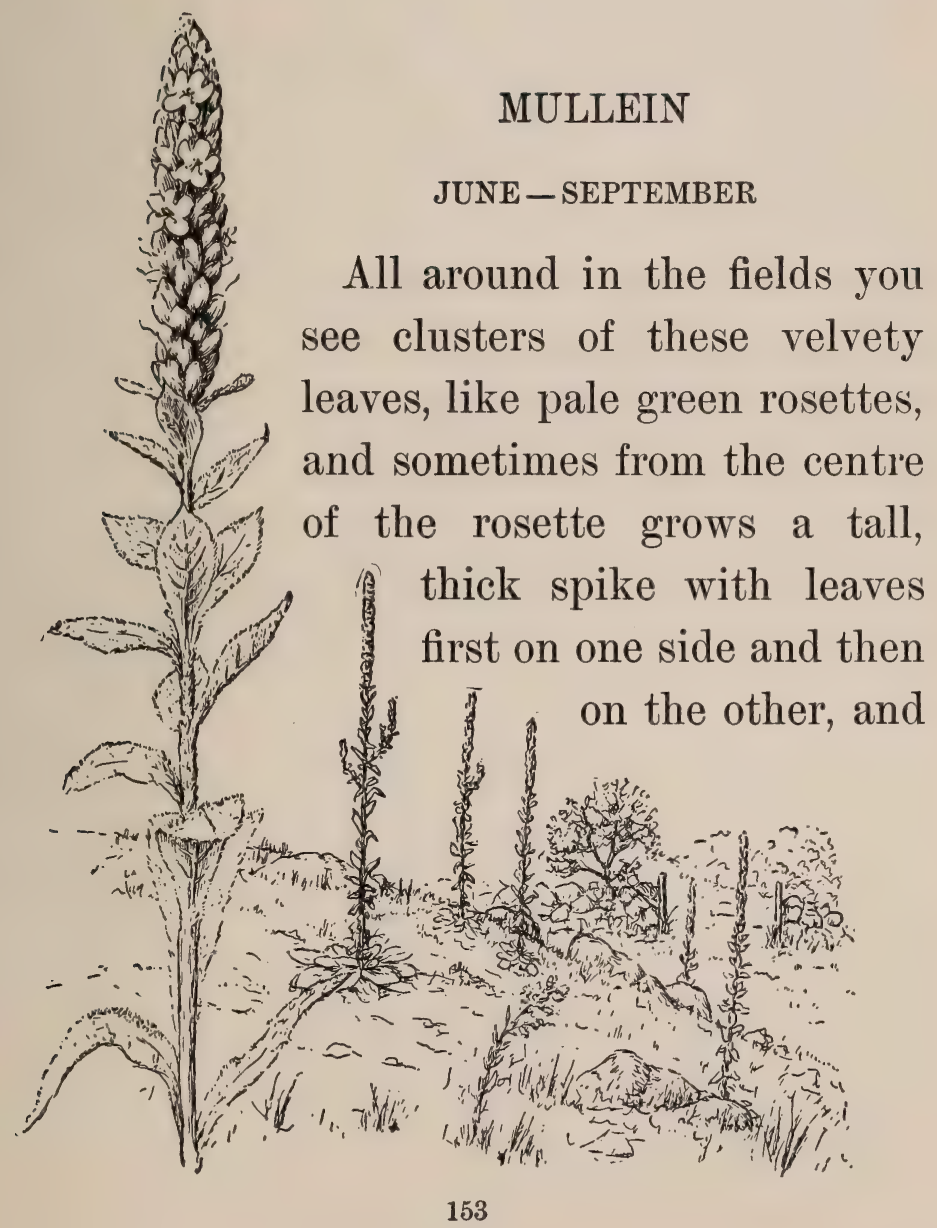


many pale yellow flowers clustered at the top. Some one has told you that these flowers only bloom when the Mullein plant is two years old; the younger plants have only the green velvet rosettes. How soft the leaves are! You pick them, two or three at a time, and rub them against your cheek. Such a pretty shade of green they are, too, you wish you could make a whole dress of them for your dolly. Once you saw a wonderful moth almost the same color, and you thought him very beautiful.

For some reason you like the leaves of Mullein far better than the flowers. You cannot think of any other plant with leaves of such soft velvet. Mullein belongs to the same family as your dear Butter-and-Eggs, though you would hardly believe it, would you? They certainly do 
not look much alike. In flower families, as in families of children, all the cousins do not look alike, though there is usually a resemblance in one way or another.

The Mullein's yellow candles burn Over the heads of the dry sweet fern;

All summer long the Mullein weaves His soft and thick and woolly leaves.

- Margaret Deland. 


\section{BUTTER-AND-EGGS}

Figwort Family

Linaria Linaria

Linaria vulgaris

JUNE - OCTOBER

Fields and waste places. The rootstocks are short. Stems slender, very erect, leafy, smooth. The leaves are long and narrow, without petioles, pointed at both ends, alternate. Flowers are in dense racemes, light yellow and orange. The calyx is five-parted. Corolla is irregular, spurred at base, two-lipped, the upper one erect, twolobed, the lower spreading, three-lobed. The base forms a palate often nearly closing the throat. There are four stamens in two pairs, filaments slender. The pistil has a slender style. The seeds are numerous. 


\title{
BUTTER-AND-EGGS
}

\author{
Toad-Flax \\ JUNE - OCTOBER
}

"Butter-and-Eggs, Butterand-Eggs," you sing as you run along the road and see whole masses of these bright flowers nodding at you, almost begging to be picked. You know that it will do no harm if you gather great handfuls of them, for they are everywhere; - stretching along the road as far as you can see, peeping at you over the stone walls, and filling the meadows beyond with their brightness.

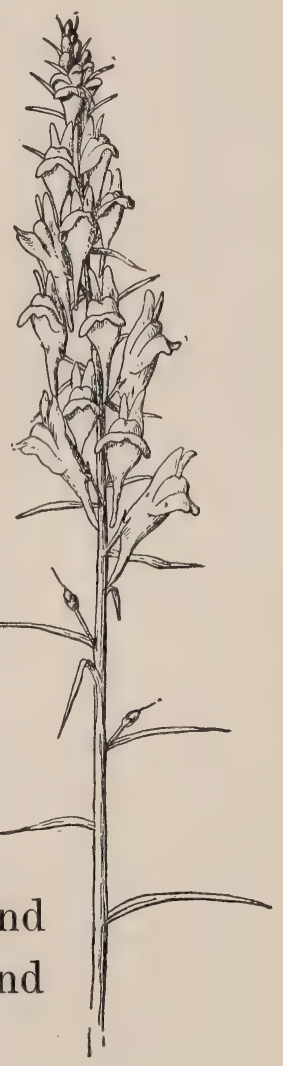


How you love the yellow and orange blossoms. You feel that the bees and the butterflies must love them; too, and you watch a big bee while he goes from flower to flower, gathering honey from the long spur.

You pinch the flowers to make them open their mouths, and you play they are funny dragons. Father tells you that sometimes these flowers are called Snapdragon and that they have another name, Toad-flax, besides the long, hard name that your little tongue cannot say. When Father tells you this, you play that all the flowers are little toads, and you make them open their mouths again. But you like your own name for them best, because the flowers are just the color of butter and eggs. You count all the blossoms in one cluster, and notice that the baby ones are 


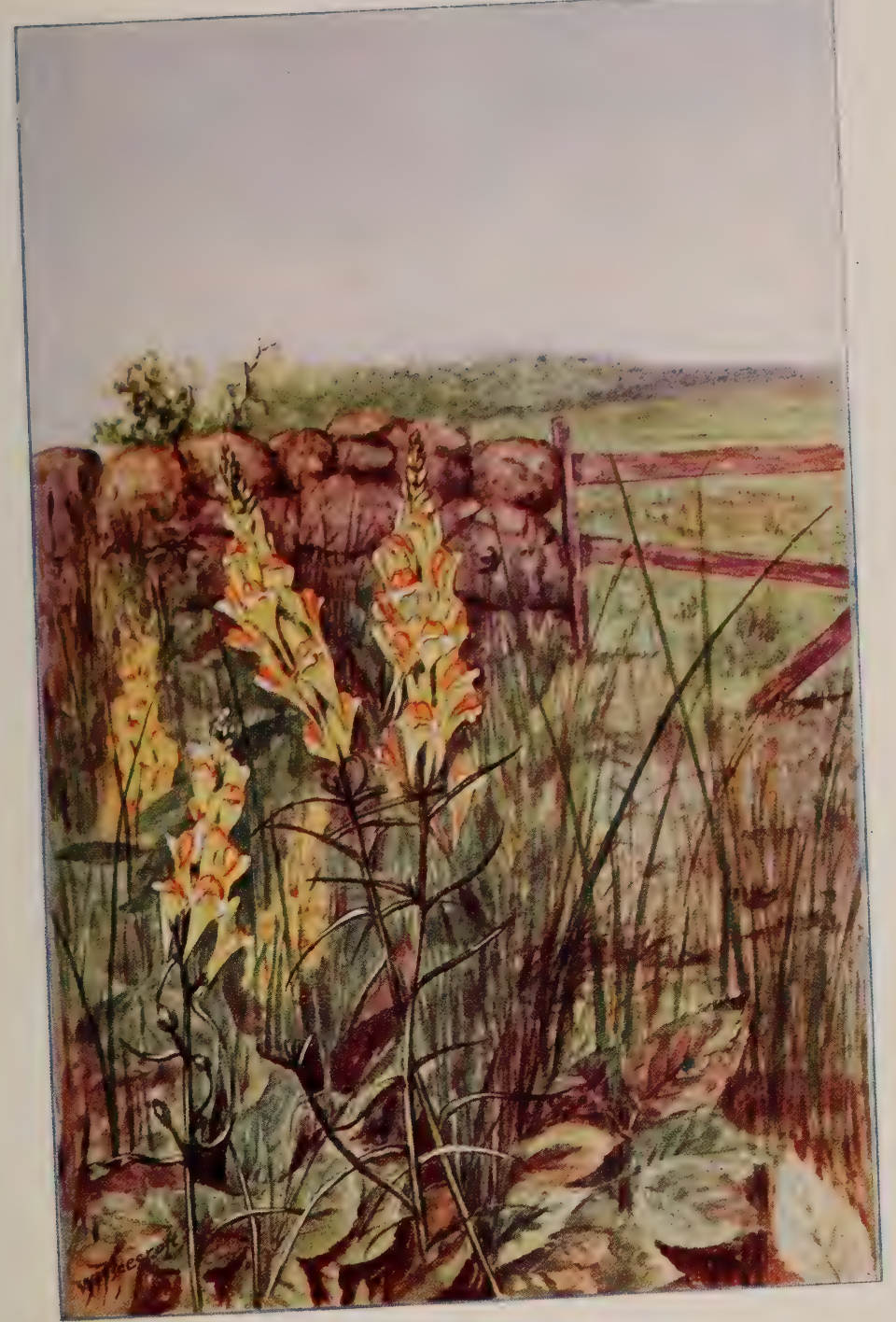

$$
\text { BUTTER AND EGGS }
$$



at the top, and you feel sure that the big ones are below to keep the babies from falling.

Toad-flax belongs to a big flower family named Figwort. You often see its cousins; Mullein and Foxglove, and in Grandmother's garden there is such a big bed of Snapdragons, red, yellow, and all colors. These are cousins, too. Once you tried to have a bed of Snapdragon in your little garden, and you planted seeds, oh, so carefully, thinking your garden would be even prettier than Grandmother's. Alas! the gardener came and raked over your garden, not knowing you had planted anything. Your grief was deep, but after awhile some of the Snapdragons really did come up, scattered all over the garden in such a funny way that they made you laugh. 


\section{PICKEREL-WEED}

Pickerel-Weed Family

Pontederia cordata

$$
\text { JUNE - OCTOBER }
$$

Is shallow ponds and streams. The stem is from one to two feet high. Leaves are heartshaped, or lance-arrow shaped. The flowers grow in a spike at end of the stem, and are purplish blue with greenish yellow spot on upper lobe. Each flower remains open only one day. Perianth is of six divisions irregularly united below in a tube. Three of the divisions form an upper lip, three-lobed; the other divisions are more spreading. The six-ribbed base thickens, turns green, and encloses the fruit. There are six stamens, the three lower ones with filaments curving inwards, the three upper ones shorter. One pistil, and fruit one-celled, one-seeded. 


\section{PICKEREL-WEED}

JUNE-OCTOBER

The first time erel-Weed you

were driving

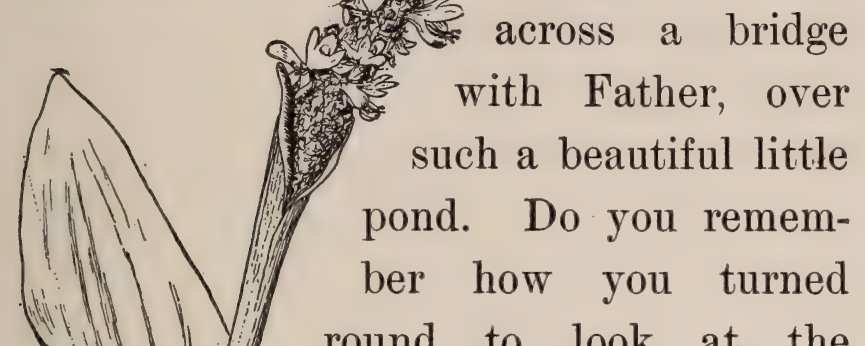
round to look at the water, and suddenly discovered a mass of blue flowers close by the shore? "Oh, oh - Father," you cried, "please let me get out and see that water garden." As you ran back across the bridge and 
came closer to the edge of the pond, you saw that the flowers grew in spikes from out a sheath-like leaf, and stood up very straight and tall, like soldiers with high blue caps. Such hosts of dragon flies were darting about, their wings seeming to catch a glint of blue from the flowers! You went a little closer, almost to the water's edge - and then how disappointed you were to see that the flowers were not nearly so beautiful as they looked a little distance away. The blue caps were ragged and dingy-looking, for many of the flowers had bloomed and withered but were still on the stalk. Father told you that each flower lasted only one day, but every day new ones opened, so that there were always a great many in bloom, quite enough to make the whole edge of ponds and rivers look blue. 
You were very well satisfied to look at Pickerel-Weed from the bridge after this, where you could see whole masses of the blue, instead of many brown, withered flowers here and there among the fresh ones.

You wonder why these blue flowers should be called Pickerel-Weed, as you don't see any resemblance to the pickerel that is in your "fish book" as you call it. Then some one tells you that it is because the pickerel and Pickerel-Weed both like the same shallow ponds, so you make up your mind to look for fish the next time you see these blue flowers, and decide to take some bent pins along in your pocket to catch a big pickerel for Mother. 


\section{ORANGE HAWKWEED}

Chicory Family

Hieracium aurantiacum

Composite Family (Gray)

JUNE - SEPTEMBER

Found in fields, woods, and along roadsides. Stem leafless, or with one or two small leaves without petioles; hairy, slender. Leaves at base of stem hairy, tufted, spatulate, or oblong, narrowed at base, entire, or sometimes slightly toothed. The flower heads have short peduncles, or stalks, and are in corymbs. The color is orange or red. The involucre has long and narrow lance-shaped bracts, overlapping in two or three rows, hairy. Receptacle of head flat. Corolla of united petals with a long tube, and strap-shaped ray. Akenes oblong. Pappus, or down, a single row of slender brownish bristles. 


\title{
ORANGE HAWKWEED
}

\author{
JUNE - SEPTEMBER
}

You thought at first that these bright orange-red flowers were poppies, as you drove by on the country road, but when Father stopped the carriage and you ran back to see them, you found they were something quite different. What hosts of them there were, and what a splendor of color! you gathered a handful and

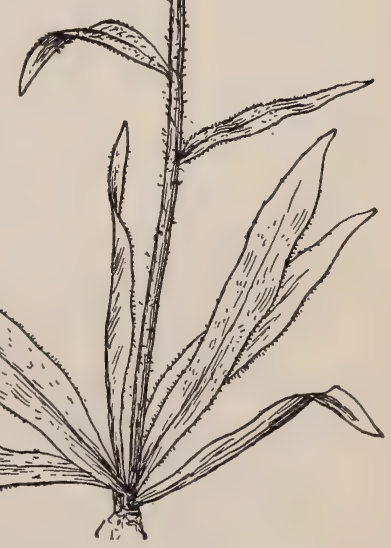


hurried back to the carriage, breathless. What were these new treasures? You had never seen anything like them before.

The bright flower heads were in clusters at the top of a stem covered with long, fine, black hairs. How curious it was! You learned that the name was European or Orange Hawkweed, and also that it was a cousin of Dandelion and Chicory; then it was even more interesting than before. The flower heads were made up of strap-shaped flowers, closely clustered, so that they made one blaze of color. The leaves were close to the ground, and they were hairy like the long, straight stem.

Many times since that day you have looked for Orange Hawkweed, but have not happened to see any except in that one place. The gorgeous flame color de- 


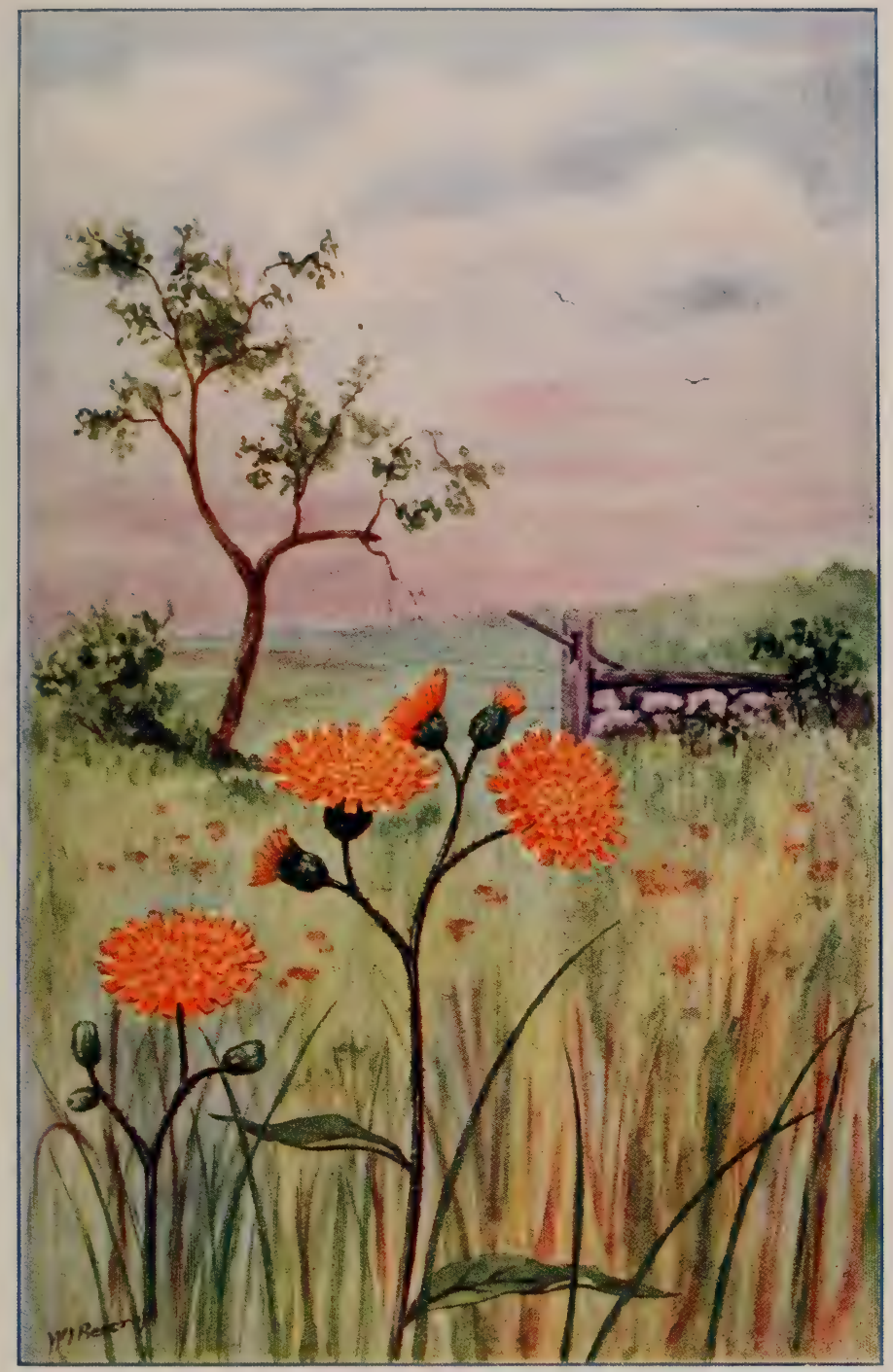

ORANGE HAWKWEED 

lights your eye, and you hope every year to welcome these friends which are so closely related to other good friends of yours. The Composite Family is so large, and there are so many branches of it, that you are continually finding new members, or greeting old friends wherever you go.

Orange Hawkweed has several other names; it is sometimes called Devil's Paint-brush, and in England is called "Grimm the Collier." It has not been many years in this country, but in some places the farmers are already wishing it had not come at all, as it is getting troublesome in their fields. Strange that so many of your favorites are disliked by the farmers, isn't it? but you see they are not thinking of the beauty of the flowers, but of the way the plants spread and threaten to drive out their crops. 


\section{WHITE SWEET CLOVER}

Pulse or Pea family

Melilotus alba

\section{JUNE - NOVEMBER}

Runs wild in waste or cultivated ground. Has been cultivated for fodder. The stems are branching, tall, from three to six feet high. Leaves are of three leaflets, notched at the ends, the top one jointed with the common petiole above the side leaflets. Sweet-scented, especially after drying. The flowers are small, white, growing in slender racemes. The calyx is very small, the corolla of five petals, the standard, wings, and keel short. The pod is small, but larger than the calyx; is globular, wrinkled, and contains one or two seeds. 


\section{WHITE SWEET CLOVER}

\section{JUNE - NOVEMBER}

\section{The field all crossed}

and criss-crossed by paths - some worn smooth and wide by the tread of many feet, others only faint suggestions, to your mind and imagination the trails of Indians and wild beasts - was your special playground. Here how many Indian battles were fought, how many lions and tigers brought
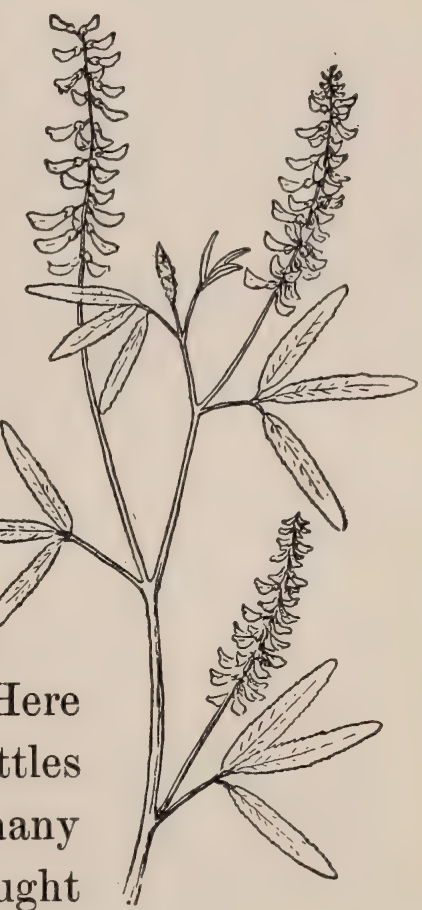
home in triumph after a long chase what royal games were played! Here was the maze, in the centre of which lived the dreadful "Minotaur" whose hoarse, fierce growls and howls could be heard from afar. Even the brave "Theseus" was a little timid about venturing into his domain, which was guarded by Burdock sentinels, and hedged round by Sweet Clover. You sometimes regretted that this monster should be so surrounded by sweetness; but what a perfect little room the bushes made! It required courage to pass by the swarms of bees that always seemed to be hovering about, to say nothing of the fierce "Minotaur."

You have a fondness for Sweet Clover, and often take home great bunches of it to dry and put in your drawer, for the fragrance is delightful, strongly remind- 
ing you of the sweet grass used by the Indians in making baskets. Some one has told you that these dried flowers and leaves will keep away moths; but you have never been able to persuade Mother to use them instead of camphor.

Sometimes you find yellow Sweet Clover, which grows on smaller bushes, but looks very much like the white. It is not as dear to you as your friend Sweet Clover of the "Jungle," and has not so many pleasant associations. Sweet Clover is a relative of the fragrant honey clover of the meadows, and of many of your friends belonging to the Pulse or Pea Family. You remember that Wild Lupine belongs to this family, and your Wistaria that droops its graceful flower masses over the little balcony just outside your window. 


\section{YARROW}

Thistle Family

Achillea Millefolium

Composite Family (Gray)

\section{JUNE - NOVEMBER}

Frelds, hills, and along roadsides. Comes up year after year from horizontal rootstocks. The stems are simple or branched like corymbs, one to two feet high. The leaves from the base are petioled; those on the stem without petioles, cut into fine, narrow divisions, slightly hairy or woolly. The flower heads are numerous in compound corymbs at the top of the stem, white or pink. The involucre with oblong bracts. The receptacle is nearly flat, or convex, chaffy. The ray flowers have pistils, but no stamens; the disk flowers are perfect; the corollas are yellow, five-lobed. Akenes are oblong or obovate. There is no pappus (or thistle-down). 


\section{YARROW}

\section{JUNE - NOVEMBER}

Whenever you see Yarrow it reminds you of the little lane at Grandmother's, down which you have so often gone to bring home the cows. What a dear lane it is, - the prettiest spot on the whole farm, you think. Here is where one finds the first wild roses, hosts of them, just begging to be picked, it seems ; and

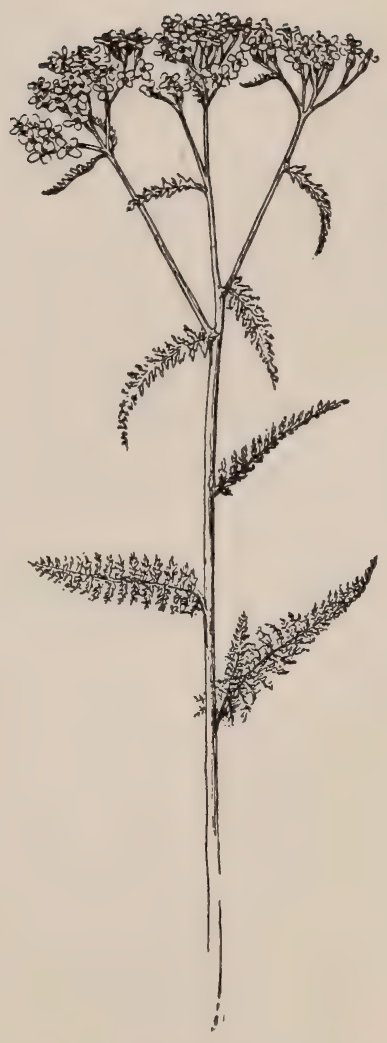


all along the way are raspberry bushes, in the season just loaded down with luscious berries. Along the old gray fence barberries droop with their burden of coral, and if one has very sharp eyes it is possible to pick a basketful of wild strawberries in no time. All summer long Yarrow flourishes here as you have never found it elsewhere. What a homely, comfortable-looking herb it is, the flower clusters made up of ever so many little white flowers like Daisies, with white ray flowers and yellow centres.

Once you found some pink Yarrow, and it was a pleasure to recognize an old friend in a new dress. You have looked many times along the lane, hoping to find more pink, and even some blue Yarrow, for you thought perhaps it would blossom in all colors. However, you have never 
found any more pink blossoms, and have now given up hopes of finding blue, as you realize that wild flowers usually stick to one color or variations of it. The leaves of Yarrow are pretty, very fernlike and lacy, they are so divided and subdivided. Yarrow is another cousin of Daisy and Black-eyed Susan, and numbers of your friends in the Composite Family. Just think what a big bouquet it would make if you should gather one of each member of this family. You cannot go into the fields or along the roads, or, indeed, anywhere in the country, without seeing one or more of the cousins of Yarrow, some nearly related, others more distant, but still belonging to the same big family. 


\section{YARROW - MILFOIL}

Everywhere the Yarrow grows!

Here and there the thistle blows,

Here and there the barberries,

By the brook the plumy fern;

We know where the lily is,

Where the dear wild roses burn;

But the Yarrow everywhere

Wanders on the common air.

No one need to search for thee;

Even now thy leaf I see

Peeping o'er my opened book,

Throwing so fair a shadow down,

So perfect, that I can but look,

And, looking, find new wonder crown

The bliss of beauty which before

Taught my spirit to adore. 
In thy bitter odors blent

Health we find, not discontent;

In thy name a tender grief

For that love once drowned in Yarrow,

Stream that never gave relief

To the faithful, "winsome marrow."

Bitter Yarrow! Flowing Yarrow!

Still lament thy winsome marrow!

Emblem of our equal land,

Where men and women helpful stand,

And love and labor, high and low.

Type of the low! Thou lovely plant!

Teach the proud-hearted how to know

The sacred worth of nature's grant,

The strength of bitterness, and the sweet

Humility of beauty's feet.

- Annie Fields. 


\section{WHITE ALDER}

White Alder Family

Clethra alnifolia

Heath Family (Gray)

\section{JULY - AUGUS'T}

Swamps and wet woods, sometimes in dry soil. Shrubs three to ten feet high. Leaves green on both sides, obovate, narrowed at base, sharply toothed, with petioles, falling in the autumn. Flowers white, fragrant, in long, narrow racemes at ends of stems. Calyx with five lobes, remaining after the fruit is ripened. Corolla of five petals slightly united at base, falling before the fruit ripens. There are ten stamens with slender filaments, and anthers shaped like arrowheads. The pistil has a slender style and three stigmas. 


\section{WHITE ALDER}

Sweet Pepper-Bush

\section{JULY - AUGUST}

More than a mile away across the downs you can hear the sea dashing itself furiously against the rocks, trying to make a passageway through to the peaceful harbor on the other side of the point. It is not always so wild; many times you have walked over the downs by your favorite path, and found the ocean in a gentle mood, playfully toying with
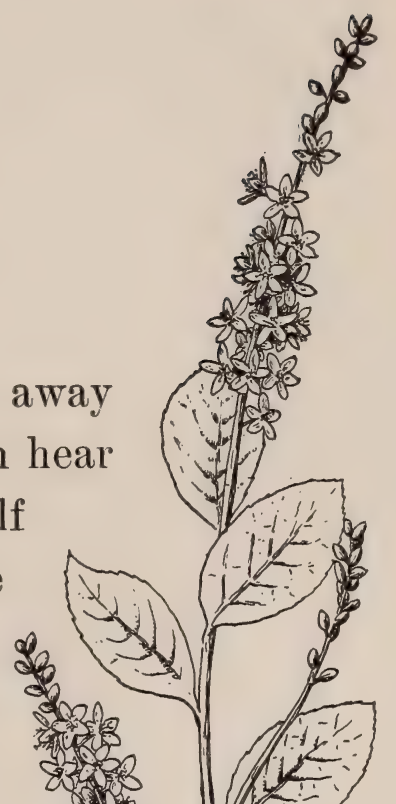
bits of seaweed as your kitten plays with a soft ball of wool.

How spicy and fragrant the air is with the delicious, unspeakable combination of salt breeze and the perfume of White Alder, or Clethra, as you like to call it. You draw deep breaths, and wish you were twice as big, so that you could inhale more of this fragrant air. Then what an inspiration it is to run over the little hills and down into the hollows between - then a scramble up on to one of the high rocks that were kindly left here by Mother Nature, that one might take a survey of the ocean and harbor, and the dear, wide-spreading downs. The Clethra is ever present; great masses of the bushes border the innumerable little paths that wind in and out, now losing themselves in an impassable bog,- im- 
passable, that is, except to the cows that one has a continual dread of meeting among the bushes, where their big heads and horns would indeed be formidable. The paths have the most charming way of seeming to be direct routes to the ocean, - how plainly we can hear the roaring, and the sea is now really close at hand, - when suddenly, with a little twist, the path ends, leaving us to find our way out as best we may from Clethra and Bayberry bushes. We stop to gather a few sprays of the flowers to take to Mother, and a handful of the Bayberry leaves that have such an agreeable smell when crushed, - and then we try another path. 


\section{KNOTWEED}

Buckwheat Family

Polygonum Pennsylvanicum

\section{JULY - SEPTEMBER}

Found in moist soil. The stems are from one to three feet high, branching. Leaves are lanceolate, alternate, with stipules in the form of thin and dry sheaths. The flowers grow in oblong, thick, erect spikes, and are rose color. There is no corolla. There are eight stamens, a little protruding; and the one pistil has a two-cleft style. The fruit is an akene, a kind of dry, one-seeded fruit, which looks like a seed, though the true seed is inside the outer covering. 


\section{KNOTWEED}

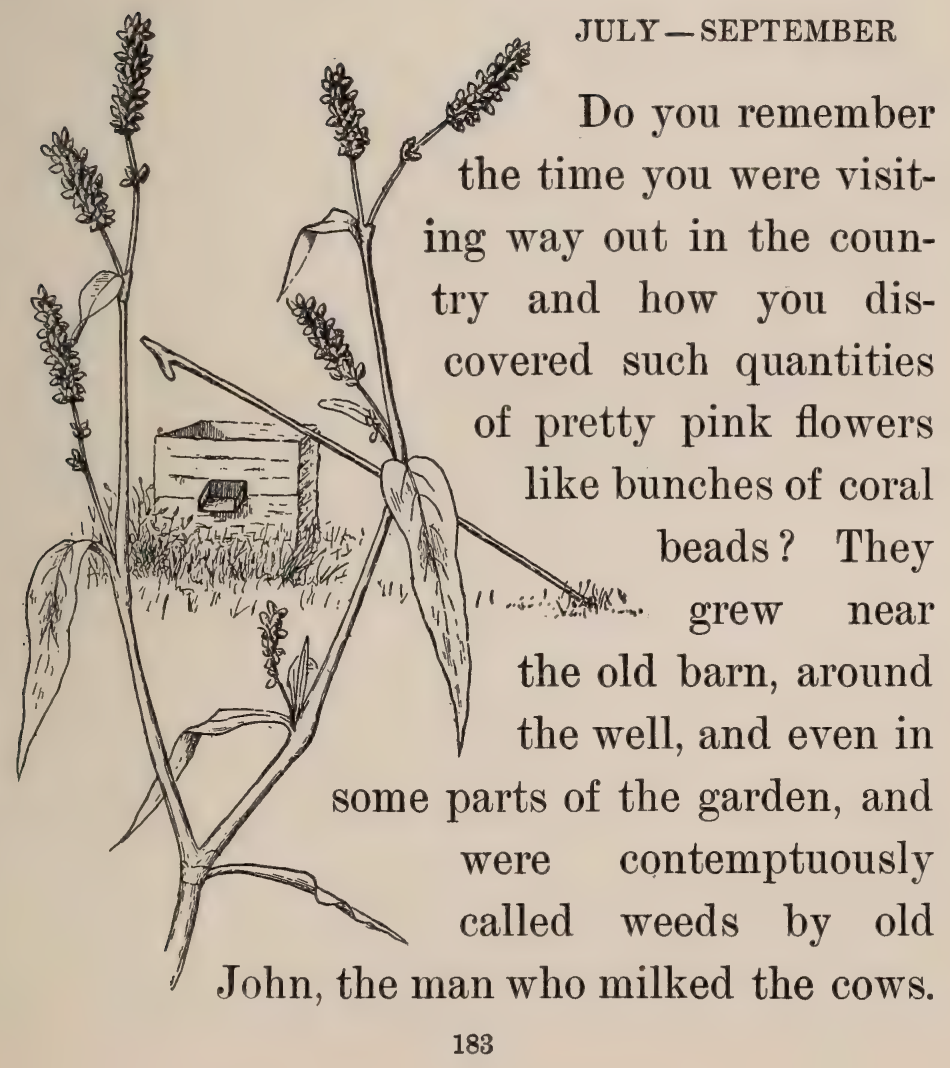


You were very fond of going about with John. He knew ever so many interesting stories about the birds and bees, and made cold shivers run down your back when he told you snake stories. One day you discovered the Pink Knotweed, and liked it so much that you gathered a handful, taking it to old John to ask him if he knew the name of these growing coral beads. How disgusted you were when he called them weeds! "Huh," he said, "Them's nothing but Knotweed." You thought the little flowers ought to have a prettier name, and for a few minutes your faith in John was shaken, but then you thought that, after all, the little flowers did look like pink knots, and it was not such a bad name for them.

They grow in thick, spiked clusters, and make many a neglected corner bright 
in old gardens, or about the dooryard of old houses. Sometimes you find another Knotweed growing beside ponds or little streams, sometimes right in the water. One of the Knotweed cousins grows in the sand near the sea - you have often seen it, haven't you? Knotweed belongs to the Buckwheat Family, and is related to the Buckwheat grown by farmers, to be ground into flour. You have eaten cakes made of Buckwheat, haven't you? 


\section{WILD MINT}

Mint Family

Mentha Canadensis

JULY - OCTOBER

Is damp or wet places. Spread by running rootstocks. The stems are square. Leaves are aromatic, ovate, or pointed, on short petioles, opposite, with toothed edges or margins. The flowers are blue, in whorls in axils of some of the middle pairs of leaves. The calyx is equally five-toothed. Corolla has a four-cleft border, upper lobe a little broader, sometimes notched at the end. There are four stamens, nearly equal and similar. The one pistil has a two-lobed stigma. The fruit is four-parted, like four little nuts or akenes, each containing one seed. 


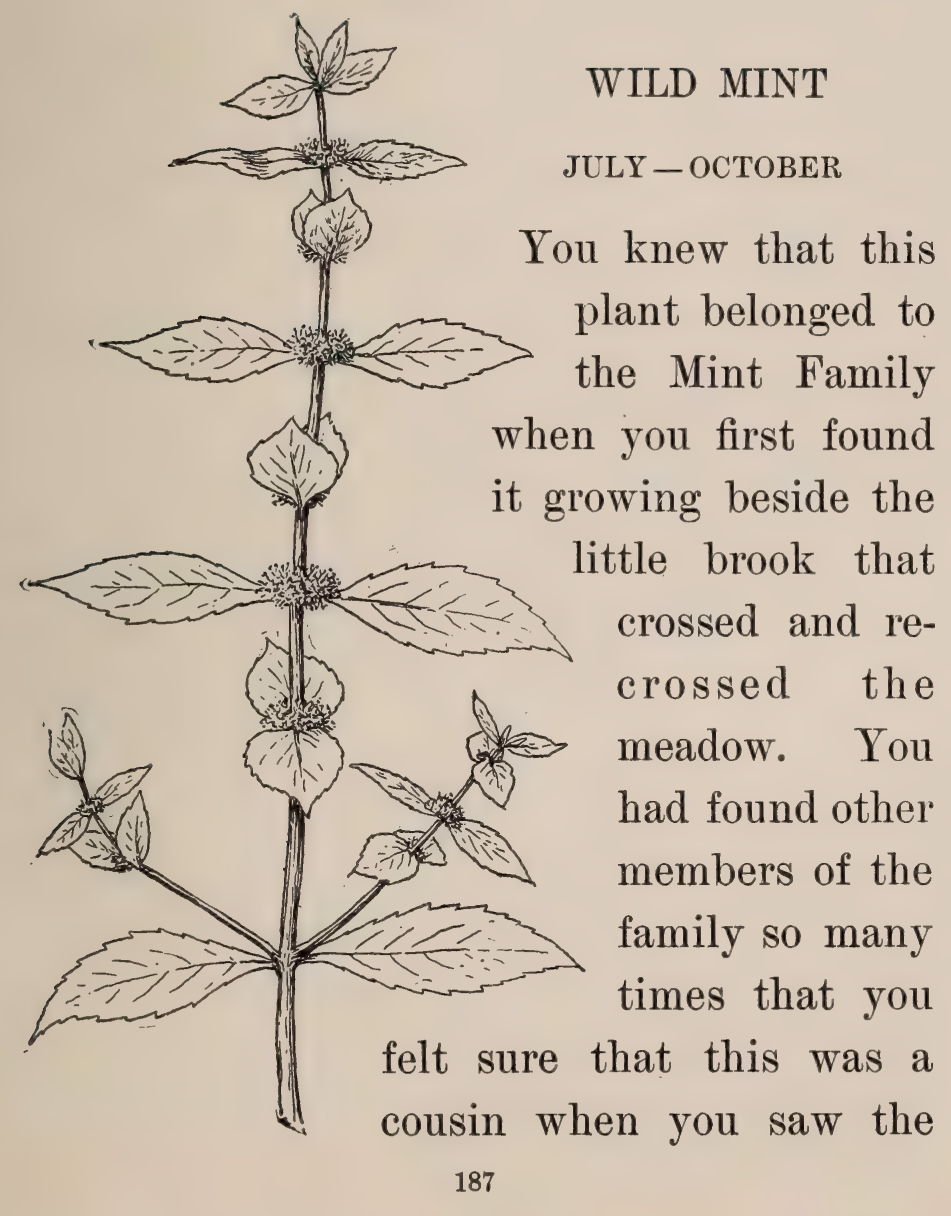


square stem and opposite leaves with flowers in whorls between. It had a pleasant minty fragrance, too, — so you asked Father what kind of Mint this was. He was pleased that you had recognized the plant, and told you that it was Wild Mint. Along this brook you found several other plants of the same kind, and also a quantity of Spearmint, the leaves of which are so aromatic.

You had such a delightful walk that day, - you had taken the electric car way out to a little country town miles and miles from your home, then walked out still farther on a very pretty road. Up and down it went over little hills and valleys, then across bridges, where you stopped and looked down at the brooks peacefully flowing along over shining pebbles, the water quite deep, but 
clear as crystal; then on to where the road was shaded by willows, inviting one to rest and look about, for here on either side the wide meadows stretched, beautiful with the masses of Goldenrod, Joe Pye, and little clumps of shrubs and baby trees. Here the brook crossed, as one could see by the luxuriant growth of shrubs and plants; over there in the shadow of the trees gleamed the splendid Cardinal Flower, and as far as the eye could see was spread out this wonderful garden of Mother Nature. You begged Father to let you run along by the side of the brook, and it was here that you found the Wild Mint, as well as a host of other treasures. You hated to leave this charming spot, but this day of days had to come to an end at last, though you have never forgotten the joy of it. 


\section{DODDER}

Dodder FAMiLy

Cuscuta Gronovii

Convolvulus Family (Gray)

\section{JULY - AUGUST}

Grows on herbs and low shrubs. Stems are yellow or orange, slender, high-climbing, fastened to plant, on which they are parasitic, by numbers of tiny suckers. Leaves reduced to scales. Flowers numerous, in dense cymes. Calyx lobes ovate, shorter than corolla tube. Corolla bellshaped, lobes rounded, spreading, nearly as long as the tube. The stamens are alternate with the lobes of the corolla, filaments short and slender. The styles are slender, stigmas with tops like pin-heads. The capsule, or seed pod, is short, pointed, somewhat round. 


\section{DODDER}

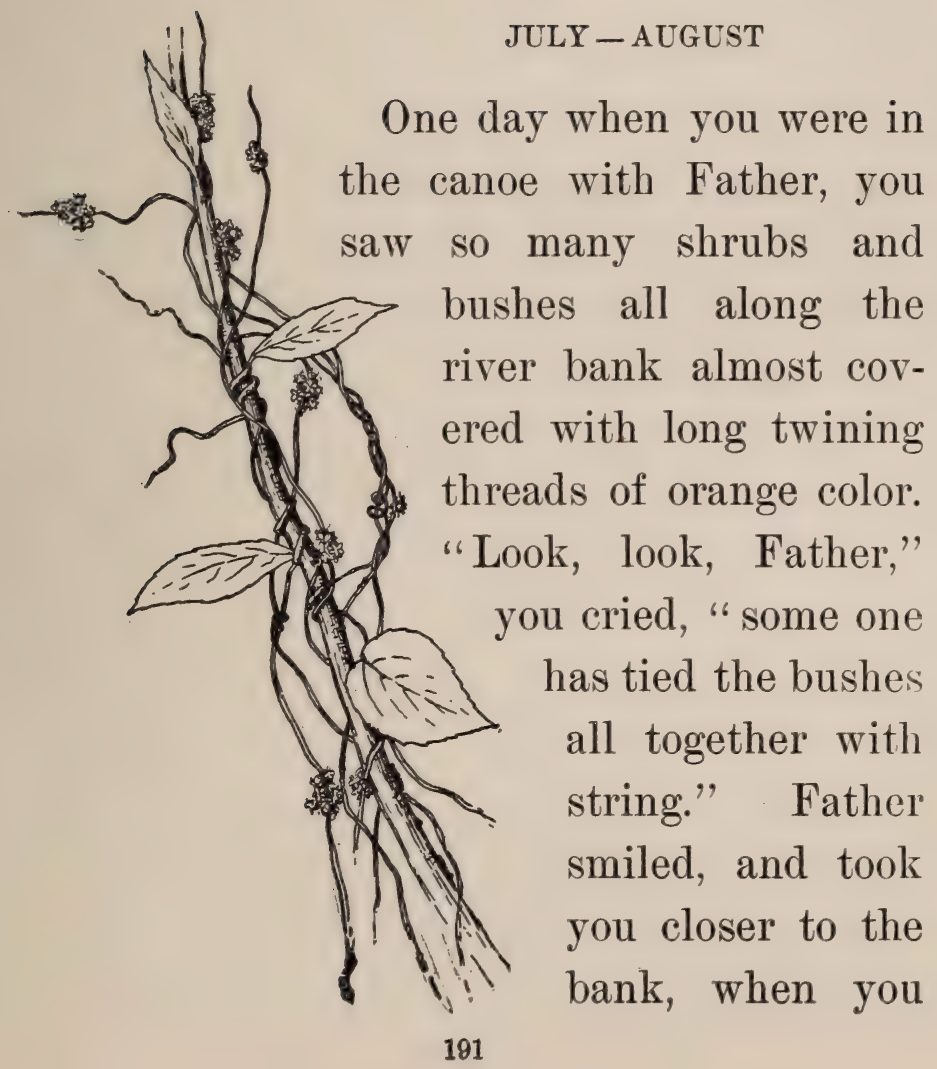


saw that the threads were growing plants, yet they did not seem to belong to the bushes they were on. You knew that Button-bush did not have orange stems anyway, and yet many of these bushes were twined round and round by the threads. In the sun they looked almost like wires of copper or bright gold. Here and there were bunches of small white flowers, not very interesting, or as pretty as the stems.

You were surprised and disgusted to hear that these plants lived by taking sap from the bushes and shrubs round which they twined. Indeed, they clung so closely that it was impossible to get a piece of the Dodder without taking some of the bush as well. You thought they were very mean plants to steal sap from bushes, and for a while you didn't 
even want to look at the pretty orange stems.

It was a surprise to you to hear that Dodder belongs to the same family as your Morning Glories, which are rather better behaved cousins, though their tendrils cling, too, to everything within reach. 


\section{PARTRIDGE PEA}

Senna Family

Cassia Chamcecrista

Pulse Family (Gray)

JULY - SEPTEMBER

Is dry soil. Erect, or spreading, widely branched. Leaves of from ten to twenty pairs of leaflets, linear oblong, or the upper ones lance-shaped, sensitive. Flowers, from two to four together in the axils, yellow, some of the petals often purple-spotted, pedicels slender. The teeth of the calyx are nearly equal, generally longer than the tube. The corolla is nearly regular, with five spreading petals. The seeds are numerous. 
PARTRIDGE PEA

JULY - SEPTEMBER

\section{s.}

by the railroad track, almost at the edge of the high, gravelly bank, and then winds delightfully in and out among the trees, is where you most often find the Partridge Pea. You are fond of the bright yellow flowers and the pretty, delicate leaves that have a way of folding like a fan if one handles them too roughly.

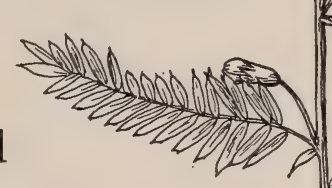


You never have been able to see any resemblance in this flower to any other Pea blossom, but you notice that the pods are long, containing many seeds, so you are satisfied that Partridge Pea is a very good name for the plant. How often you have seen it along this dear path that has so many surprises. When you follow it you pass the most fairylike little ravines, down through which you get glimpses of the water, - and suddenly are at the very edge of a high bank that slopes down to the prettiest little pond imaginable. What a temptation it is to leave the path here and scramble down through underbrush and between trees - down, down to the water's edge - then what a delight to walk along, skirting the pond! Here, in the spring, one passes through arches of Wild Azalea, great masses of 
these deliciously fragrant flowers. Isn't this a joy to be remembered all the year? Then going on, you come to a big spreading tree with branches invitingly near the ground, promising a restingplace where you can recover your breath, for it must be confessed that in some places the tiny path is hard to follow, being overgrown by shrubs, and bushes, and briers, that have a way of clutching at one who passes.

Black Birch trees offer you refreshment by the way, and you nibble bits of the spicy bark while taking your rest. Up and down the path goes now, sometimes making you cling to branches and roots of trees for support, and again leading you to the dearest little beaches where fairies might enjoy the bathing, and you can imagine fleets of tiny boats sent out. 


\section{JEWEL WEED}

JEWEL-WEED FAMILY

Geranium Family (Gray)

Impatiens biflora

Impatiens fulva

JULY - OCTOBER

Found in moist grounds. Comes up from seed every year, branched, from two to five feet high. The leaves are thin, ovate, or with both ends evenly rounded, pale and glaucous beneath, coarsely toothed, petioles slender. Flowers horizontal, hanging from pedicels, orange-yellow, mottled with reddish brown. Calyx of three sepals, two side ones small, green, nerved, upper one petal-like, sac-shaped, spurred. Corolla of five petals, or three, with two of them two-cleft into lobes that are not alike. There are five stamens with short filaments more or less united. Pistil with a short style, or none, and five-toothed stigma. Fruit, a pod which bursts when touched, discharging the seeds. 


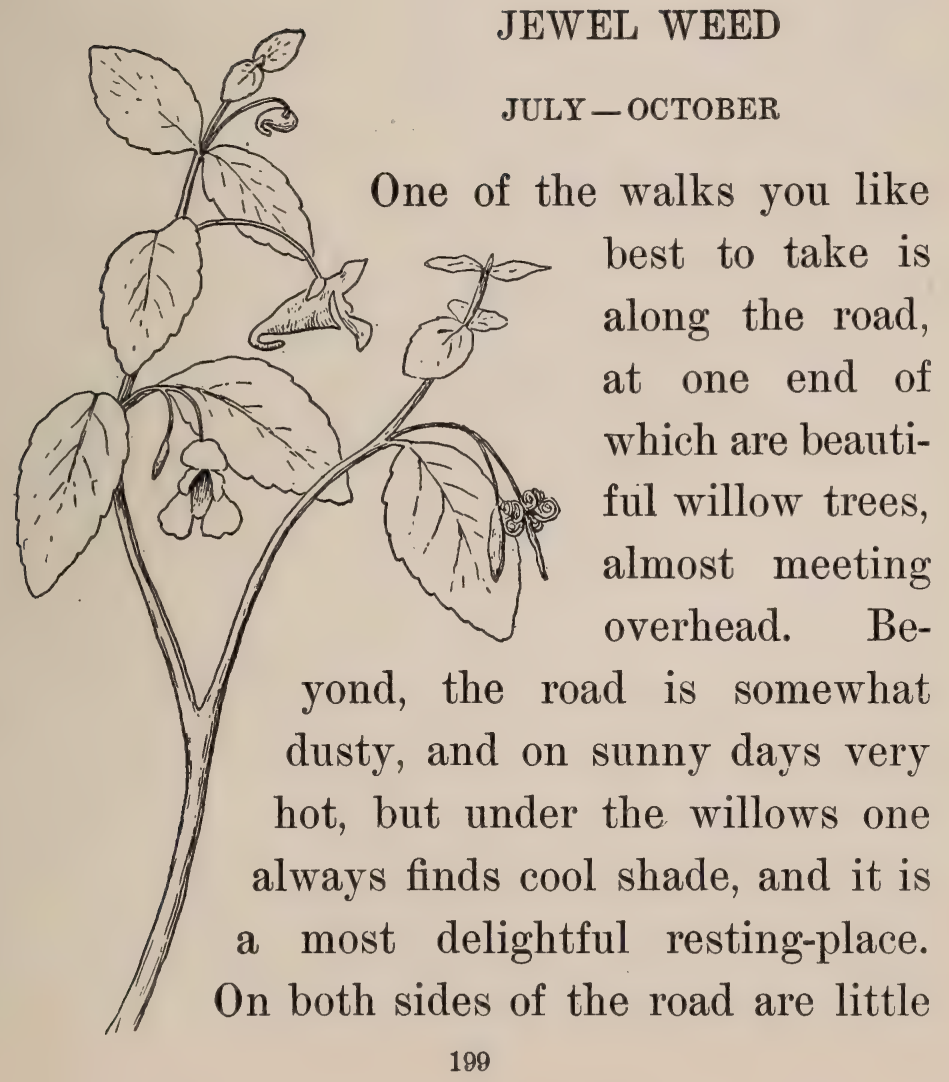


ditches, with tiny brooklets singing their way along so gently that one must stop and listen intently to hear them at all. Along here are bushes hung with the brilliant flowers of Jewel Weed, looking like the ear-drops of some fastidious Eastern princess, so jewel-like and splendid in color are they. Each one hangs from its stem lightly, so that a touch will set it in motion, just as the old-fashioned ear-drops belonging to Grandmother shake when you take them up by the wires.

Jewel Weed is not a new friend; you have known it a long time, and often have found it growing almost in the river when Father has taken you out in the canoe. You are never tired of the flowers; the color pleases your eye and you are always delighted to find them. Many times you have tried to paint a 
picture of Jewel Weed in your little book, but somehow the spots do not look right, though you are very particular to paint them brown on the yellow flower. Even when you count the spots, and make your flower exactly like those you have carried home from your walk, the brown spots have a disagreeable way of spreading, so that your painted flower looks like a mud pie, or a very much freckled yellow cat, or something equally unlike your idea of Jewel Weed. 


\section{JEWEL WEED}

Where the brooks stray through the meadow

By alders shaded deep,

There dwells a woodland goddess

Who seems a watch to keep

O'er the waters clear as crystal

(The mirror of the trees),

As she holds her tiny pictures

While swaying in the breeze.

To her guest in black and yellow,

The roving honey-bee,

She offers wild-wood nectar,

Saying, "Quaff ; it is for thee!"

Though she loves secluded places,

She is a shy coquette, 
Swinging tiny golden pictures

By stream or meadow wet.

She brooks not condescension

From mortal hand, you know,

For, touch her e'er so gently,

Impatiently she'll throw

Her tiny little jewels,

Concealed in pockets small

Of her dainty, graceful garment,

And o'er the ground they fall.

Her tiny magic jewels

May be a fairy's gift,

For scattered by the brookside

They soon small leaflets lift.

What mortal knows the secrets

Of Flora's children shy,

Concealed in field and meadow,

That with the flowers die?

- Ray Laurance. 


\section{HARDHACK}

Rose Family

Spircea tomentosa

JULY - SEPTEMBER

Common in low grounds; two to three feet high. The stem is downy or woolly, leafy. The leaves are ovate or oblong, with serrate or toothed edges; they are downy on the under side. The rose-color flowers are crowded into very dense clusters, called panicles, at the top of the stem. The calyx is open and short, usually five-cleft, and does not enclose the pod. The petals are equal and broad. There are from ten to twenty stamens; the pistils are downy. The fruit consists of little pods with several seeds in each. 


\title{
HARDHACK
}

\author{
Steeplebush
}

JULY - SEPTEMBER

A long, long meadow, so big that one end of it is "Boston" and the other "New York," you think of when you see Hardhack. All along the stone wall it grows, in among the masses of Goldenrod, its pink spires pointing up like rosy fingers to the blue sky. It is a very old and dear friend of yours,

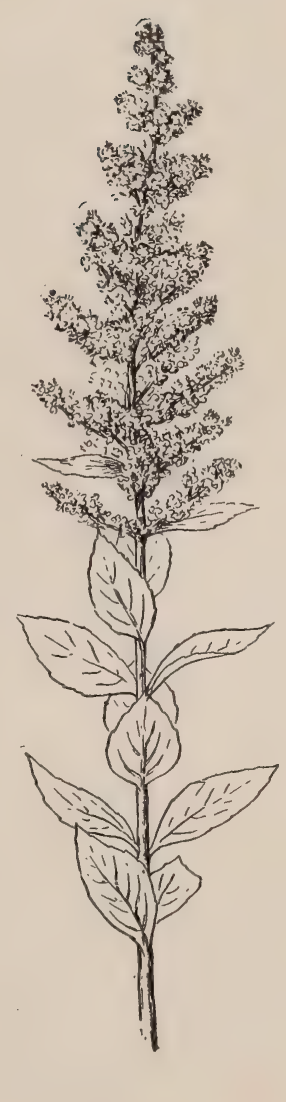


dearer still because it grows in your favorite meadow. In the centre of this meadow stands the big haystack, home of millions of crickets, it seems to you, for you cannot touch the hay without bringing out one hundred or more members of the cricket family to see what is happening. You are on the best of terms with them, and do not object to their being so near, as long as they do not crawl into your ears - to which you have a most serious objection. But the haystack is your joy - what a delightful place to hide things in, digging out handfuls of the hay, and stuffing it back carelessly after your treasures are hidden. What surprises you find sometimes! One day you accidentally discovered a long-lost bean bag which the hay storehouse had kept for you in good con- 


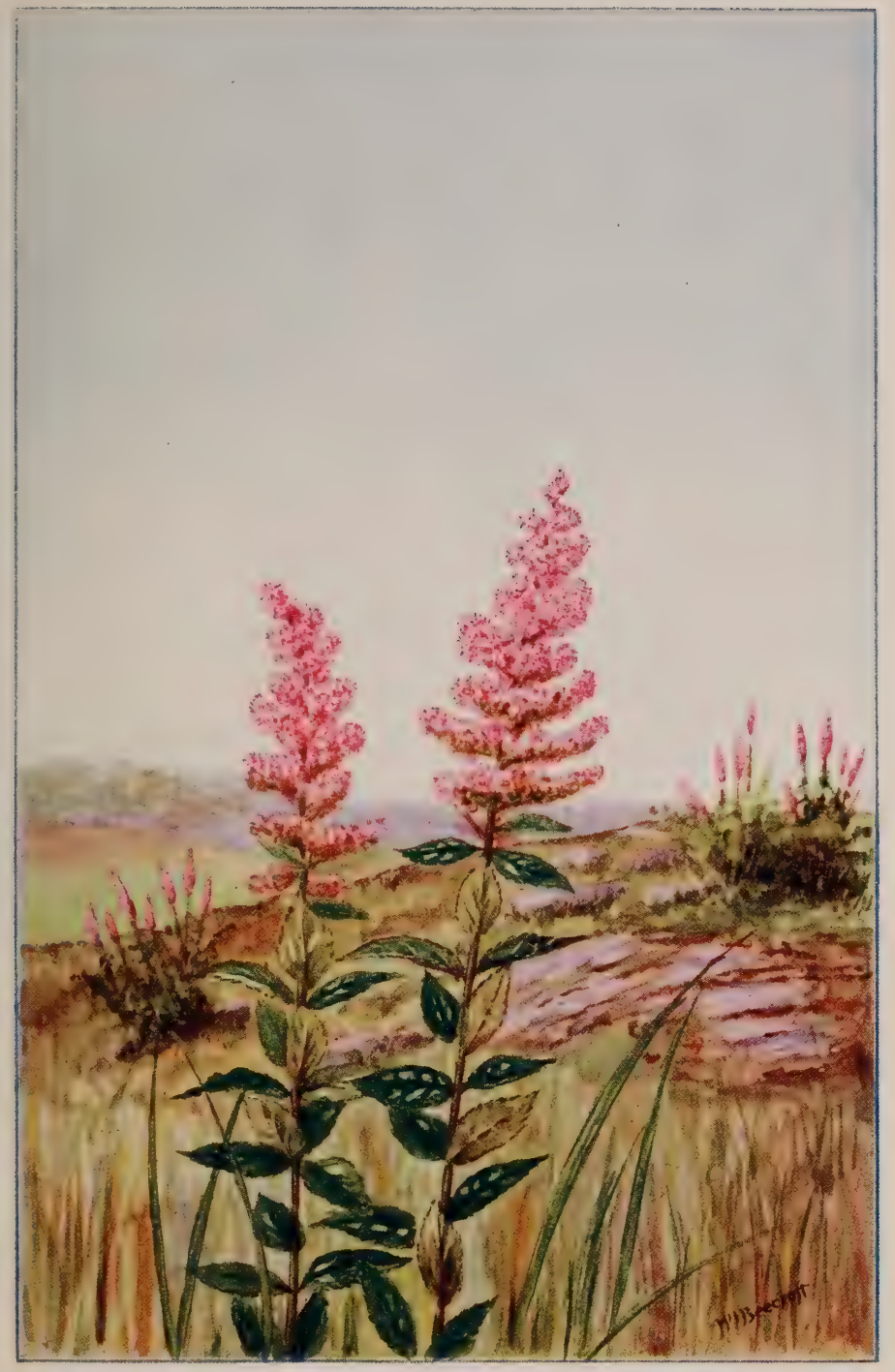

HARDHACK 

dition, quite unlike that of another bean bag that had, by some mistake, been left out in the rain.

Sometimes you dress the hay up with Goldenrod, and Asters, and Hardhack, then how gay it looks. The thickly clustered flowers of Steeplebush are most attractive to you; they are a very pretty shade of pink, and have such a feathery look. The leaves and stem are quite woolly, and you don't really like the feeling of them any more than that of a peach, which puts your teeth on edge.

How often the trains run from "New York" to "Boston," with "Haymarket" the most approved stopping place between. Many times the trains run off the track, but as yet no serious accident has occurred. 


\section{SPIRAA}

About half-buried boulders, overgrown

With cold gray lichens, and with patches round

Of yellow moss set in concentric rings

Upon rough surface of the weathered stone,

There stubborn Hardhack bold disputes the ground

With creeping vine, and to its refuge clings.

Not fed upon by browsing herd, Protection only claiming from the hoof, And having this from pasture-rock and wall ;

Retreat well noticed by sagacious bird, 
Whose nest has Hardhack leafage for its roof,

And close, rose-tinted racemes over all.

Among wild native bushes, creeping fast O'er our neglected fields and pastures bare,

How frequent is the blooming Hardhack met!

Its fragrance breathing of a happier past, When, in the mother-land, with thoughtful care,

A favored shrub, 'twas in the hedgerows set!

$$
\text { - Isaac Bassett Choate. }
$$




\section{TANSY}

Thistie Family

Tanacetum vulgare

Composite Family (Gray)

\section{JULY - SEPTEMBER}

Along roadsides, mostly escaped from gardens. The stem is stout, usually simple up to the flower clusters. Leaves are divided into many deeply and irregularly cut lobes. Flowerheads are numerous, strongly aromatic, yellow, in corymbs. The receptacle is flat. The marginal corollas have short, oblique, three-toothed borders. Disk flowers are perfect; anthers blunt and entire at base, with broad tips. Pappus a short crown. 


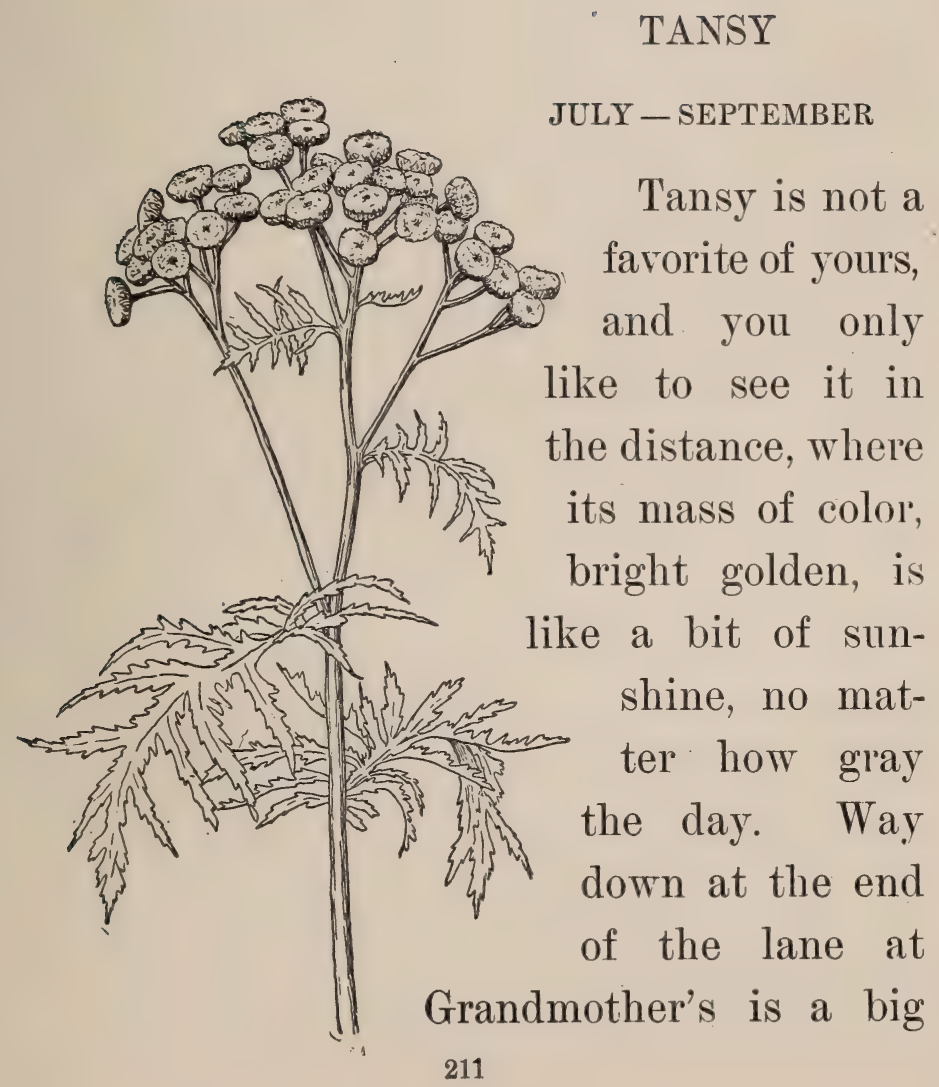


bed of Tansy, that many people have mistaken in the distance for Goldenrod, it is so brilliant.

What queer flower-heads this plant has, like Daisy centres without ray flowers, most uninteresting in your eyes, and it seems to you as though the flowers were only half finished. You do not like the smell of Tansy; it is very strong, and you think that the Tansy tea Grandmother has told you about must have been most disagreeable to take. She said that her Mother used to make this tea for medicine; and then how glad you are that you didn't live in those days, and that the medicine you sometimes have to take seems more like candy pills than anything as disagreeable and bitter as Tansy tea.

You would like to have seen the large bed of Tansy that Grandmother had when 
she was a little girl. Her Mother's garden must have been the most charming place in the world, with its wealth of Hollyhocks, Peonies, Snapdragon, Foxglove, and all the other beautiful flowers that grew there in such profusion. How you would like to have seen the old sundial, and the Box-bordered walks leading to delightful little summer-houses.

You love the smell of Box, and at an old, old house where you have been several times there is the most enchanting old garden imaginable, with, originally, numbers of Box-bordered paths. Now the Box has grown so high and so thick that in many places the paths are quite covered, and it is almost impossible for even you to squeeze through. But how delicious the air is with the spicy, indescribable fragrance of Box! 


\section{CHICORY}

Chicory Family

Cichorium Intybus

Composite Family (Gray)

JULY-OCTOBER

RoAdsides, fields, and waste places. Deep tap-root, from which the plants come up year after year. The stems are slightly bristly, stiff, with many branches. The leaves from base spread on the ground, narrow into long petioles. The upper leaves are much smaller. Flowerheads are numerous, one to four together in clusters without stalks, on nearly naked branches. They are bright blue, pinkish, or white. The receptacle is flat. The rays are five-toothed, and as if cut off at top. Anthers are shaped like arrow-heads at the base. Branches of the style are slender. Akenes are five-angled or fiveribbed. 


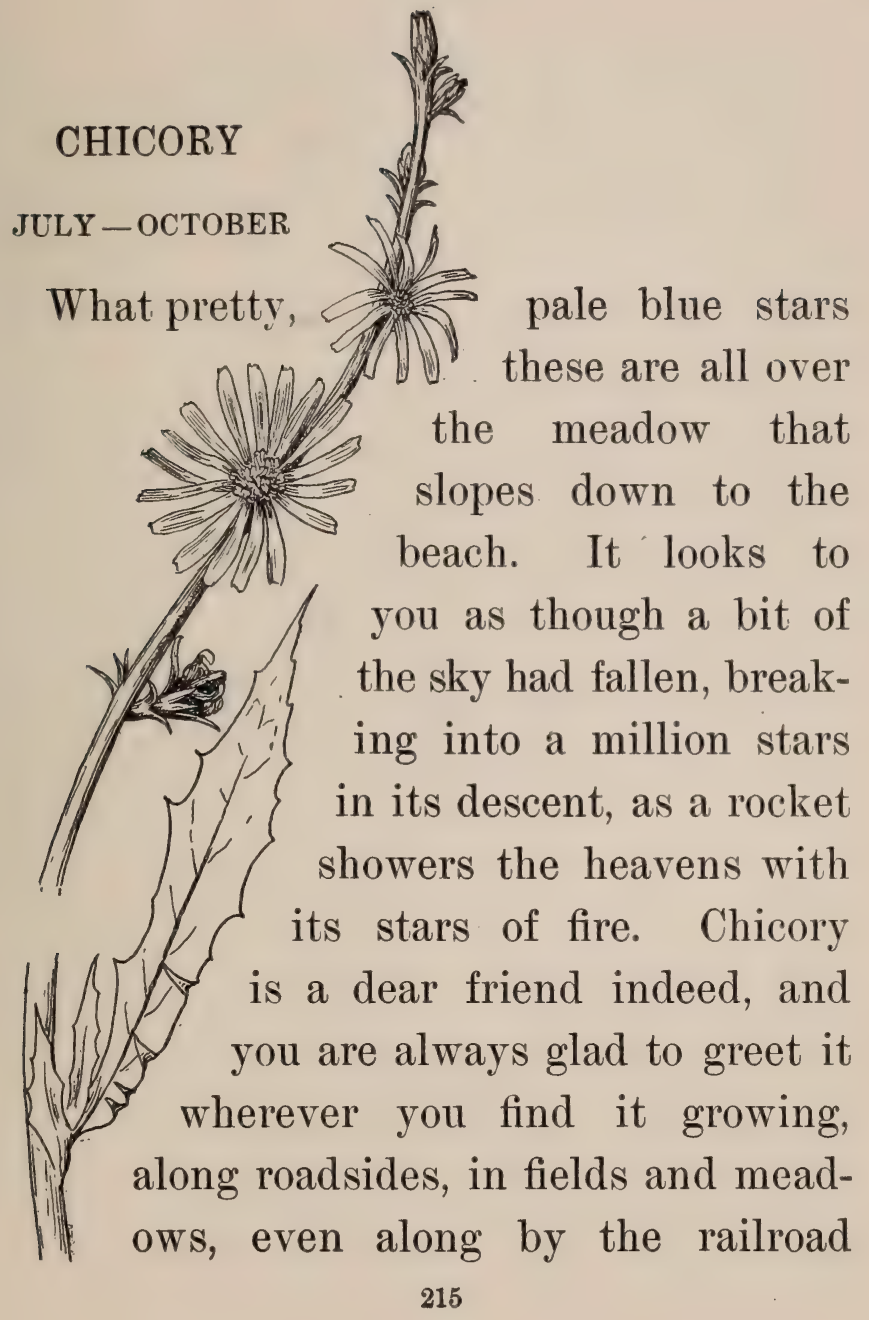


track, where the train whizzes you by so fast that the Chicory seems like shooting stars. Best of all, you love to find this friend in the little meadow by the beach, and all around the tiny cottage where you have spent delightful summers.

Close at hand is an old-fashioned garden, truly a wealth of beauty, each flower growing wherever it chooses to come up out of the ground - a happy tangle of flowers gorgeous to behold. Isn't it a delight to be allowed to walk among them, almost making your own path as you go, the original walks are so overgrown? Somehow, Chicory never quite gets into this garden, though it stands just outside the fence, where one can imagine it looking in wistfully at the gayety, and longing to join the happy party, but kept out by the stern hand of the garden's owner, 
who has a horror of "weeds." The flowers of Chicory are dear to you, though you wish they would not have such a "raggedy" way of growing on the stem, making it impossible to gather them into a respectable bouquet. Though your garden is not so splendid or fine as the neighboring one, you are very proud of your Goldenrod and Chicory, and even of the Burdock, from the burrs of which you can make such dear little chairs and tables for your dolls, though they have a most unpleasant way of sticking to one's clothes unless the utmost care is taken.

Once you found one of these burrs entangled in your hair, and you have never forgotten how hard it was to get out. 


\section{CARDINAL FLOWER}

Bellflower Family

Lobelia cardinalis

Lobelia Family (Gray)

\section{JULY - SEPTEMBER}

In moist soil. Stem slightly downy or nearly smooth, two to four and one-half feet high. The leaves are thin, wide, pointed at both ends, with edges cut into fine teeth; lower leaves with petioles, upper without. The flowers are in racemes, bright red. The lobes of the calyx are long and pointed. The corolla tube is long, twolipped, lobe on each side of the cleft erect or curved backwards, turned away from the other three, which are somewhat united. The stamens are free from corolla tube, but united into a tube or ring around the style. Three of the five anthers are usually larger than the other two. The stigma is two-lobed. 


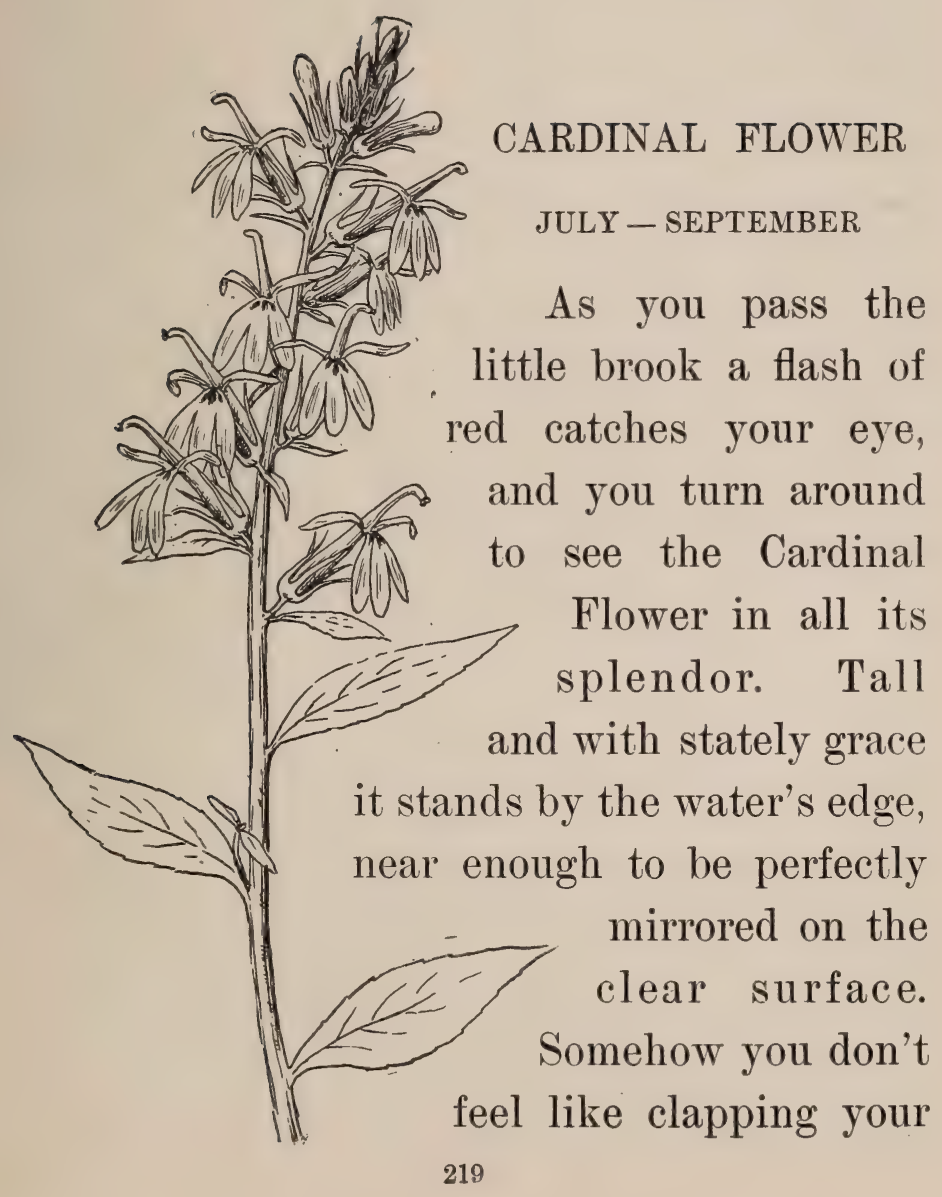


hands in its presence, but you catch your breath and stand drinking in the beauty of it. The brilliant flowers among the green rushes, with a background of trees in all shades of green, make a picture that you carry home in your mind, and see again after you are tucked into your little bed. You wonder why you remember these bright red flowers longer than any other of your flower friends. You really do not feel as well acquainted with them, - and yet the picture stays with you.

Do you remember the time that Father took you in a canoe up the little river, and you first had the opportunity to get very close to the splendid Cardinal Flowers? How delighted you were; but you hardly dared break one of the long stems. How wonderful the reflection was in the 


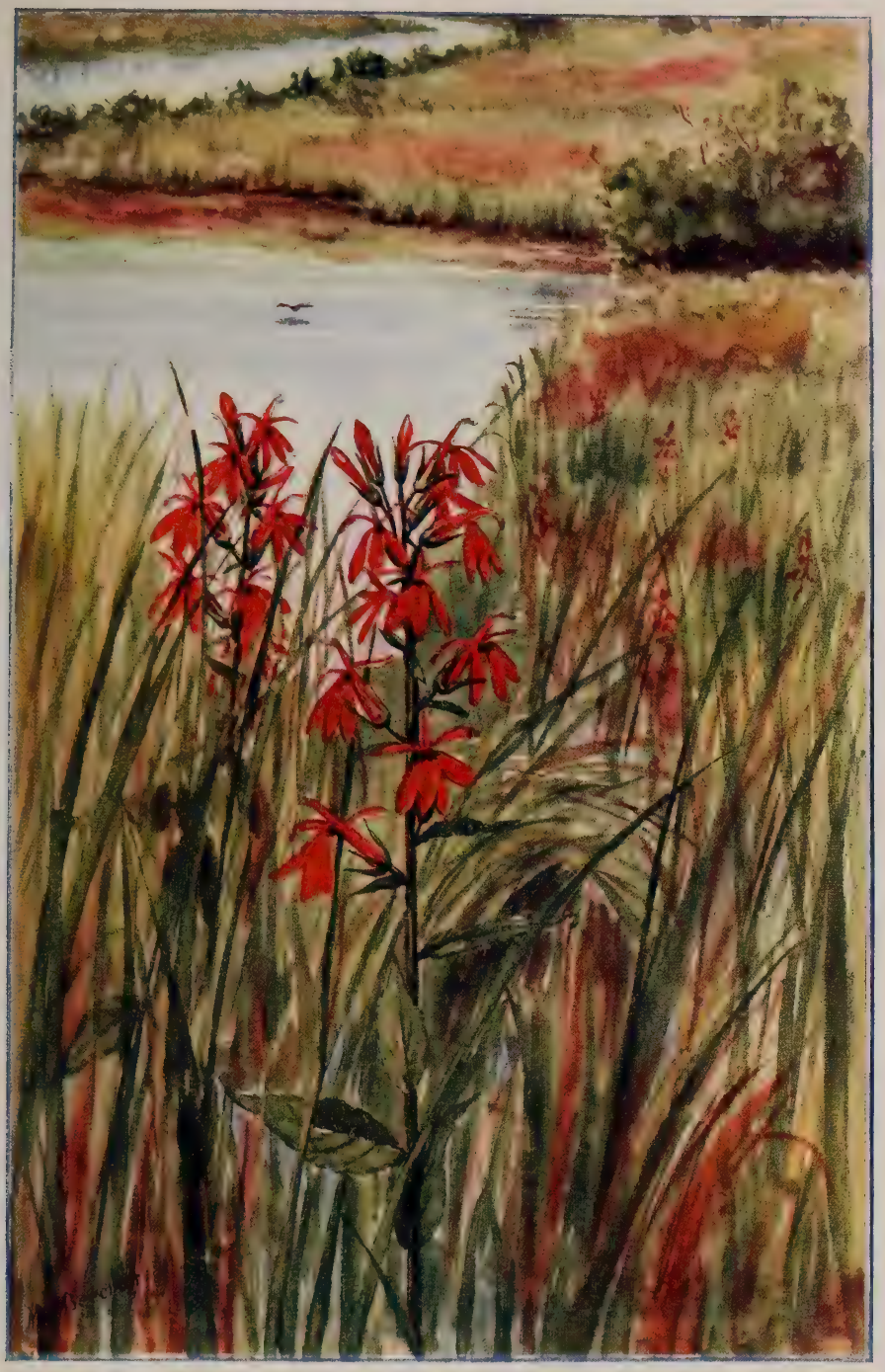

CARDINAL FLOWER 

river! The water looked very dark, almost black, with a greenish tinge where the trees were reflected, and the beautiful red flowers looking up at you were exactly like the ones on the shore.

Many flowers grow on one stem, so that each one is a charming mass of color. The flowers have five lobes to the corolla, two standing up like horns, and three hanging downwards, shaped something like your fingers. The Cardinal Flower belongs to the Bellflower Family, and has several relatives. One of them is called Venus' Looking Glass. Isn't that a pretty name? Would you like to find some of these flowers? 


\section{SWAMP ROSE MALLOW}

Mallow Family

Hibiscus Moscheutos

\section{AUGUST - SEPTEMBER}

IN brackish marshes and along rivers. Three to seven feet high, downy. The leaves are ovate, pointed, often three-lobed, downy underneath, but usually smooth on the top surface. The flower-stalks are slender. Flowers large, four to six inches broad, showy, rose-pink in color, with a darker centre sometimes. The calyx has five true sepals, with several bracts outside, looking like an outer calyx. The corolla consists of five petals. The stamens are numerous, on a tube which is connected with the base of the petals. The pistil has five branches of the style, with flat tops like pinheads. The pod is fivecelled, each cell many-seeded. 


\title{
SWAMP ROSE MALLOW
}

\author{
AUGUST - SEPTEMBER
}

The river was very still the morning that Father took you in the canoe away up

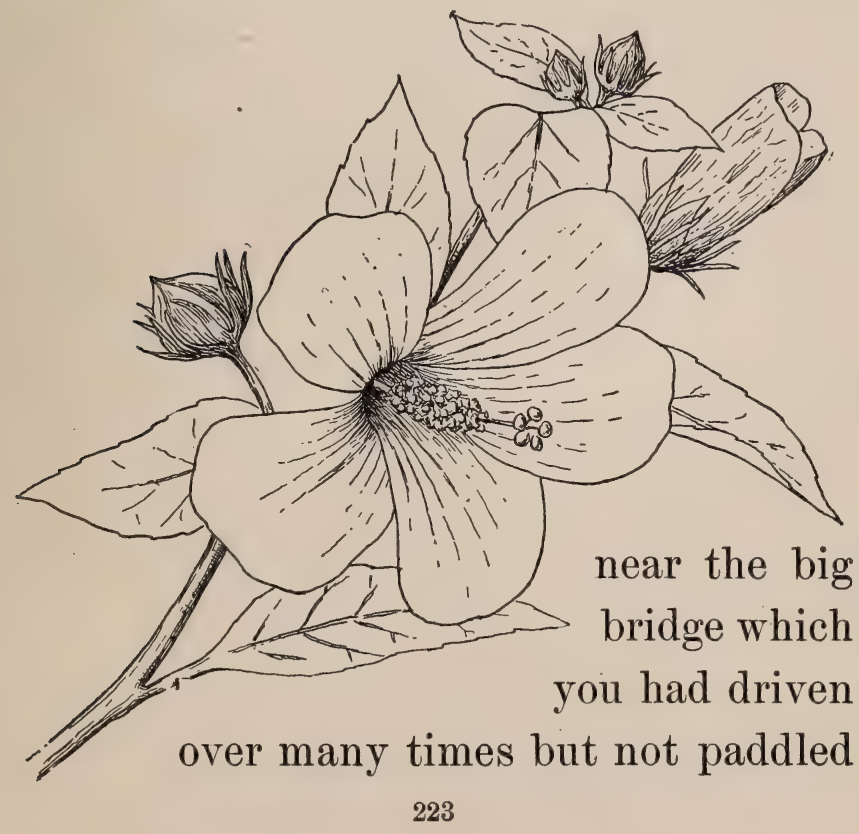


under. This day, joy of joys, Father let you take the paddle, and you had the most delightful time, sending the canoe first to one side, then the other. As you approached the bridge, you saw for the first time the beantiful pink blossoms of Swamp Rose Mallow towering up above the rushes just the other side of the bridge. You thought it was Hollyhock, and wondered who had planted a garden by the river, but Father told you it was Swamp Rose Mallow, a cousin of Hollyhock, and also of the Marsh Mallow that makes such delicious candy. What a treasure this was to find! In your eagerness and excitement you quite forgot how to paddle, and would have bumped into the bridge, and in all probability tumbled into the river, if Father had not been right there to guide the paddle. Soon you 
passed under the bridge, and found a good place for the canoe to stay while Father picked one or two of the beautiful blossoms for you. What a delight it was to hold them in your hands and drink in the beauty of color. You were much interested in the arrangement of stamens and pistils, like pins of different sizes stuck into a long cushion. The stigmas or tops of the pistils particularly, looked like flat pinheads, and they were much larger than the stamens. You counted five stigmas, but there were so many stamens that you could not count them, and soon gave up to enjoy the beauty of the whole flower. 


\section{JOE-PYE WEED}

Thistle Family

Composite Family (Gray)

Eupatorium purpureum

\section{AUGUST - SEPTEMBER}

Found in moist soil. Simple, or branched at top. The stem is green or purple, marked with grooves or stripes. The leaves are thin, petioled, toothed, whorled in threes or sixes. Flowerheads numerous, pink or purple. Involucre cylindric. The corolla is regular, with slender tube, its border, or limb, five-lobed, or fivetoothed. Anthers blunt and entire at base. Akenes are five-angled. Pappus of numerous hair-like bristles in one row. 


\section{JOE-PYE WEED}

\section{AUGUST - SEPTEMBER}

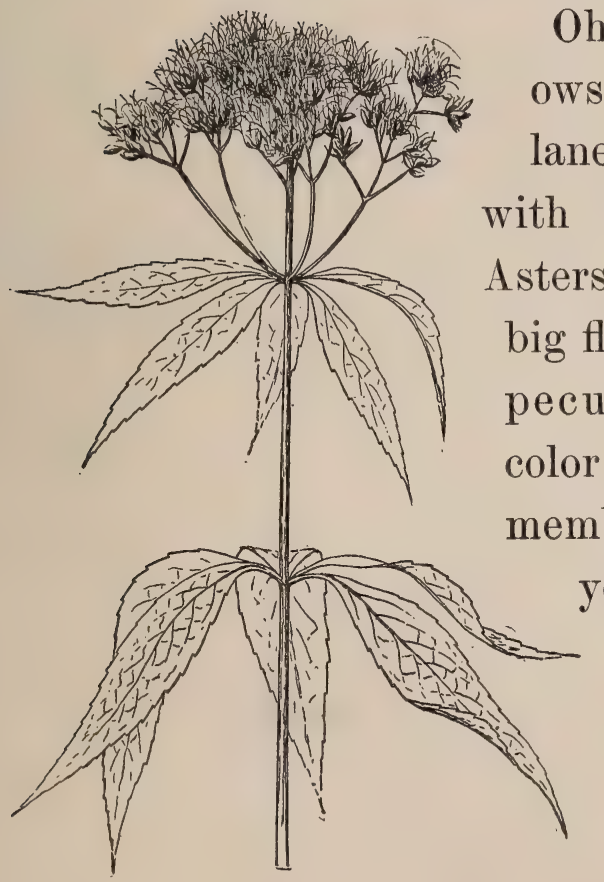

$\mathrm{Oh}$, the dear meadows, and the little lane just massed with Goldenrod and Asters, and sometimes big flower-heads of a peculiar purplish color! Do you remember how funny you thought it when Father told you their name was Joe Pye? You 
thought they must make very queer pie, and really wondered how people cooked them. How you learned to love their rough, ragged-looking heads, and how beautiful the meadows looked to you when they were bright with Goldenrod and Joe Pye in the late summer. Joe Pye never looked very friendly; you liked to see him in the fields better than in your hands with the dear Goldenrod and Asters, but you loved him just the same and watched for him.

He stands so very straight and stiff, even the wind hardly dares to move him. You learn that he is a cousin of the Goldenrods, and belongs to the great Composite or Thistle Family. $\mathrm{He}$ is a very independent fellow, and does not make friends as readily as some of his cousins. One would miss him from the 
landscape, though, and we are always glad to see him, like a sentinel guarding the meadows and roadsides.

If you look more closely at Joe Pye you will see that the flower-top is made up of many flowers in thick clusters at the end of branches almost like a little tree. This arrangement of flowers is called a Corymb, you remember, as you have found so many flowers grouped in the same way. 


\section{LADY'S TRESSES}

Orchug Family

Spiranthes cernua

Gyrostachys cernua

\section{AUGUST - OCTOBER}

Found in wet meadows and swamps. Leaves nearly from the base, long and narrow blade. Flowers white, fragrant, in thick twisted spike, in three rows. Side sepals free, upper arching, and connivent with petals, lip oblong or sometimes ovate, with broad tip crisped or scalloped into rounded teeth. Anther without a lid, on the back of the style. Ovate stigma on the front. There are two pollen-masses, each parted into two thin plates, their summits united to the back of a narrow, boat-shaped gland set in the beaked tip over the stigma. 


\section{LADY'S TRESSES \\ AUGUST - OCTOBER}

Close by the edge of a little pond you found these fragrant, exquisitely dainty flowers. How curiously they seemed to twist around the stem so that they looked as though they were on all sides of a braid of green. How you hunted all along the way for more, and what a pleasure it was to find one after another of these spikes of delicate white flowers!

It was a perfect day, the pond was beautiful in color, and your walk around the edge

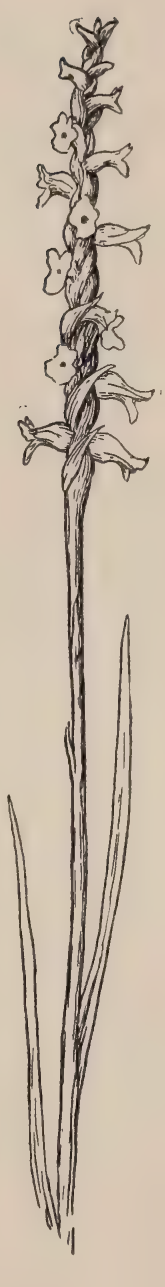


was a joy, rewarded with many precious finds, for numbers of your flower friends were there waiting to greet you, but none gave you more pleasure than this shy, delicate little Orchid that you came upon unexpectedly. You wondered why it was called Lady's Tresses, and were told that the original name was Lady's Traces, because of a fancied resemblance to the lacings called "traces" in the olden time. You like the name "tresses" better, and think it a good name, for does not the braid of flowers remind you of the tresses of a fairy princess? You imagine it the braid of Rapunzel, twined with flowers and let down from the high tower to form a ladder for the fairy prince, - and you think how delightful it would be if you could find a flower like this, tall enough and strong enough for you to climb up on 
to the top of the high water-tower, for you are sure that in there a fairy princess is hidden. Many times you have stood at the foot and wished for some way to reach the top so that you might see if it really was an enchanted tower. Sometimes when the wind blows you imagine you hear the voice of the princess singing, but she seems to be very quiet when the air is still. 


\section{LADY'S TRESSES}

When summer flowers have shut their sunny eyes,

And summer birds to summer lands are flown;

When crickets chant their drowsy monotone,

And sadly through the pines the south wind sighs ;

When over hill and plain in lavish tides The Goldenrod its garnered sunshine sheds,

And Asters, white and purple, nod their heads,

And seem to say, "Naught that is fair abides!"

$\mathrm{Ah}$, then in shady lane and grassy field, 
What new delight thy slender spires to find,

With tress of hyacinthine bells entwined! Fragrance like thine no rose of June can yield;

No Lily can eclipse thy snow, dear prize, Flung backward by sweet summer as she flies.

- Emilt Shaw Forman. 


\section{FRINGED GENTIAN}

Gentian Family

Gentiana Crinita

\section{SEPTEMBER - OCTOBER}

Found in low grounds. The stems are sometimes branching. Leaves are opposite, without leafstalks, lance-shaped or broader, with rounded or heart-shaped base. Flowers sky-blue, solitary on long flower-stalks. Calyx with four unequal lobes. Corolla funnel-form, with four wedge obovate lobes cut into delicate, long fringe at the margins. There are four stamens, opposite the lobes of the corolla, anthers straight. Pistil with a short style or none, two stigmas which remain after fruit is formed. The pod is oblong, containing innumerable small seeds. 


\section{FRINGED GENTIAN}

\section{SEPTEMBER - OCTOBER}

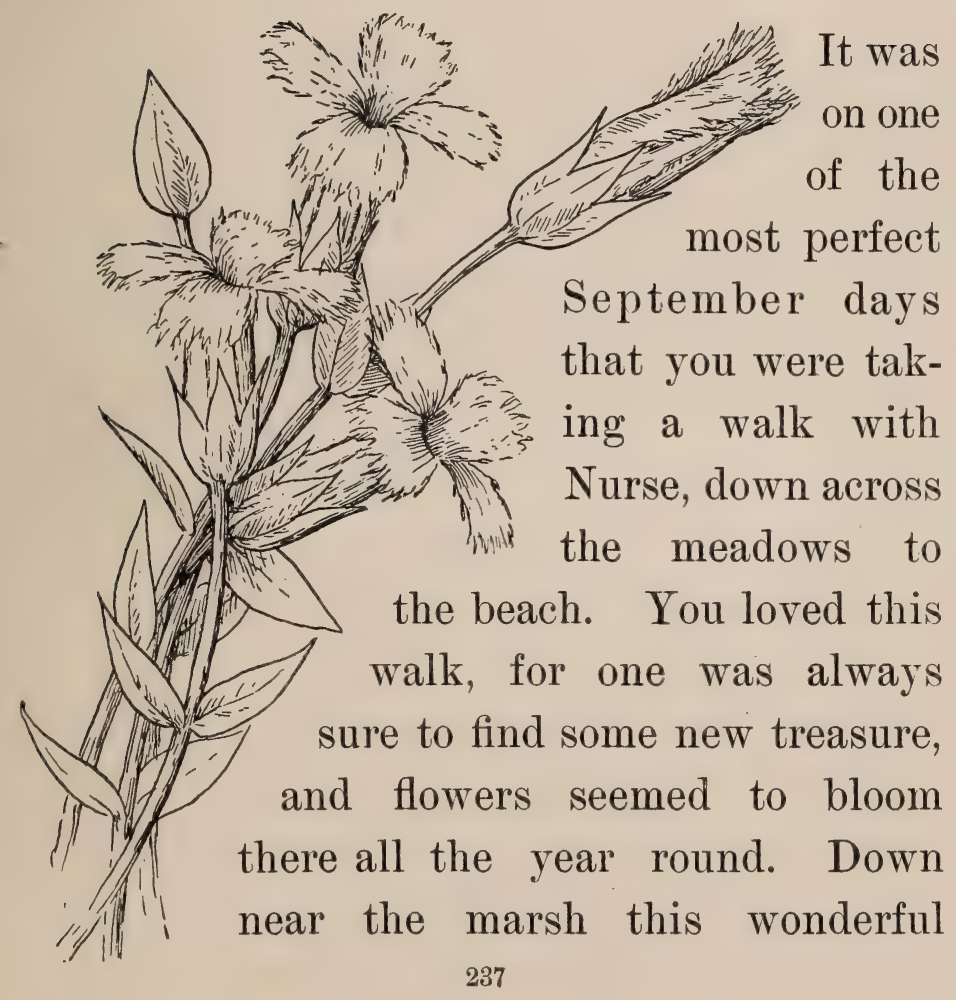


day you found the exquisite blue Gentian, each petal daintily fringed. What a beautiful bit of color, - your joy was beyond words, for you had never seen a flower before of such an intense blue, "heavenly blue" you called it. .You knew Gentian very well by name, for had not Mother often recited a poem to you about it which you loved to hear? Now, you had found the flowers for yourself, and it was a rare treat. With what eagerness you gathered a handful of the lovely blossoms to take home, and planned in your mind to come here every year in September to gather more. Mother told you, however, that Gentian was what might be called a wandering plant, because it does not bloom every year in the same place, and quite likely another year you would not find it at all down by the 


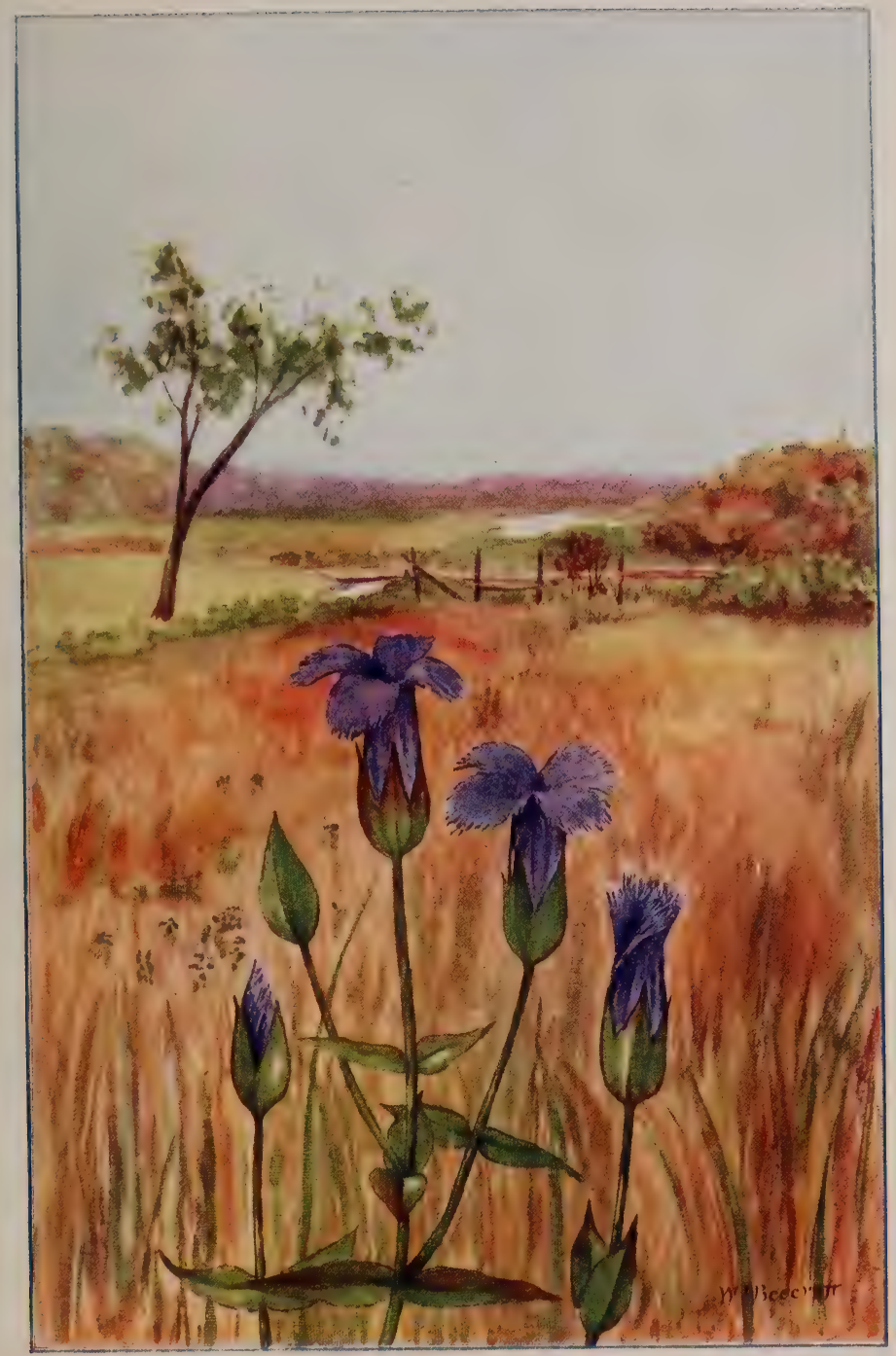

FRINGED GENTIAN 

marsh. You will always be glad to welcome it wherever you find it, and will look eagerly every year in the moist fields and meadows as you take your walks.

\section{THE FRINGED GENTIAN}

Thou blossom bright with autumn dew, And colored with the heaven's own blue, Thou openest when the quiet light Succeeds the keen and frosty night.

Thou comest not when Violets lean O'er wandering brooks and springs unseen,

Or Columbines in purple dressed Nod o'er the ground-bird's hidden nest.

Thou waitest late and com'st alone, When woods are bare and birds are flown, 
And the frosts and shortening days portend

The aged year is near his end.

Then doth thy sweet and quiet eye Look through its fringes to the sky, Blue - blue - as if that sky let fall A flower from its cerulean wall.

I would that thus, when I shall see The hour of death draw near to me, Hope, blossoming within my heart, May look to heaven as I depart.

- William Cullen Bryant. 



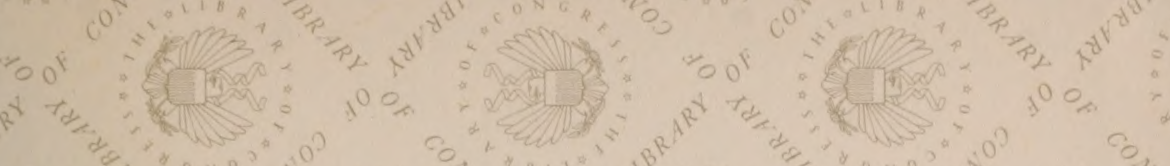

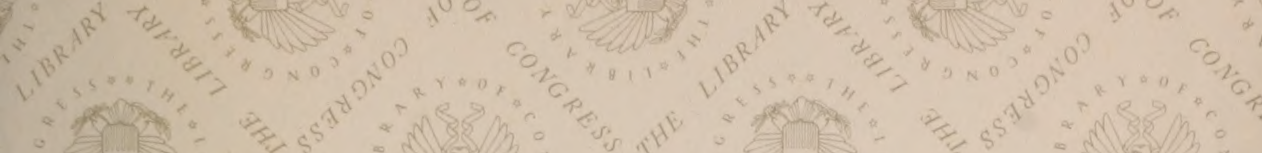

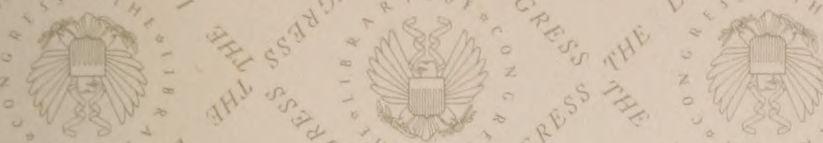

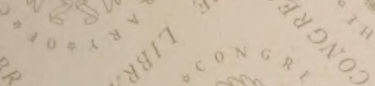

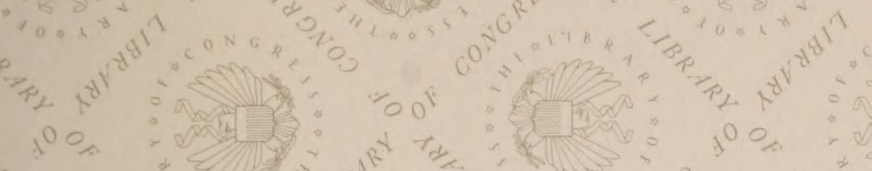

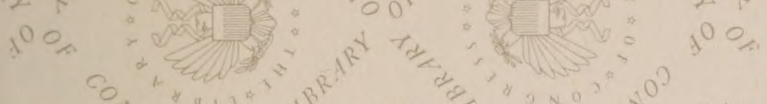

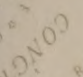

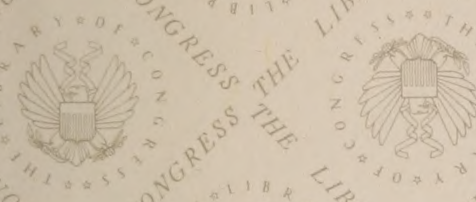
${ }^{4}{ }^{4}{ }_{0}$

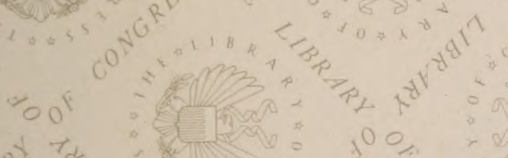

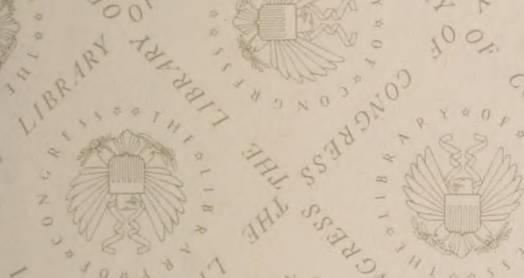

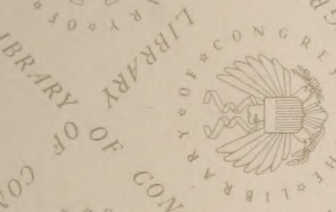
$\% 00$

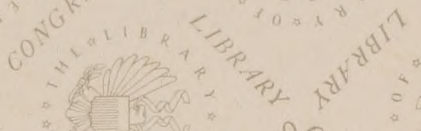

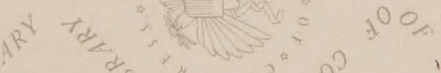

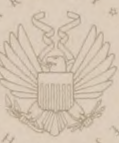<smiles>C#CC1CCCCC1CCC</smiles>
N. $26 \operatorname{los}^{4}$ 
LIBRARY OF CONGRESS

MNAM

00053455256 